\title{
Foundation Heat Exchanger Final Report: Demonstration, Measured Performance, and Validated Model and Design Tool
}

\author{
January 2012
}

Revised January 2013

Prepared by

Patrick Hughes

Piljae Im

Energy and Transportation Science Division

Sponsored by

Building Technologies Program

U.S. Department of Energy

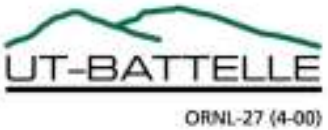




\title{
DOCUMENT AVAILABILITY
}

Reports produced after January 1, 1996, are generally available free via the U.S. Department of Energy (DOE) Information Bridge.

Web site http://www.osti.gov/bridge

Reports produced before January 1, 1996, may be purchased by members of the public from the following source.

\author{
National Technical Information Service \\ 5285 Port Royal Road \\ Springfield, VA 22161 \\ Telephone 703-605-6000 (1-800-553-6847) \\ TDD 703-487-4639 \\ Fax 703-605-6900 \\ E-mail info@ntis.gov \\ Web site http://www.ntis.gov/support/ordernowabout.htm
}

Reports are available to DOE employees, DOE contractors, Energy Technology Data Exchange (ETDE) representatives, and International Nuclear Information System (INIS) representatives from the following source.

Office of Scientific and Technical Information

P.O. Box 62

Oak Ridge, TN 37831

Telephone 865-576-8401

Fax 865-576-5728

E-mail reports@osti.gov

Web site http://www.osti.gov/contact.html

This report was prepared as an account of work sponsored by an agency of the United States Government. Neither the United States Government nor any agency thereof, nor any of their employees, makes any warranty, express or implied, or assumes any legal liability or responsibility for the accuracy, completeness, or usefulness of any information, apparatus, product, or process disclosed, or represents that its use would not infringe privately owned rights. Reference herein to any specific commercial product, process, or service by trade name, trademark, manufacturer, or otherwise, does not necessarily constitute or imply its endorsement, recommendation, or favoring by the United States Government or any agency thereof. The views and opinions of authors expressed herein do not necessarily state or reflect those of the United States Government or any agency thereof. 
FOUNDATION HEAT EXCHANGER FINAL REPORT:

DEMONSTRATION, MEASURED PERFORMANCE, AND VALIDATED MODEL AND DESIGN TOOL

\author{
Patrick Hughes \\ Piljae Im \\ Date Published: January 2012 \\ Revised: January 2013 \\ Prepared by \\ OAK RIDGE NATIONAL LABORATORY \\ Oak Ridge, Tennessee 37831-6283 \\ managed by \\ UT-BATTELLE, LLC \\ for the \\ U.S. DEPARTMENT OF ENERGY \\ under contract DE-AC05-00OR22725
}





\section{CONTENTS}

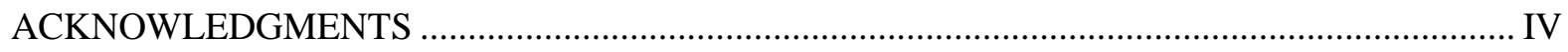

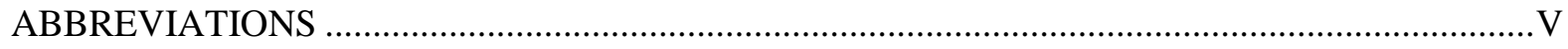

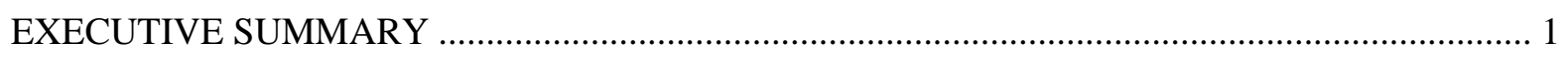

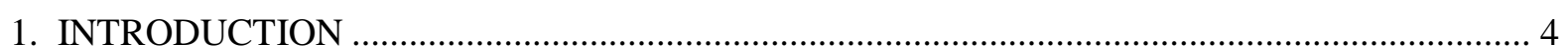

2. FIELD TEST OF THE FOUNDATION HEAT EXCHANGER CONCEPT ............................... 7

2.1 Field Test of FHX — One of Many Experiments in the First ZEBRAlliance Project ............... 7

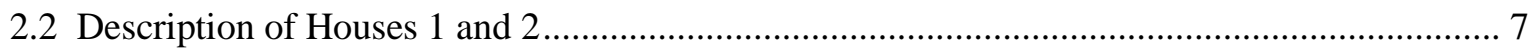

2.3 Description of Ground Heat Exchangers Installed in Houses 1 and 2 .................................. 11

2.4 Ground Heat Exchanger Performance Measurements ........................................................ 18

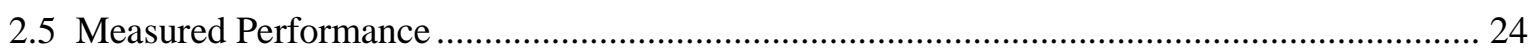

3. NUMERICAL MODEL AND DESIGN TOOL DEVELOPMENT AND VALIDATION ............ 32

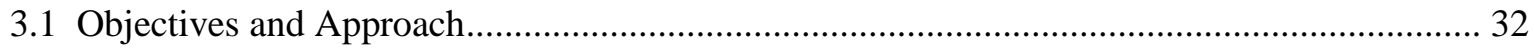

3.2 Research-Grade, 2-Dimensional, Fine-Grid, Finite-Volume, FHX Model ............................ 33

3.3 Research-Grade, Multi-Block, Boundary-Fitted, 3-Dimensional, Finite-Volume, FHX

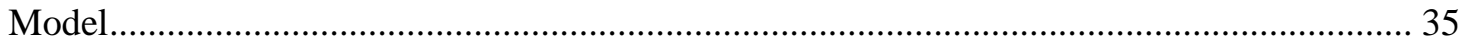

3.4 Computationally Efficient, 3-Dimensional, Dual-Coordinate-system, Finite-Volume,

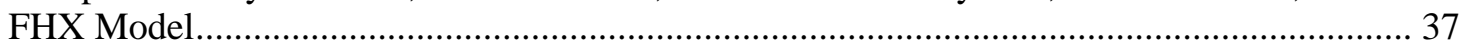

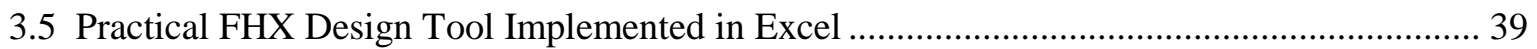

3.6 Geographic Range of Feasibility of GSHP Systems Using FHX in the United States............ 41

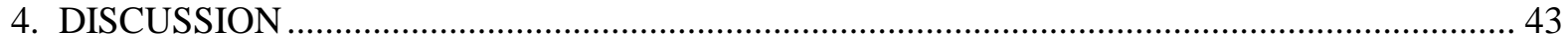

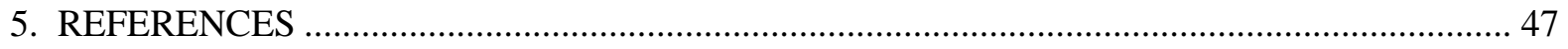

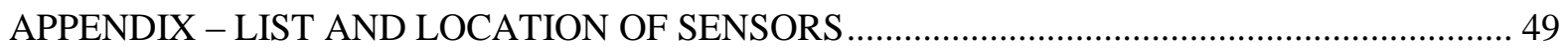




\section{ACKNOWLEDGMENTS}

This report and the work described were sponsored by the Building Technologies Program of the U.S. Department of Energy's Office of Energy Efficiency and Renewable Energy and the Tennessee Valley Authority.

The authors wish especially to acknowledge the contributions of Schaad Companies, which acquired the land and built the test houses for this research at their own expense, and leased them to ORNL for \$1 per month for the duration of the project. Without Schaad Companies this research project (and many others utilizing a total of four test houses) would not have been possible. In addition, ClimateMaster, Inc. donated the water-source heat pumps installed in the test houses and used in the research reported here. This and other research projects, reliant upon the same test houses but not the subject of this report, also benefited from contributions of materials and expertise made by additional industry partners of Oak Ridge National Laboratory, as acknowledged at www.zebralliance.com. ZEBRAlliance - a public-private partnership to maximize cost-effective energy efficiency in buildings — was co-founded by ORNL and Schaad Companies in 2008. 


\section{ABBREVIATIONS}

2D Two dimensional

3D Three dimensional

ACCA Air Conditioning Contractors of America

ACH Air changes per hour

ASHRAE American Society of Heating, Refrigerating and Air-Conditioning Engineers

CAD

COP

DCS

DOE

DTN

EER

EFT

Computer-aided design

Coefficient of performance

Dual-coordinate system

U.S. Department of Energy

Dynamic thermal network

Energy efficiency ratio

ERV

EWT

Entering fluid temperature

FHX

Energy recovery ventilator

FHX

Entering water temperature

GSHP

Foundation heat exchanger

HERS

Ground source heat pump

HGHX

Home Energy Rating System

$\mathrm{HI}$

Horizontal ground heat exchanger

IECC

LFT

LWT

OA

High insulation

OAT

International Energy Conservation Code

ORNL

OSB

OSU

OVF

Leaving fluid temperature

Leaving water temperature

Outdoor air

Outdoor air temperature

SIP

VBA

VHI

Oak Ridge National Laboratory

Oriented strand board

Oklahoma State University

Optimal value framing

WAHP

Structural insulated panel

WWHP

Visual Basic for Applications

Very high insulation

Water to air heat pump

Water to water heat pump 


\section{EXECUTIVE SUMMARY}

Geothermal heat pumps, sometimes called ground-source heat pumps (GSHPs), have been proven capable of significantly reducing energy use and peak demand in buildings. Conventional equipment for controlling the temperature and humidity of a building, or supplying hot water and fresh outdoor air, must exchange energy (or heat) with the building's outdoor environment. Equipment using the ground as a heat source and heat sink consumes less non-renewable energy (electricity and fossil fuels) because the earth is cooler than outdoor air in summer and warmer in winter. The most important barrier to rapid growth of the GSHP industry is high first cost of GSHP systems to consumers.

The most common GSHP system utilizes a closed-loop ground heat exchanger. This type of GSHP system can be used almost anywhere. There is reason to believe that reducing the cost of closed-loop systems is the strategy that would achieve the greatest energy savings with GSHP technology. The cost premium of closed-loop GSHP systems over conventional space conditioning and water heating systems is primarily associated with drilling boreholes or excavating trenches, installing vertical or horizontal ground heat exchangers, and backfilling the excavations.

This project investigates reducing the cost of horizontal closed-loop ground heat exchangers by installing them in the construction excavations, augmented when necessary with additional trenches. This approach applies only to new construction of residential and light commercial buildings or additions to such buildings. In the business-as-usual scenario, construction excavations are not used for the horizontal ground heat exchanger (HGHX); instead the HGHX is installed entirely in trenches dug specifically for that purpose. The potential cost savings comes from using the construction excavations for the installation of ground heat exchangers, thereby minimizing the need and expense of digging additional trenches.

The term foundation heat exchanger (FHX) has been coined to refer exclusively to ground heat exchangers installed in the overcut around the basement walls. The primary technical challenge undertaken by this project was the development and validation of energy performance models and design tools for FHX. In terms of performance modeling and design, ground heat exchangers in other construction excavations (e.g., utility trenches) are no different from conventional HGHX, and models and design tools for HGHX already exist.

This project successfully developed and validated energy performance models and design tools so that FHX or hybrid FHX/HGHX systems can be engineered with confidence, enabling this technology to be applied in residential and light commercial buildings. The validated energy performance model also addresses and solves another problem, the longstanding inadequacy in the way ground-building thermal interaction is represented in building energy models, whether or not there is a ground heat exchanger nearby.

Two side-by-side, three-level, unoccupied research houses with walkout basements, identical 3,700 $\mathrm{ft}^{2}$ floor plans, and hybrid FHX/HGHX systems were constructed to provide validation data sets for the energy performance model and design tool. The envelopes of both houses are very energy efficient and airtight, and the HERS ratings of the homes are 44 and 45 respectively. Both houses are mechanically ventilated with energy recovery ventilators, with space conditioning provided by water-to-air heat pumps with 2 ton nominal capacities. Separate water-to-water heat pumps with 1.5 ton nominal capacities were used for water heating. In these unoccupied research houses, human impact on energy use (hot water draw, etc.) is simulated to match the national average.

At House 1 the hybrid FHX/HGHX system was installed in 300 linear feet of excavation, and 60\% of that was construction excavation (needed to construct the home). At House 2 the hybrid FHX/HGHX system was installed in 360 feet of excavation, 50\% of which was construction excavation. There are six pipes in 
all excavations (three parallel circuits - out and back), and the multiple instances of FHX and/or HGHX are all connected in series. The working fluid is $20 \%$ by weight propylene glycol in water.

Model and design tool development was undertaken in parallel with constructing the houses, installing instrumentation, and monitoring performance for a year. Several detailed numerical models for FHX were developed as part of the project. Essentially the project team was searching for an energy performance model accurate enough to achieve project objectives while also having sufficient computational efficiency for practical use in EnergyPlus. A 3-dimensional, dual-coordinate-system, finite-volume model satisfied these criteria and was included in the October 2011 EnergyPlus Version 7 public release after being validated against measured data. EnergyPlus using this model can complete an annual simulation of an FHX thermally coupled to a basement in less than two minutes on a standard desktop computer.

A practical design tool for sizing pure FHX or hybrid FHX/HGHX systems was also developed and implemented in Excel using Visual Basic for Applications. Using the design tool, sizing the FHX or FHX/HGHX for a residential application can be accomplished in about five minutes. Compared to one of the numerical models, the design tool was found to oversize the ground heat exchanger by 17 to $20 \%$ in five of six benchmarking locations, and by $29 \%$ in the remaining location. The design tool oversized the hybrid FHX/HGHX system at House 1 by $23 \%$. Given the inherent uncertainties in design inputs such as building loads and soil thermal properties, this level of accuracy in a simplified FHX design method is acceptable.

One of the numerical models was used to investigate the geographical range of technical feasibility of FHX systems. Preliminary analysis indicated that pure FHX systems are technically feasible for new construction in nearly half the United States. Although not investigated, hybrid FHX/HGHX systems using all available construction excavations should have some level of installed cost savings over conventional HGHX systems in almost any residential or light commercial new construction project involving significant excavation. Since FHX and hybrid FHX/HGHX ground heat exchangers are designed to maintain the same operating temperature range as conventional ground heat exchangers, the energy-savings performance of the GSHP system is the same regardless, making cost reduction the primary goal.

Preliminary estimates indicate that when implemented at scale by a production builder, ground heat exchanger in construction excavations (FHX in overcut around basement or HGHX in utility trenches) may be feasible at $\$ 1,000$ per ton. That compares with traditional vertical-loop and six-pipe-per-virgintrench HGHX systems that typically are installed in East Tennessee at $\$ 3,000$ per ton and $\$ 2,250$ per ton, respectively. If these values are correct, hybrid systems would warrant consideration even when use of construction excavations exclusively is not feasible. For example, a 3-ton hybrid FHX/HGHX ground heat exchanger application where construction excavations are adequate for two-thirds of the load would cost $\$ 4,250(2 \times \$ 1000+\$ 2,250)$ compared to $\$ 6,750$ (3 x $\$ 2,250)$ for pure HGHX in virgin trench. The actual cost of a particular project may vary depending on drilling/trenching conditions, regional cost variations, underground soil thermal properties and building geometry. Whether cost reductions through use of construction excavations are enough for GSHP systems to gain significantly broader consideration in new construction markets remains to be seen. The authors recommend several next steps to find out. 


\section{INTRODUCTION}

Geothermal heat pumps, sometimes called ground-source heat pumps (GSHPs), have been proven capable of significantly reducing energy use and peak demand in buildings. Conventional equipment for controlling the temperature and humidity of a building, or supplying hot water and fresh outdoor air, must exchange energy (or heat) with the building's outdoor environment. Equipment using the ground as a heat source and heat sink consumes less non-renewable energy (electricity and fossil fuels) because the earth is cooler than outdoor air in summer and warmer in winter. Heat pumps are always used in GSHP systems. They efficiently move heat from ground energy sources or to ground heat sinks as needed. Although heat pumps consume electrical energy, they move 3 to 5 times as much energy between the building and the ground than they consume while doing so.

Policy makers are seeking clean energy technology options that can be deployed with speed and scale to provide large reductions in building energy use. The most important barrier to rapid growth of the GSHP industry is high first cost of GSHP systems to consumers (Hughes 2008). The most common GSHP system utilizes a closed-loop ground heat exchanger. This type of GSHP system can be used almost anywhere, regardless of the availability or suitability of nearby surface water, gray water, effluent, storm water, rainwater, or groundwater. Since the number of GSHP systems installed can have a dramatic impact on first cost to consumers (shipment volume begets affordability), there is reason to believe that reducing the cost of closed-loop systems is the strategy that would achieve the greatest energy savings with GSHP technology. The cost premium of closed-loop GSHP systems over conventional space conditioning and water heating systems is primarily associated with drilling boreholes or excavating trenches, installing vertical or horizontal ground heat exchangers, and backfilling the excavations.

In general, the length of the bore or excavation needed for a given building is a function of the building's space conditioning and water heating loads. Minimizing those loads minimizes the ground heat exchanger size and the excavation needed for its installation. In the case of extremely energy efficient homes and light commercial buildings, space conditioning and water heating loads may be so low that the excavations required to construct the buildings provide sufficient space by themselves for the entire length of ground heat exchanger. But even when insufficient for the entire ground heat exchanger, using the construction excavations minimizes the need for additional trenching and reduces costs. The construction excavations are already bought and paid for - why not use them for double duty?

This project investigates reducing the cost of horizontal closed-loop ground heat exchangers by installing them in the construction excavations, augmented when necessary with additional trenches. In general, construction excavations may include the overcut around the basement walls, below the basement floor, utility trenches (for buried water, sewer, and power), and trenches for draining the foundation footers. The term foundation heat exchanger (FHX) has been coined to refer exclusively to ground heat exchangers installed in the overcut around basement walls. The primary technical challenge undertaken by this project was the development and validation of energy models and design tools for FHX. In terms of performance modeling and design, ground heat exchangers in utility and footer drain trenches are no different from conventional horizontal ground heat exchangers (HGHX), and models and design tools for HGHX already exist. When trenches are used for double duty, adequate spacing is of course required (e.g., between buried water lines and heat exchanger loops), but simple guidance on this issue is expected to suffice.

Ground heat exchangers installed below the basement floor are not addressed in this report. Project resources were insufficient to address both FHX and sub-floor systems, and it was important to tackle the greatest technical challenge first. Since the sub-floor case has very simple geometry and boundary conditions, the project team felt confident that this capability could be added to the models and design 
tools later. As it turned out, the computationally efficient performance model developed by this project is able to model sub-floor systems, although this capability has not yet been validated against measured data.

A previous project successfully demonstrated that a GSHP system using construction excavations was feasible for a specific, small, ultra-high-energy-efficiency house in one climate (Christian and Bonar 2008). The project documented in this report developed and validated performance models and design tools so that FHX or hybrid FHX/HGHX systems can be engineered with confidence, hence enabling the technology to be applied on a large scale.

In this day of scarce research and development resources, it is always important to design research projects to solve multiple problems wherever possible. Another problem addressed and solved here is the longstanding inadequacy in the way ground-building thermal interaction is represented in building energy models. Today's flagship building energy models (DOE-2, EnergyPlus, etc.) were originally designed with large commercial buildings in mind, and it is understandable that not much attention was paid to ground-building thermal interaction. Compared to many other large building characteristics at the time, this feature had only a small influence on predicted building energy consumption. Recently, however, there has been much greater emphasis on using energy models as an integrated whole-building design tool, and mandatory energy codes and voluntary rating systems are driving higher levels of building energy efficiency. In addition, usability of these models has improved, and their use in light commercial and even residential projects is growing - hence ground-building thermal interaction is no longer negligible. The numerical models developed by this project accurately characterize ground-building thermal interaction, whether or not there is a ground heat exchanger nearby.

Oak Ridge National Laboratory (ORNL) assembled a team for the project that included Schaad Companies, one of the largest home builders in East Tennessee, and a team led by Dr. Jeff Spitler of Oklahoma State University (OSU) and including Dr. Simon Rees (De Montfort University, United Kingdom) and several post-graduate students. ORNL provided the overall project management during the multi-year effort. ORNL's role included providing Schaad Companies with technical expertise and access to ORNL's industry partners during the design and construction of two test homes having GSHP systems using hybrid FHX/HGHX, developing the FHX/HGHX test plan, installing the instrumentation, collecting and analyzing performance data, defining the technical scope of work for the OSU subcontract, managing the OSU subcontract, and authoring this final report. ORNL's research effort was sponsored by the U.S. Department of Energy (DOE) Building Technologies Program and Tennessee Valley Authority.

Schaad Companies (schaadcompanies.com), ORNL's founding partner in ZEBRAlliance — a publicprivate partnership to maximize cost-effective energy efficiency in buildings (zebralliance.com) - has built four energy-efficient test houses in the Crossroads at Wolf Creek Subdivision in Oak Ridge, Tennessee. Schaad Companies acquired the land and built the test houses at their own expense, and leased them for \$1 per month each to ORNL for research purposes for 30 months. Houses 1 and 2, which were used for the FHX research, are three-level homes with walkout basements. Houses 1 and 2 were completed in November 2009 and data collection began in December.

OSU's relationship to ORNL was that of a research subcontractor. The funding for the OSU subcontract was provided to ORNL by the DOE Building Technologies Program. OSU engaged De Montfort University through a sub-tier agreement. The role of the OSU team was to develop (1) a research-grade, 2-dimensional, fine-grid, finite-volume FHX energy model in HVACSIM+, (2) a research-grade, multiblock, boundary-fitted, 3-dimensional, finite-volume FHX energy model in EnergyPlus, (3) a computationally efficient, 3-dimensional, dual-coordinate-system, finite-volume, FHX energy model in EnergyPlus, and (4) a practical FHX and hybrid FHX/HGHX design tool implemented in Excel using Visual Basic for Applications (VBA). The OSU role also included using the measured data from the test house provided by ORNL to validate the various FHX energy models and the practical design tool, 
integrating a validated FHX model into a whole-building energy simulation of a single-family residence, and using simulation to explore the geographic range of feasibility of GSHP systems using pure FHX ground heat exchangers in single-family residences in the United States.

This report documents the overall project in a brief and easily readable format and cites other publications where the project's technical work is documented in great detail. In the special case of the test house field data acquisition and analysis, the detailed documentation is included in the body and appendices of this report since it exists nowhere else. 


\section{FIELD TEST OF THE FOUNDATION HEAT EXCHANGER CONCEPT}

\subsection{Field Test of FHX — One of Many Experiments in the First ZEBRAlliance Project}

ORNL and Schaad Companies founded the ZEBRAlliance in August 2008 through Memorandum of Agreement MOA-UTB-2008037 and a separate alliance agreement. ZEBRAlliance is a public-private partnership to maximize the cost-effective energy efficiency of buildings. As part of the first ZEBRAlliance project, Schaad Companies built four energy-efficient test houses in the Crossroads at Wolf Creek Subdivision in Oak Ridge, Tennessee. Schaad Companies acquired the land and built the test houses at their own expense, and leased them for \$1 per month each to ORNL for research purposes for 30 months. Another member of the alliance, BarberMcMurry Architects, donated their time to design the test houses. More than 30 ORNL industry partners became alliance members and donated their most advanced energy efficiency products for use in the construction. The four ZEBRAlliance test houses are being used for many different experiments. For more information, visit www.zebralliance.com.

\subsection{Description of Houses 1 and 2}

The side-by-side research houses, House 1 and House 2, have identical 3,700 $\mathrm{ft}^{2}$ floor plans. In these unoccupied research houses, human impact on energy use is simulated to match the national average, with showers, lights, ovens, washers, and other energy-consuming equipment turned on and off at exactly the same times. Simulating occupancy eliminates a major source of uncertainty in whole-house energy consumption, enabling valid side-by-side experiments even when each "case" has a sample size of one.

The primary experiment using houses 1 and 2 involved testing two different envelope strategies - a structural insulated panel (SIP) envelope in House 1, and an Optimal Value Framing (OVF) envelope in House 2. As implemented, both of these strategies had very low air leakage and high levels of insulation, and thus have very low heat gain and loss through the building envelope, which of course contributes to their very low space conditioning loads. In short, they are exactly the type of homes where it should be feasible to install a large portion of the ground heat exchanger in construction excavations. Figures 2.1 and 2.2 show front and rear views of the houses.

The ground heat exchangers in houses 1 and 2 (described in Section 2.3) were intentionally similar to provide experimental redundancy, essentially guaranteeing that experimental data would be available to validate the models and design tools described in Chapter 3. Validation was based on the House 1 data set for reasons explained later.

The envelope characteristics of House 1 and House 2 are described in detail in Miller et al. 2010. Summary descriptions of the building envelope subsystems are provided in Table 2.1. It should be noted that the basement walls are poured concrete with a polymer-enhanced asphalt membrane spray-applied to the outside for waterproofing. Fiberglass $2 \frac{3}{8} \mathrm{in}$. drainage board is placed against and adhered to the asphalt membrane. The drainage board serves dual purposes of insulating the outside of the basement wall and acting as a drainage plane to enable rainwater to seep to the footer drains. 


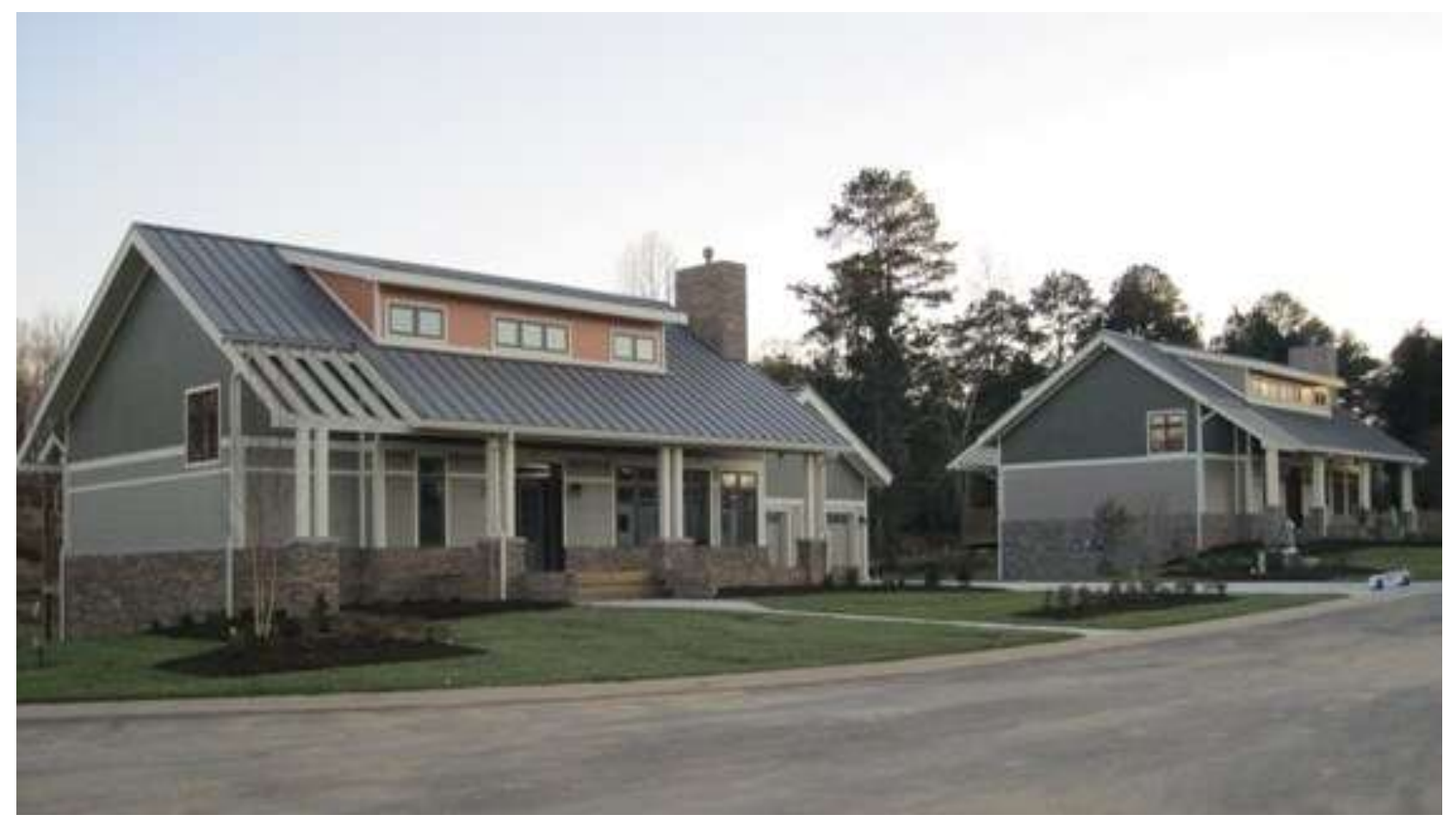

Figure 2.1. Front view of House 1 (right) and House 2 (left) from the street.

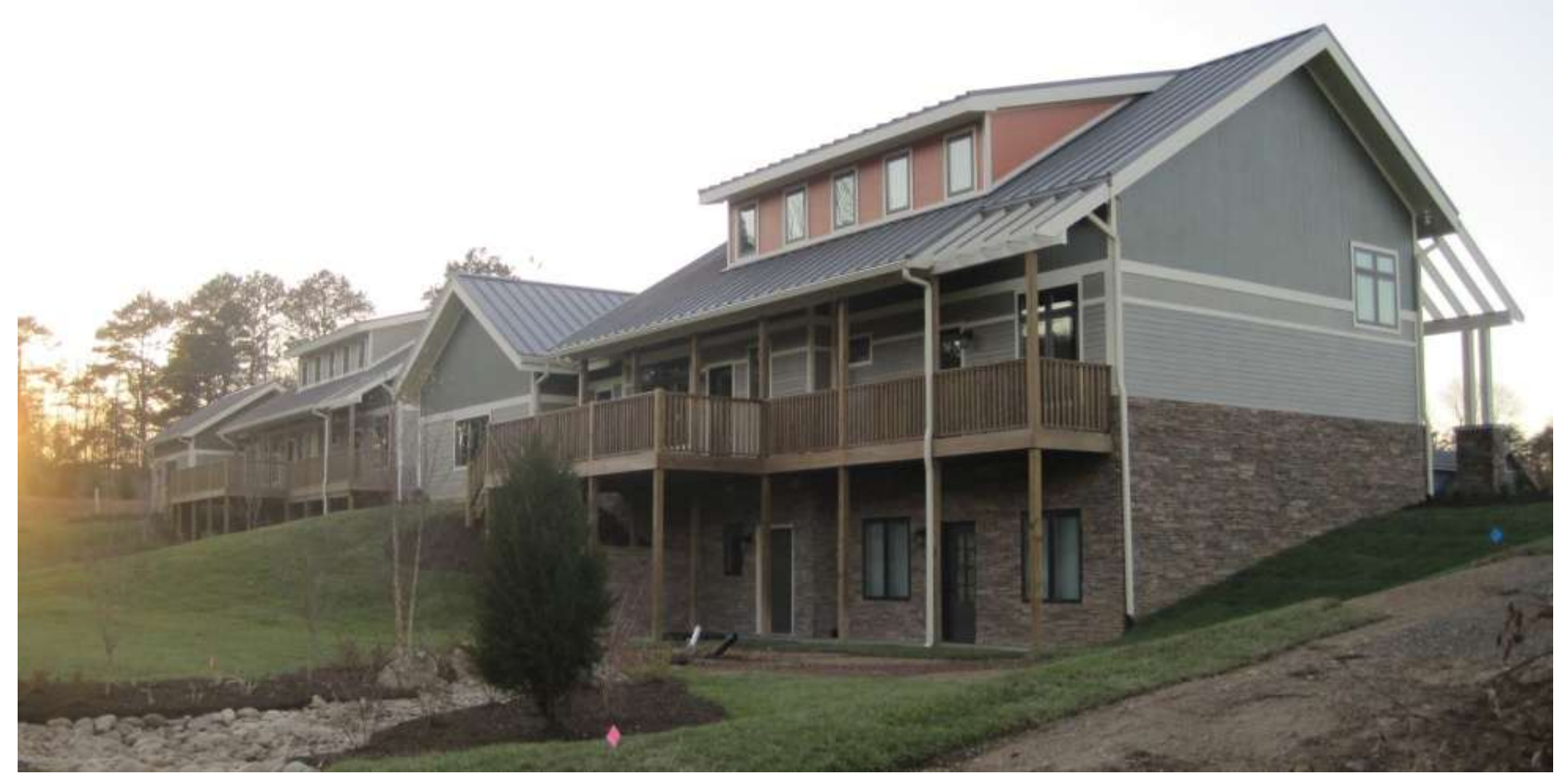

Figure 2.2. Rear view of House 1 (left) and House 2 (right) showing the walkout basements. 
Table 2.1. Description of House 1 and House 2 building envelope subsystems

\begin{tabular}{|c|c|c|}
\hline Envelope component & $\begin{array}{c}\text { House } 1 \\
\text { Structural Insulated Panel } \\
\text { Strategy }\end{array}$ & $\begin{array}{c}\text { House } 2 \\
\text { Optimal Value Framing } \\
\text { Strategy }\end{array}$ \\
\hline Roof & IRR standing seam metal & IRR standing seam metal \\
\hline Roof deck & SIPS & $\begin{array}{l}\text { Foil facing on } \\
\text { phenolic foam }\end{array}$ \\
\hline Roof deck ventilation & $\begin{array}{l}\text { Open at eave and ridge above } \\
\text { sheathing }\end{array}$ & $\begin{array}{c}\text { Open at soffit and ridge below } \\
\text { sheathing }\end{array}$ \\
\hline Sheathing & DELTA®-TRELA & Felt paper \\
\hline Attic & $\begin{array}{c}\text { R-35 } \\
\text { Cathedral } \\
\text { (SIPs } 10 \text { in.) }\end{array}$ & $\begin{array}{c}\text { R-50 } \\
\text { Cathedral } \\
\text { (aged phenolic) } \\
24 \text { in. O.C. } \\
\end{array}$ \\
\hline Cladding & Hardie ${ }^{\circledR}$ board and stack stone & Hardie ${ }^{\circledR}$ board and stack stone \\
\hline Exterior paint & CoolWall@ & CoolWall $\circledast$ \\
\hline Wall & $\begin{array}{c}\text { R-21 } \\
\text { SIPs (6 in. thick) }\end{array}$ & $\begin{array}{c}\text { R-21 } \\
2 \times 6 \text { wood frame, } 24 \text { in. centers } \\
\text { with } 1 / 2 \text { in. OSB } \\
\end{array}$ \\
\hline Wall cavity & SIP (EPS) & $\begin{array}{l}\text { Flash \& batt ( } 1 / 2 \text { in. foam with } R- \\
\qquad 16 \text { batt })\end{array}$ \\
\hline Window & $\begin{array}{c}\text { Pella triple pane, } \\
\text { third pane removable }\end{array}$ & $\begin{array}{c}\text { Pella triple pane, } \\
\text { third pane removable }\end{array}$ \\
\hline Floor & $\begin{array}{l}20 \text { in. truss between basement } \\
\text { \& first floor with installed } \\
\text { ductwork and } 18 \text { in. truss } \\
\text { between first and second floor. }\end{array}$ & $\begin{array}{l}20 \text { in. truss between basement } \\
\& \text { first floor with installed } \\
\text { ductwork. }\end{array}$ \\
\hline $\begin{array}{r}\text { Foundation } \\
\end{array}$ & Basement & Basement \\
\hline Weather-resistive barrier & DrainWrap $^{\mathrm{TM}}$ & Barritech VP Liquid applied \\
\hline Foundation wall above grade & $\begin{array}{l}12 \text { in. poured concrete with } \\
\text { exterior } 23 / 8 \text { in. fiberglass } \\
\text { drainage board insulation; } \\
\text { stone facade }\end{array}$ & $\begin{array}{l}10 \text { in. poured concrete with } \\
\text { exterior } 23 / 8 \text { in. fiberglass } \\
\text { drainage board insulation; } \\
\text { stone facade }\end{array}$ \\
\hline Foundation wall below grade & $\begin{array}{c}12 \text { in. poured concrete with } \\
\text { exterior } 23 / 8 \text { in. fiberglass } \\
\text { drainage board }\end{array}$ & $\begin{array}{l}10 \text { in. poured concrete with } \\
\text { exterior } 23 / 8 \text { in. fiberglass } \\
\text { drainage board }\end{array}$ \\
\hline
\end{tabular}

The means of using the process control capabilities of the data acquisition systems to simulate occupancy is described in detail elsewhere (Boudreaux and Gehl 2011). The research team used the Building America Research Benchmark (Hendron 2008) as the definition of national average occupancy. Loading of the washer and dryer is based on the Code of Federal Regulations (2010a), and refrigerator loading is based on the Code of Federal Regulations (2010b). Sensible heat gain from occupancy is simulated with infrared space heaters on the main level and upstairs. Lighting and major appliances are turned on and off per the national average benchmark schedules. The cycling of the clothes washer and dishwasher causes related hot water draws. The showers in the homes' master bedrooms are used to simulate the remaining domestic hot water usage (showers, baths, and sinks) and latent heat gain.

Houses 1 and 2 were rated in accordance with the Home Energy Rating System (HERS) methodology, and HERS ratings were determined using the Residential Energy Analysis and Rating Software. As part of the methodology, blower door tests were conducted to document the air tightness of the homes. For comparison, a nearby conventional stick-built house that was constructed in accordance with the 2006 International Energy Conservation Code (IECC) was also rated. Table 2.2 summarizes results of blower 
door tests and HERS ratings for House 1 and House 2 compared to the stick-built "builder house" that complies with IECC 2006.

Table 2.2. Comparison of HERS ratings and infiltration rates of House 1 (SIP house), House 2 (OVF house), and "Builder House"

\begin{tabular}{l|ccc}
\hline & House 1 & House 2 & Builder House $^{a}$ \\
\hline $\mathrm{ACH} @ 50 \mathrm{~Pa}^{b}$ & 1.23 & 1.74 & 5.7 \\
$\mathrm{HERS}^{c}$ & 46 & 47 & 101 \\
\hline
\end{tabular}

${ }^{a}$ Built to comply with IECC 2006 .

${ }^{b}$ Air changes per hour $(\mathrm{ACH})$ measured by blower door tests conducted at pressurization of $50 \mathrm{~Pa}$.

${ }^{c}$ Home Energy Rating System (HERS) - lower numbers indicate greater energy efficiency.

Houses 1 and 2 are intentionally very air tight and require mechanical ventilation to satisfy ASHRAE Standard 62.2. To satisfy this requirement, each house is outfitted with an energy recovery ventilator (ERV), whose operation and performance characteristics are described in detail elsewhere (Fantech 2010).

The space cooling and heating design loads for houses 1 and 2 were calculated using "Manual J: Residential Load Calculation" and associated software tools developed by the Air Conditioning Contractors of America (ACCA). The space conditioning design load calculations included consideration of the impact of ERV mechanical ventilation. The calculated design heating and total (sensible plus latent) cooling loads were $32,698 \mathrm{kBtu} / \mathrm{h}$ and $23,954 \mathrm{kBtu} / \mathrm{h}$ respectively for House 1, and 34,037 kBtu/h and $23,813 \mathrm{kBtu} / \mathrm{h}$ for House 2.

Space conditioning in houses 1 and 2 is provided by water-to-air heat pumps (WAHPs) connected to ground heat exchangers (combination of FHX and conventional HGHX, as described later). The WAHPs were sized using ACCA's "Manual S: Residential Equipment Selection" methodology as it applies to WAHPs. Nominal 2 ton capacity units with two-stage compressors were selected for both House 1 and House 2. For comparison, typically in East Tennessee, a house built to code and having $3,700 \mathrm{ft}^{2}$ of floor space would require a 4 to 5 ton nominal capacity unit for space conditioning (Im, Liu, and Monk 2011). Supplemental electric resistance heat was also installed.

It should be noted that both houses have multi-zone forced air distribution systems. Separate zone thermostats are provided for the master bedroom, the rest of the main floor living area, the upstairs, and the basement, for a total of four zones. The fact that the distribution systems are multi-zone on the air side does not influence space conditioning design loads or WAHP equipment selection, since the Manual J and Manual S methodologies are based on the whole-building block loads.

As noted previously, houses 1 and 2 are unoccupied research houses where the hot water usage is simulated to match the national average (54 gallons per day for these houses) as defined by the Building America Benchmark. The hot water systems in houses 1 and 2 are identical and comprised of a storage tank whose set temperature is maintained by a water-to-water heat pump (WWHP) connected to the same combination of FHX and HGHX used for space conditioning. The WWHPs selected were $1 \frac{1}{2}$ ton nominal capacity with integral recirculation pumps for both the source and load sides. On the source side the WWHPs are equipped with a control valve to limit the maximum leaving fluid temperature to $65^{\circ} \mathrm{F}$. 
Figure 2.3 is a photo of the WAHP and WWHP with associated hot water storage tank as installed in House 1. The equipment installation in House 2 is identical. The characteristics of the WAHP and WWHP units are summarized in Table 2.3.

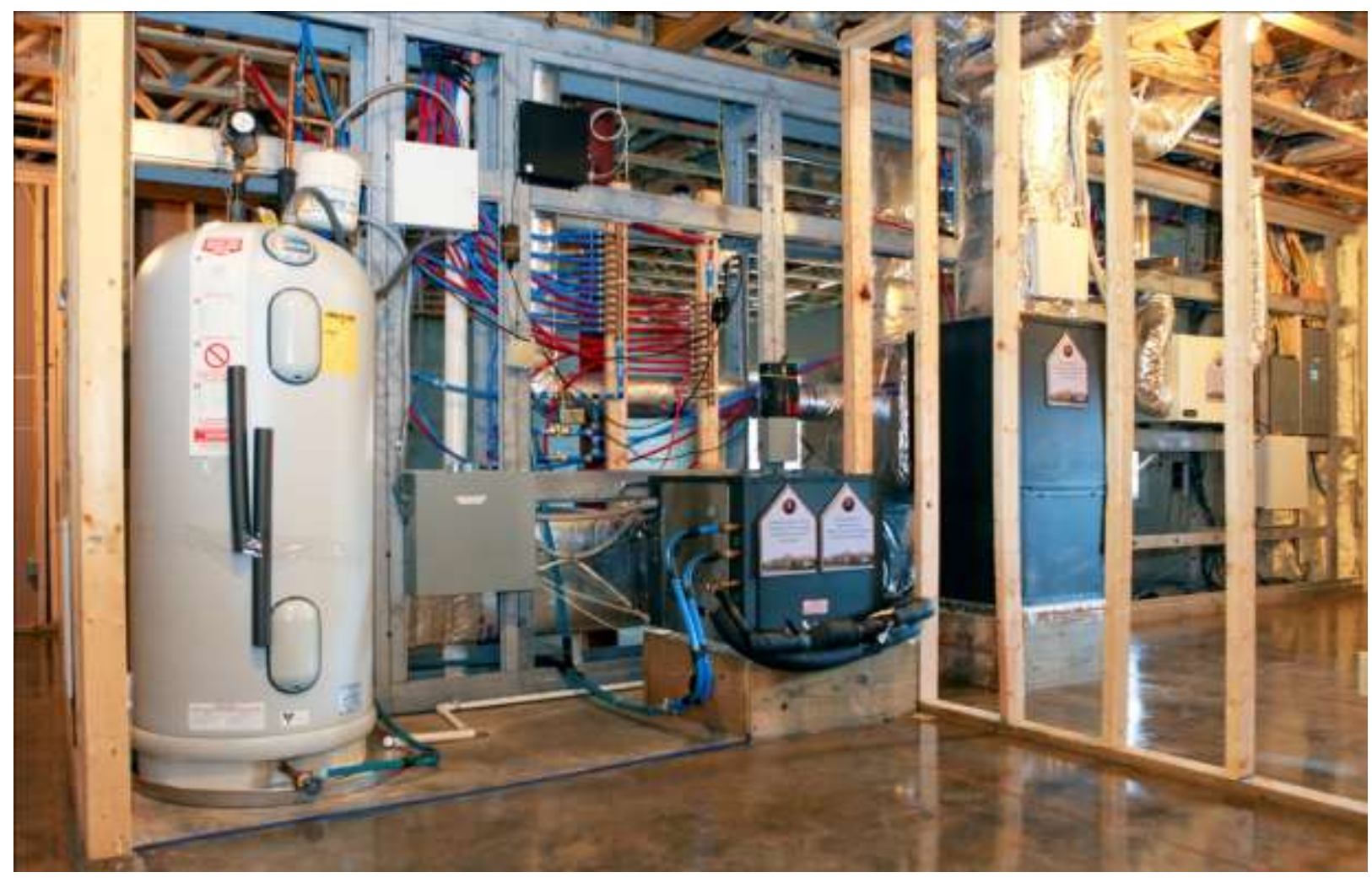

Figure 2.3. Space conditioning equipment (WAHP on right) and water heating equipment (WWHP and associated tank on left) at House 1.

\subsection{Description of Ground Heat Exchangers Installed in Houses 1 and 2}

In general, ground heat exchangers may be installed in the overcut around the basement walls, below the basement floor, in utility trenches (for buried water, sewer, and power lines), and in trenches for draining the footers. Depending on the application, the contractor may include extra trench in the design for installation of conventional horizontal ground heat exchangers (HGHX). This research project focused on the greatest technical challenge, which was developing and validating models and design tools for FHX inserted into the overcut around basement walls. In terms of performance modeling and design, ground heat exchangers in utility and footer drain trenches are no different from HGHX in supplemental trenches, and models and design tools for HGHX already exist. This project did not explicitly address models and design tools for ground heat exchangers installed below the basement floor, because that configuration has very simple geometry and boundary conditions, and we felt that this capability could be developed and added to the models and design tools later. We use the term FHX to refer exclusively to ground heat exchanger in the overcut around basement walls, and the term HGHX to refer to ground heat exchanger in utility, footer drain, or supplemental trenches. 
Table 2.3. Characteristics of WAHP and WWHP systems installed in House 1 and House 2

\begin{tabular}{|c|c|c|}
\hline & WAHP & WWHP \\
\hline \multicolumn{3}{|c|}{ Performance Metrics } \\
\hline $\mathrm{EFT}^{a}$ Range & $20-120^{\circ} \mathrm{F}$ & $20-110^{\circ} \mathrm{F}$ \\
\hline Capacity & 2 ton (nominal) & 1.5 ton (nominal) \\
\hline COP & $\begin{array}{l}\text { Cooling }^{b} \\
5.4 \text { (full load) at sink EFT }=77^{\circ} \mathrm{F} \\
7.6 \text { (part load) at sink EFT }=68^{\circ} \mathrm{F} \\
\text { Heating } \\
4.0 \text { (full load) at source EFT }=32^{\circ} \mathrm{F} \\
4.6 \text { (part load) at source EFT }=41^{\circ} \mathrm{F}\end{array}$ & $\begin{array}{l}\text { Heating at source EFT }=68^{\circ} \mathrm{F} \text { : } \\
5.2 \text { for } 90^{\circ} \mathrm{F} \text { load EFT } \\
3.7 \text { for } 120^{\circ} \mathrm{F} \text { load EFT } \\
\text { Heating at source EFT }=32^{\circ} \mathrm{F} \text { : } \\
3.5 \text { for } 90^{\circ} \mathrm{F} \text { load EFT } \\
2.5 \text { for } 120^{\circ} \mathrm{F} \text { load EFT } \\
\end{array}$ \\
\hline Airflow & $\begin{array}{l}\text { Cooling: } \\
850 \text { CFM rated (full load) } \\
725 \text { CFM rated (part load) } \\
\text { Heating: } \\
950 \text { CFM rated (full load) } \\
825 \text { CFM rated (part load) }\end{array}$ & NA \\
\hline $\begin{array}{l}\text { Fluid flow rate - ground } \\
\text { heat exchanger side }\end{array}$ & $1.5 \mathrm{gpm} / \mathrm{ton}$ & $\begin{array}{l}5.0 \mathrm{gpm} \text { (maximum) } \\
\text { Modulating valve maintains } \\
\mathrm{LFT}^{d} \text { below } 65^{\circ} \mathrm{F}\end{array}$ \\
\hline HW flow rate & NA & $3.5 \mathrm{gpm}$ \\
\hline \multicolumn{3}{|c|}{ Other Salient Features } \\
\hline Size, in. $(W \times H \times D)$ & $22.4 \times 48.5 \times 25.6$ & $24 \times 23.5 \times 24.5$ \\
\hline Weight & $266 \mathrm{lb}$ & $166 \mathrm{lb}$ \\
\hline Air coils & $\begin{array}{l}\text { Electro-coated to protect against } \\
\text { corrosion, airborne dust buildup, etc. }\end{array}$ & NA \\
\hline Compressor & $\begin{array}{l}\text { Copeland Scroll UltraTech }{ }^{\mathrm{TM}} \\
\text { Two-stage: } 67 \% \text { part-load capacity step }\end{array}$ & $\begin{array}{l}\text { LG }{ }^{\mathrm{TM}} \text { high-efficiency rotary } \\
\text { single stage }\end{array}$ \\
\hline Blower & Wheel $($ Dia $\times$ W $): 9 \times 7$ in & NA \\
\hline Blower motor & $\begin{array}{l}\text { Variable speed GE ECM } \\
\text { Half speed }(1 / 2 \mathrm{hp})[373 \mathrm{~W}] \\
\text { Full speed }(1 \mathrm{hp})[746 \mathrm{~W}]\end{array}$ & NA \\
\hline $\begin{array}{l}\text { Current RLA } \\
\text { Compressor } \\
\text { Blower motor } \\
\text { Pump } \\
\end{array}$ & $\begin{array}{r}\text { 10.3 Amps } \\
\text { 4.3 Amps } \\
0.8 \text { Amps } \\
\end{array}$ & $\begin{array}{l}\text { 6.6 Amps } \\
0.43 \text { Amps }\end{array}$ \\
\hline Ground loop fluid & $\begin{array}{l}20 \% \text { propylene glycol (by weight) in } \\
\text { water }\end{array}$ & $\begin{array}{l}20 \% \text { propylene glycol (by weight) in } \\
\text { water }\end{array}$ \\
\hline Refrigerant & $\begin{array}{l}\text { HFC- } 410 A \\
58 \text { oz. charge }\end{array}$ & $\begin{array}{l}\text { HFC- } 410 A \\
56 \text { oz. charge }\end{array}$ \\
\hline $\begin{array}{l}{ }^{a} \text { EFT = entering fluid tem } \\
{ }^{b} \text { Cooling coefficient of } p e \\
{ }^{c} \text { Heating coefficient of } p e \\
{ }^{d} \text { LFT = leaving fluid temp }\end{array}$ & $\begin{array}{l}\text { erature (entering heat pump from ground } \\
\text { ormance }(\mathrm{COP}) \text { at } 80.6^{\circ} \mathrm{F}\left(27^{\circ} \mathrm{C}\right) \mathrm{DB}, 66 \text {. } \\
\text { ormance }(\mathrm{COP}) \text { at } 68^{\circ} \mathrm{F}\left(20^{\circ} \mathrm{C}\right) \mathrm{DB}, 59^{\circ}( \\
\text { ature (entering ground heat exchanger fr }\end{array}$ & $\begin{array}{l}\text { at exchanger). } \\
\left(19^{\circ} \mathrm{C}\right) \text { WB entering air temperature. } \\
\text { C) WB entering air temperature. } \\
\text { heat pump). }\end{array}$ \\
\hline
\end{tabular}

The primary objective of the experiment, then, was to generate experimental data for FHX inserted into the overcut around basement walls, so that energy performance models and design tools for FHX in this configuration can be validated against the measured data. Further, it is desirable that the models and design tools have the flexibility to address applications where the ground heat exchanger may be comprised of a combination of FHX and HGHX. Hence, having a hybrid FHX/HGHX experimental system was an advantage. 
It is apparent from Figure 2.2 that the basement walls at the back of houses 1 and 2 are above grade and not available for FHX, and that each house has a basement wall with marginal usefulness for FHX because of a sloped grade. Hence the FHX was installed only along the two basement walls bounded by a full-depth and level grade - the north (street side) and west walls. The rest of the ground heat exchanger is HGHX installed in utility and supplemental trenches.

As no FHX design tool was available at the time, the team used a design tool for sizing conventional HGHX loops as a guide, and then applied engineering judgment. The team selected a six-pipe configuration, meaning six $3 / 4$ inch diameter high-density polyethylene pipes in the excavations (three fluid circuits - out and back) with a minimum spacing of $1 \mathrm{ft}$ between pipes. The soil thermal conductivity assumed was $0.75 \mathrm{Btu} /\left(\mathrm{hr} \cdot \mathrm{ft} \cdot{ }^{\circ} \mathrm{F}\right)$. Maximum and minimum heat pump entering fluid temperatures (EFTs) of $95^{\circ} \mathrm{F}$ and $30^{\circ} \mathrm{F}$ were used as the design constraints for sizing the ground heat exchanger. The necessary design values for heat extraction from the ground during winter and heat rejection to the ground during summer were derived from the space conditioning and water heating loads, and efficiency of equipment satisfying those loads, using a bin analysis.

It was estimated that 300 feet of excavation would be required for House 1 . The north and west basement walls are $46 \mathrm{ft}$ and $34 \mathrm{ft}$ long, respectively, for a total of $80 \mathrm{ft}$. Since the pipe follows the outside perimeter of the overcut excavation, which is longer than the actual basement wall due to features such as the fireplace and the outside corner between the north and west basement walls, the effective FHX excavation length is approximately $100 \mathrm{ft}$ (as determined by the 3D CAD model described in Section 2.4). The remaining $200 \mathrm{ft}$ of required excavation was provided in the form of utility or supplemental trenches.

The layout of the ground heat exchanger at House 1 (the SIP House) is illustrated in Figure 2.4. The trench for the buried electrical service entrance (northeast or upper right) provides $30 \mathrm{ft}$ of the $200 \mathrm{ft}$ required. The trench for the supply water connection (Southwest or lower left) provided $50 \mathrm{ft}$ of the $200 \mathrm{ft}$ required. The remaining required HGHX is installed south of the house. Although part of this HGHX segment is labeled "rain garden," the data show that a "rain garden" performs the same as the equivalent amount of six-pipe horizontal trench (i.e., the trench length required to accommodate the same amount of pipe as was installed in the rain garden). The equivalent length of six-pipe trench (in the rain garden or not) south of the house provides the remaining $120 \mathrm{ft}$ of the $200 \mathrm{ft}$ required. In other words, $60 \%$ (180 of $300 \mathrm{ft}$ ) of the excavations used for installation of the ground heat exchanger were required anyway to construct the home. 


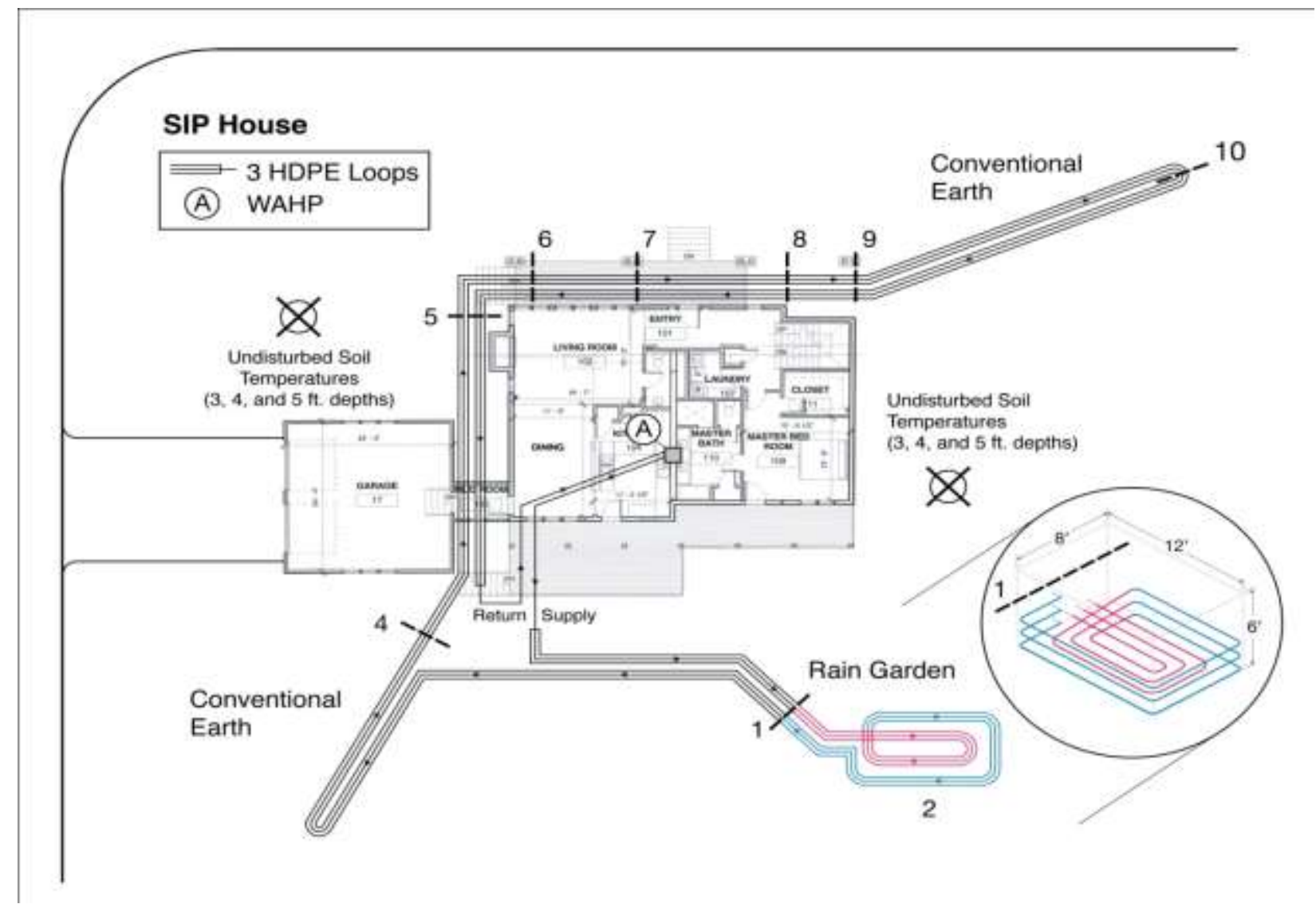

Figure 2.4. Layout of the FHX and HGHX at House 1.

It was estimated that 360 feet of excavation would be required for House 2. Again, the effective FHX excavation length is approximately $100 \mathrm{ft}$, so in this case an additional $260 \mathrm{ft}$ is required. The layout of the ground heat exchanger at House 2 (the OVF House) is illustrated in Figure 2.5. The trench for the buried electrical service entrance (northwest or upper left) provided $50 \mathrm{ft}$; the trench for the supply water connection (northeast or upper right) provided $30 \mathrm{ft}$; and the equivalent six-pipe trench (in the rain garden or not) south of the house provides the remaining $180 \mathrm{ft}$ of the $260 \mathrm{ft}$ required. In other words, 50\% (180 of $360 \mathrm{ft}$ ) of the excavations used for installation of the ground heat exchanger were required anyway to construct the home. 


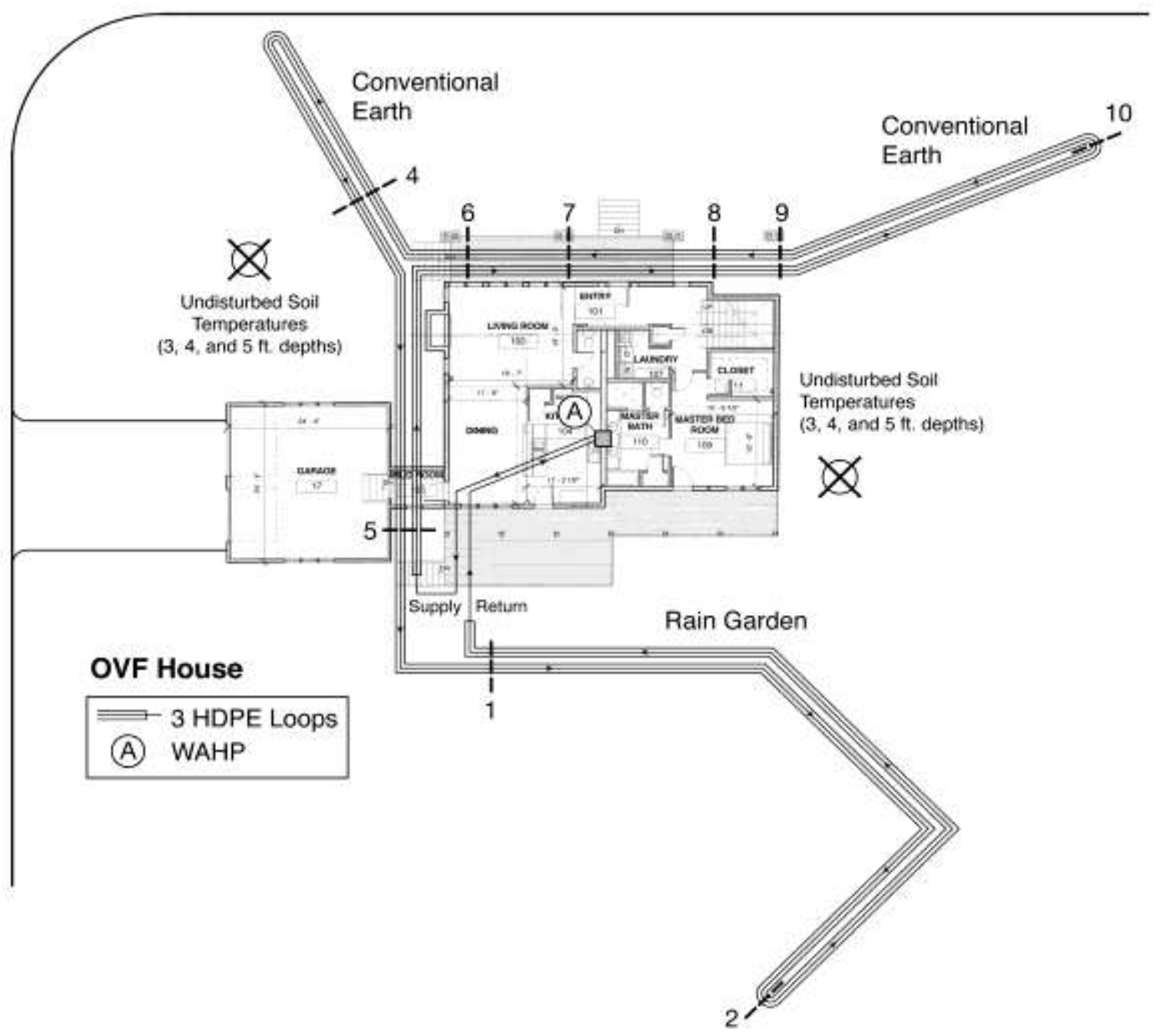

Figure 2.5. Layout of the FHX and HGHX at House 2.

As shown in Figure 2.6, the FHX/HGHX supply and return headers are brought into the basement by installing them under the basement floor and bringing them up through the floor near where the WAHP and WWHP units will be placed. The three parallel circuits comprising the FHX/HGHX tap off of the supply and return headers as shown in Figure 2.7. The flow direction of the fluid in the FHX/HGHX pipes is indicated in figures 2.4 and 2.5 for houses 1 and 2 .

Inside the basement, the WAHP and WWHP units are also installed in parallel with each other. Both heat pump units have internal pumps that activate to circulate FHX/HGHX fluid through their refrigerant-tofluid heat exchanger whenever compressors are cycled on. The FHX/HGHX working fluid is $20 \%$ by weight propylene glycol in water. Total fluid flow through the FHX/HGHX depends on whether neither, one, or both circulator pumps are operating.

Figures 2.8 and 2.9 shows a segment of FHX installed in the overcut around the basement wall, and HGHX installed in one of the utility trenches. 


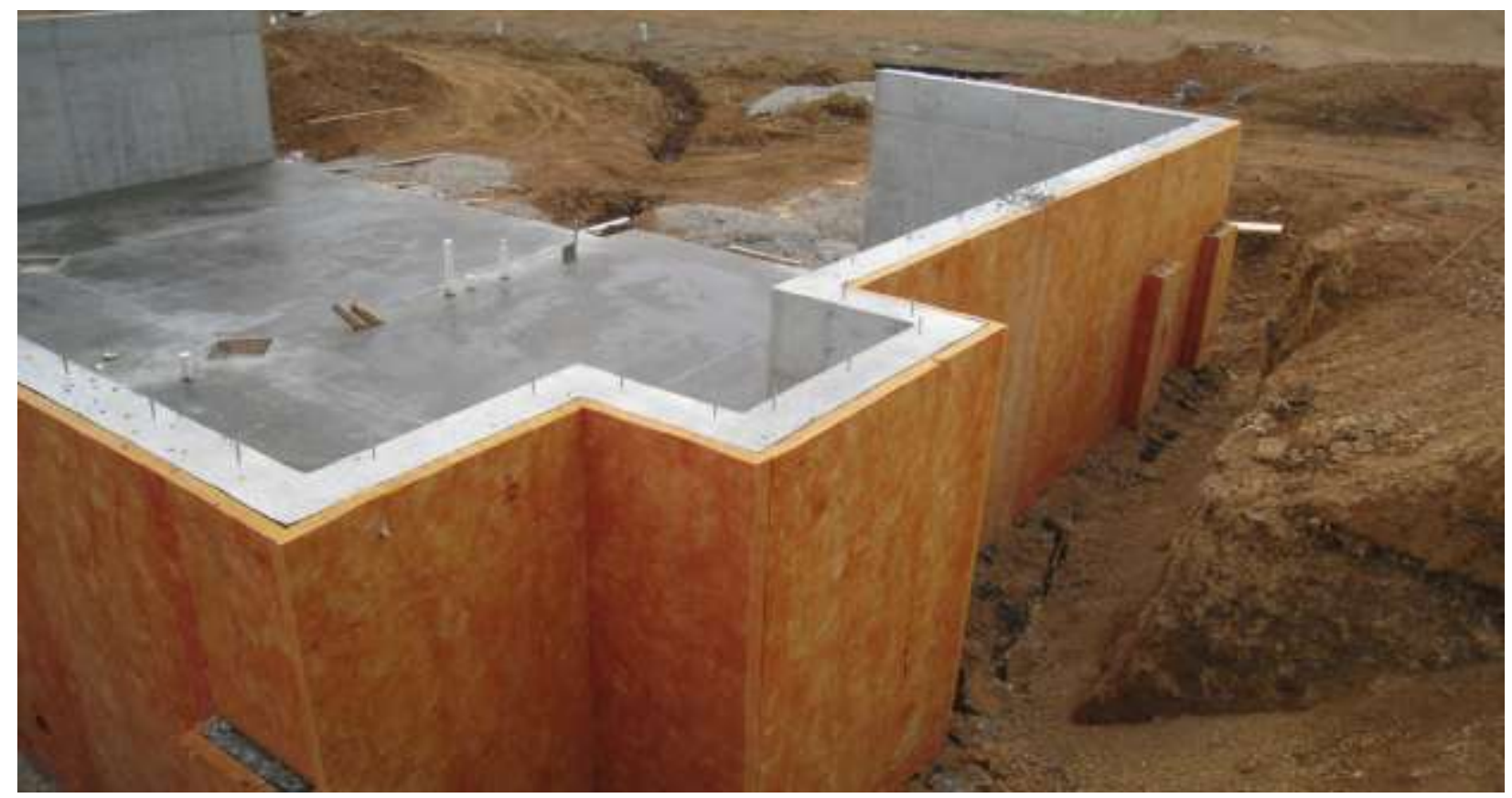

Figure 2.6. FHX/HGHX supply and return headers (brown covering) installed up through basement floor.

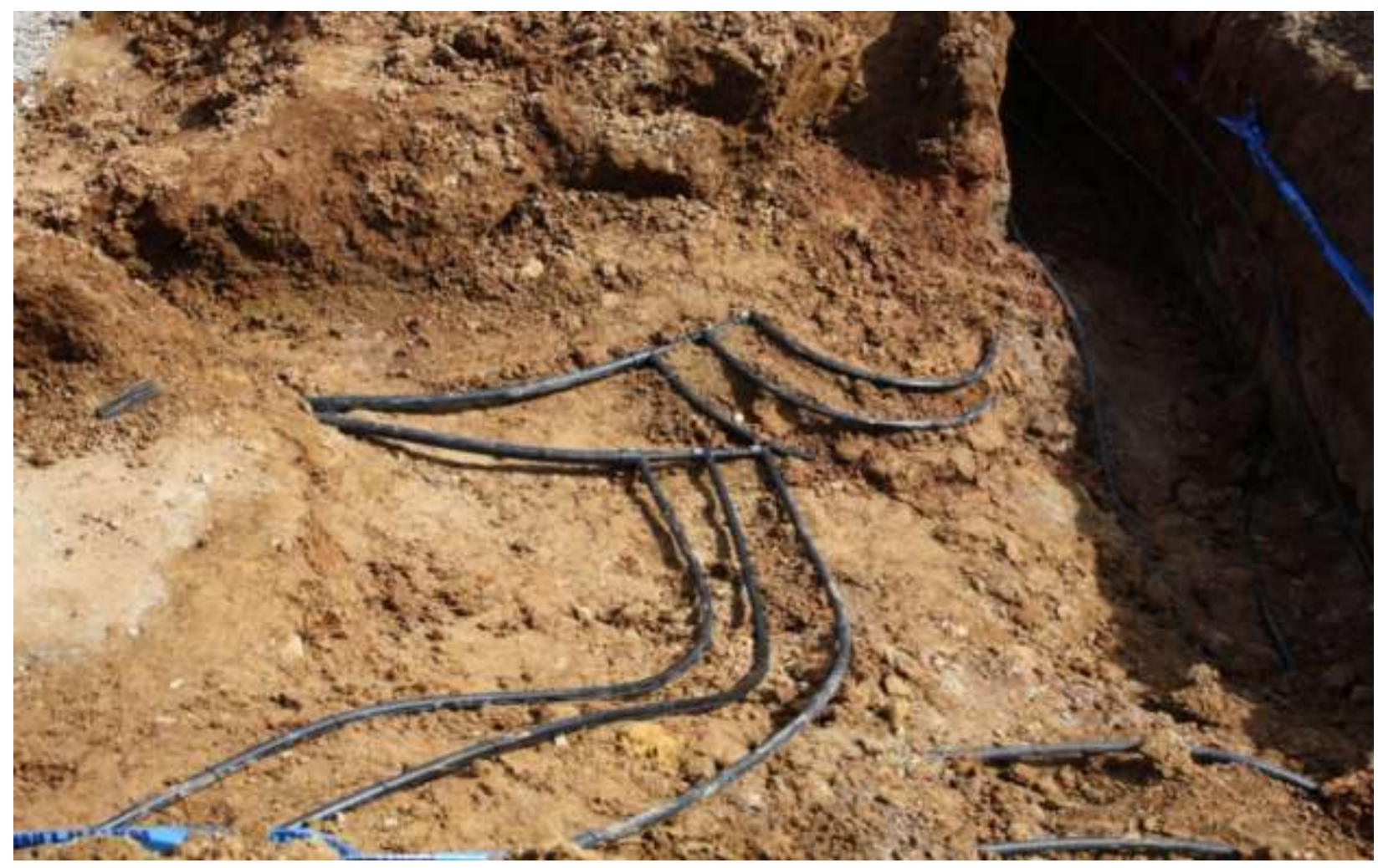

Figure 2.7. Connection of the three parallel FHX/HGHX circuits to the supply and return headers. 


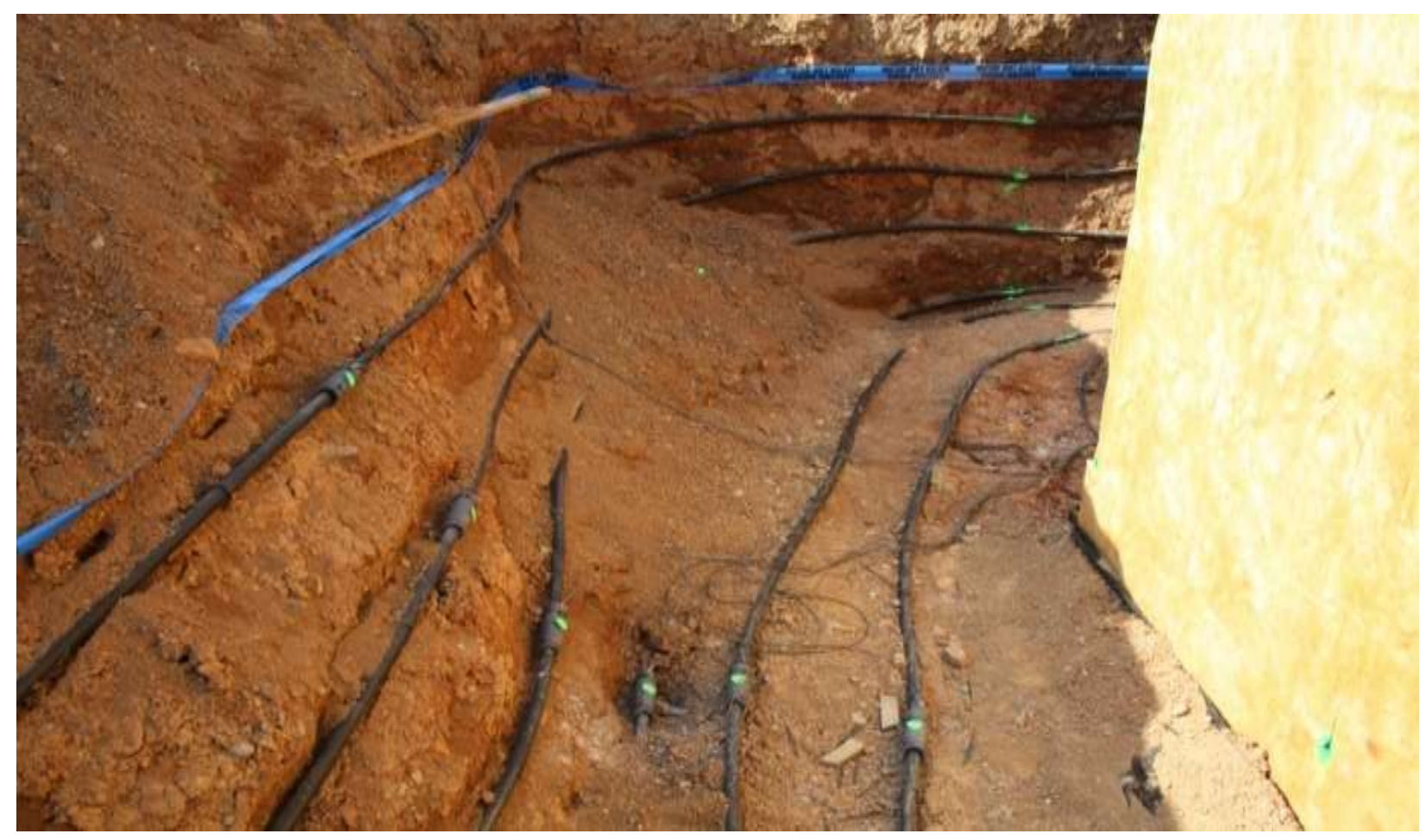

Figure 2.8. FHX installed in overcut around a basement wall exterior corner.

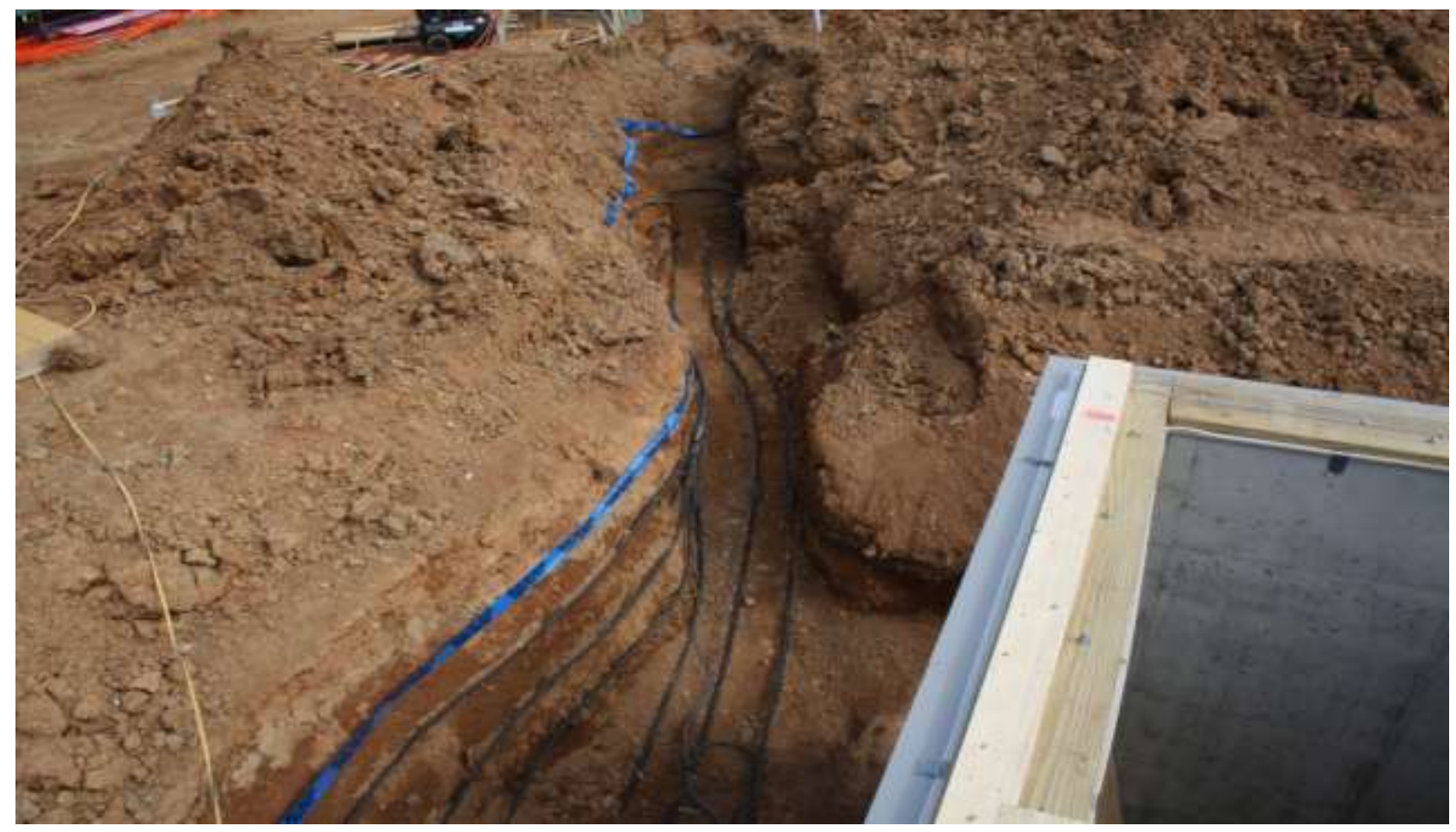

Figure 2.9. HGHX installed in a utility trench. 


\subsection{Ground Heat Exchanger Performance Measurements}

Measurements taken to establish FHX/HGHX performance and enable model validation included the thermal loads (heat rejection and extraction) imposed by the equipment, undisturbed far field temperature of the soil at various depths, numerous temperatures on the outside surface of the pipes, basement wall heat flux, drainage board and near-wall soil temperatures in a few locations, soil thermal conductivity, and weather data at the demonstration site.

The manufacturer of the WAHP and WWHP units installed a differential pressure transducer across the fluid side of the internal fluid-to-refrigerant heat exchanger and used factory turbine flow meter measurements to generate calibration curves for heat exchanger pressure drop vs. ground heat exchanger flow rate at several entering fluid temperature (EFT) values. These software-implemented calibration curves enabled fluid flow rate through the unit to be deduced from the pressure drop measurement during the field experiment. The valve modulating the fluid flow through the WWHP unit can result in very low flows under some operating conditions and insufficient measurement accuracy of the flow rate using the calibration curve approach. Therefore a redundant turbine flow meter measurement was included in the field experiment. Since the WAHP and WWHP were plumbed in parallel, the total FHX/HGHX fluid flow rate equaled the sum of the fluid flow rates through the separate units.

The manufacturer also installed thermal wells on the inlet and outlet of the fluid side of the internal fluidto-refrigerant heat exchanger. The thermal wells were used for fluid temperature measurements during the field experiment. Heat rejection to, or extraction from, the FHX/HGHX was deduced from the measurements of fluid flow rate and inlet and outlet fluid temperatures whenever the WAHP and WWHP compressors were operating. Appropriate corrections were applied during data reduction to account for the working fluid being $20 \%$ propylene glycol by weight in water, rather than pure water.

Undisturbed far field soil temperature measurements were taken at two different locations at 3 , 4 , and $5 \mathrm{ft}$ depths at houses 1 and 2. The locations of these measurements are shown in figures 2.4 and 2.5. The temperature measurements were made with thermistors that were carefully calibrated prior to installation.

Fluid temperatures along the FHX/HGHX pipes were approximated by measuring the outside pipe surface temperature of all six pipes at nine different locations, numbered as $1,2,4,5,6,7,8$, 9, and 10 (the number 3 was not used) in figures 2.4 and 2.5. Again, all temperature measurements were made with thermistors that were carefully calibrated prior to installation. The thermistors were applied directly to the outside of the pipes and then wrapped with insulation. Green dots were applied to the insulation over the thermistor locations to facilitate use of photogrammetric techniques (described later in this section) to document the exact sensor locations. For clarity on what was done, Figure 2.10 identifies for House 1 the nine pipe measurement locations and two undisturbed soil temperature measurement locations. The photo images in Figure 2.10 show how the sensor locations are marked with green dots.

At both houses, six heat flux transducers were installed to measure heat flux through the basement wall. Three of the wall heat flux transducers were located at pipe temperature location 6 , and the remaining three at pipe temperature location 7. Center lines of the transducers were approximately 1, 4, and $7 \mathrm{ft}$ below grade at both locations. Also at locations 6 and 7, temperatures were measured at the outside of the drainage board insulation at 1,4 , and $7 \mathrm{ft}$ below grade, and in the soil $2 \mathrm{ft}$ from the basement wall at 1 and $3 \mathrm{ft}$ below grade. Again, where feasible, the green dots and photogrammetric techniques were used to document the exact locations. 


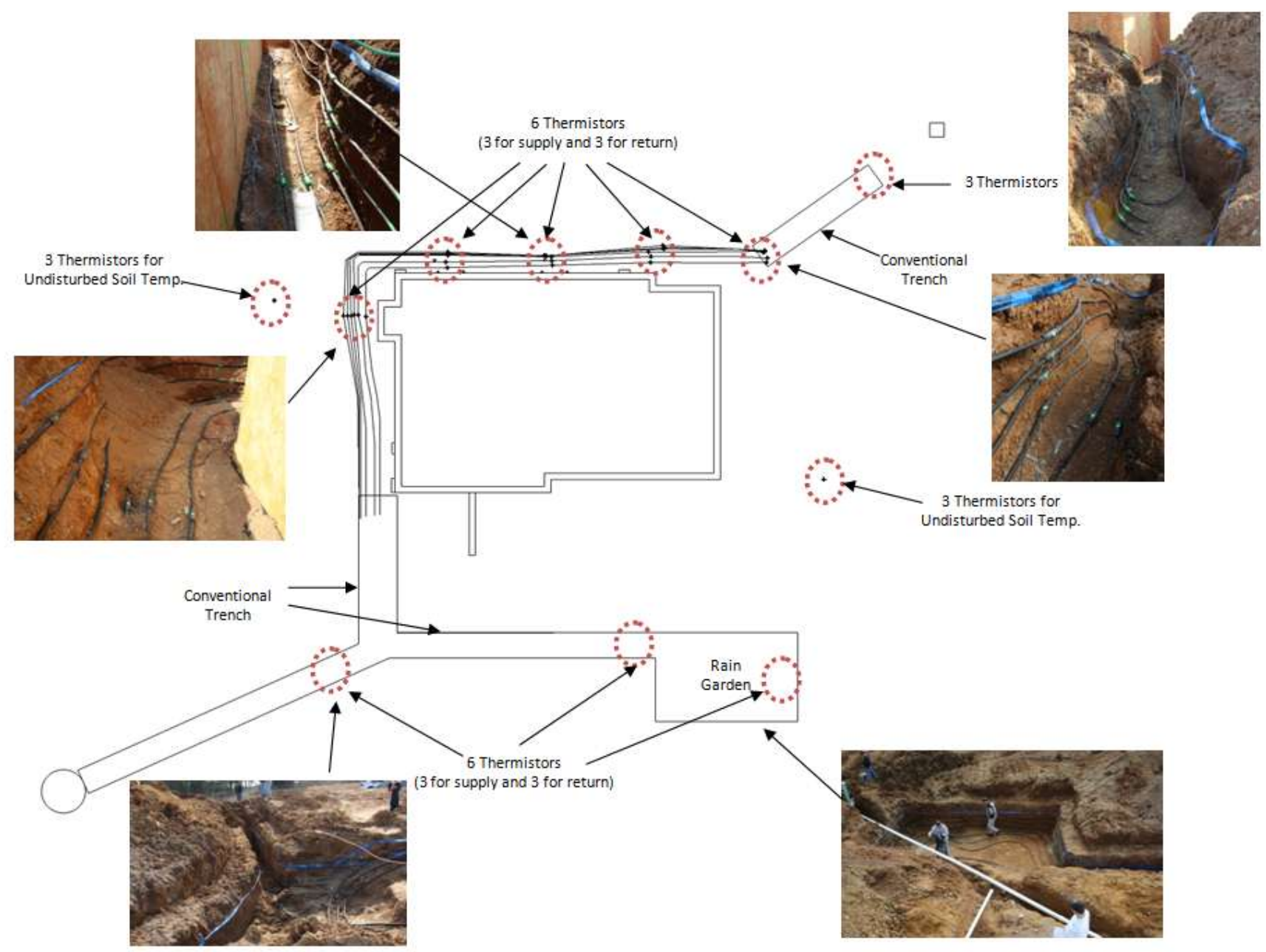

Figure 2.10. Location of pipe and undisturbed far field soil temperature sensors at House 1.

Prior to backfilling the foundations and trenches, a portable device known as the KD2 Pro, shown in Figure 2.11, was used to measure soil thermal conductivity at House 1. KD2 Pro measurements are based on the transient line heat source method. The manual measurements were taken at five locations as shown in Figure 2.12, corresponding to the north wall overcut, northeast utility trench, west wall overcut, southwest utility trench, and rain garden. At each location six measurements were taken, three at the bottom of the excavation and averaged, and the remaining three at the excavation side wall at 1,2, and 3 $\mathrm{ft}$ from the bottom and averaged. The results of these measurements are summarized in Table 2.4.

The in situ soil thermal conductivity measurements exhibited very large variation. It is unclear how much of the variation is attributable to actual changes in the thermal conductivity of soils only a few feet apart versus the measurement device itself. For the model and design tool validation studies described in Chapter 3, a soil thermal conductivity value of $0.68 \mathrm{Btu} /\left(\mathrm{hr} \cdot \mathrm{ft} \cdot{ }^{\circ} \mathrm{F}\right)$ was used, which corresponds to the simple arithmetic average of all the readings. As previously noted, a value of $0.75 \mathrm{Btu} /\left(\mathrm{hr} \cdot \mathrm{ft} \cdot{ }^{\circ} \mathrm{F}\right)$ was used in the calculations to size the FHX/HGHX for houses 1 and 2 . The handbook value range for heavy clay with $5 \%$ water is 0.6 to $0.8 \mathrm{Btu} /\left(\mathrm{hr} \cdot \mathrm{ft} \cdot{ }^{\circ} \mathrm{F}\right.$ ) (ASHRAE 2011). 


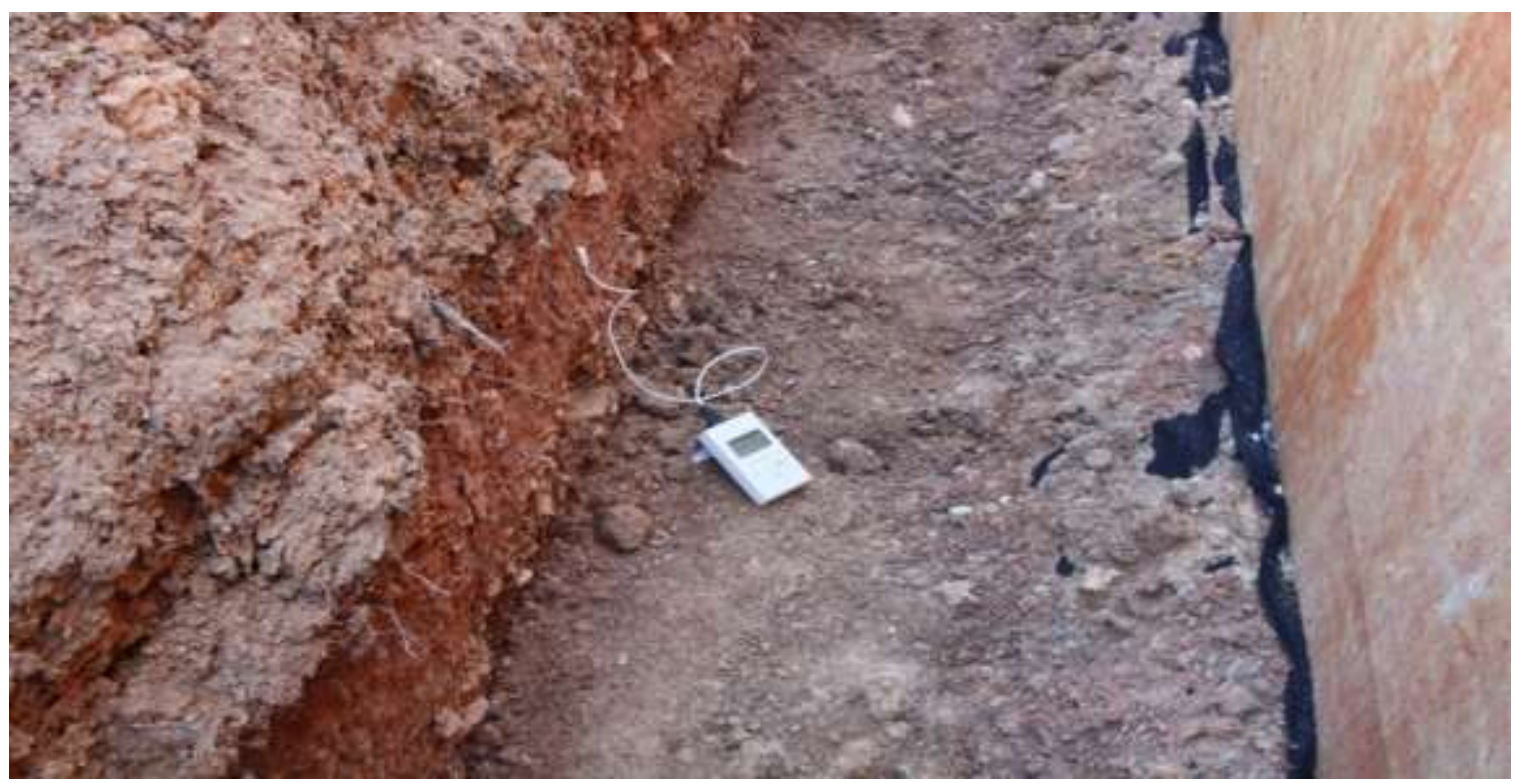

Figure 2.11. Portable soil thermal conductivity measurement device.

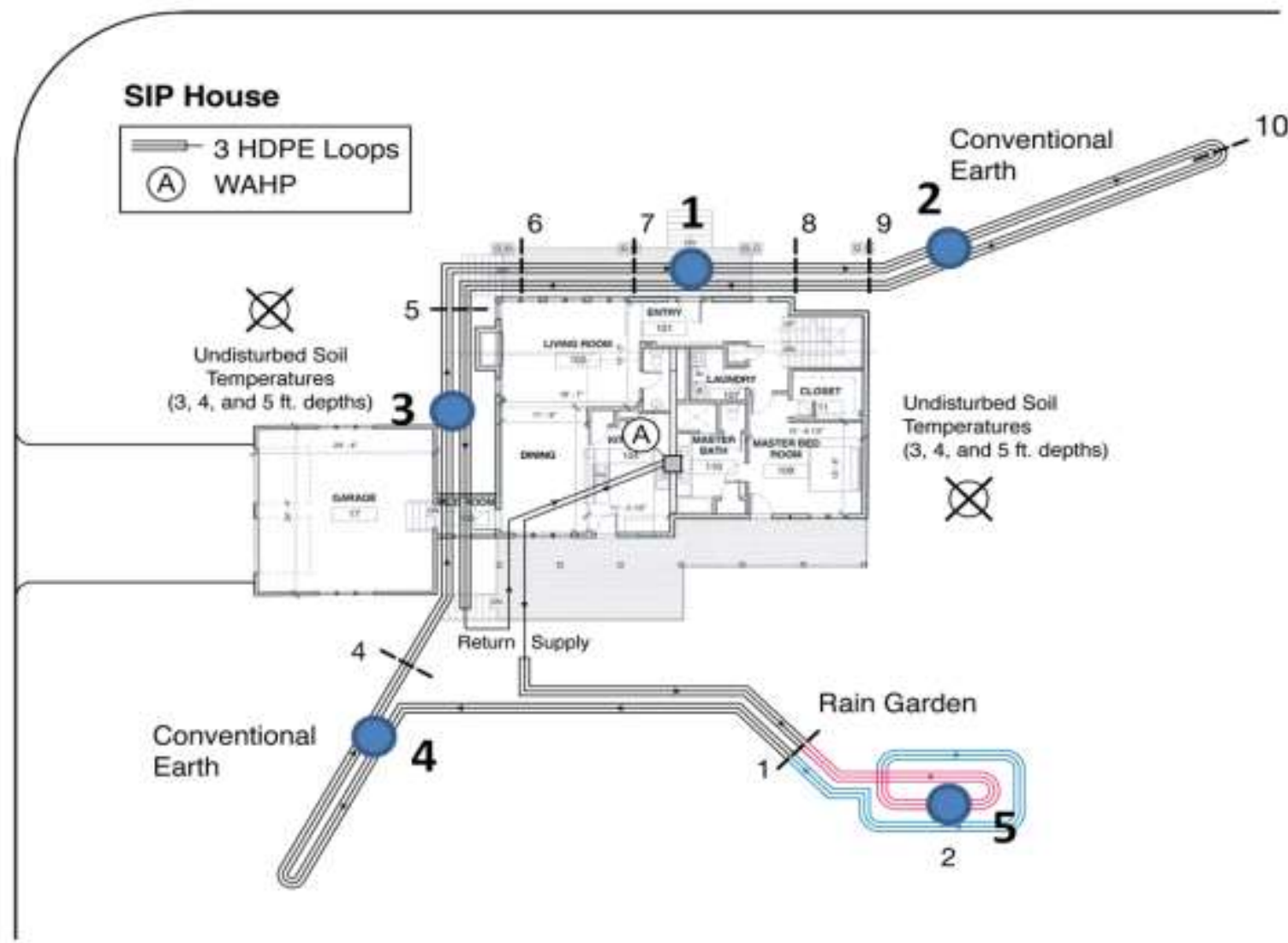

Figure 2.12. Manual soil thermal conductivity measurement locations (blue dots) at House 1. 
Table 2.4. Summary of in-situ soil thermal conductivity measurement results $\left(\mathbf{B t u} /\left(\mathbf{h r} \cdot \mathbf{f t}{ }^{\circ} \mathbf{F}\right)\right)$

\begin{tabular}{lccccc}
\hline & \multicolumn{5}{c}{ Location of Measurement } \\
\cline { 2 - 6 } Measured spot & $\mathbf{1}$ & $\mathbf{2}$ & $\mathbf{3}$ & $\mathbf{4}$ & $\mathbf{5}$ \\
& North wall & Utility trench & West wall & Utility trench & Rain garden \\
Bottom - average & 0.44 & 0.23 & 0.64 & 0.90 & 0.58 \\
Wall - average & 0.98 & 0.86 & 0.67 & 0.88 & 0.61 \\
\hline
\end{tabular}

In order to use the FHX/HGHX data to validate the models and design tool, it was critical to know the exact location of ground heat exchanger piping, temperature sensors, heat flux transducers, and other features in relation to the basement walls. Given the nature of construction sites, it was expected that the excavations would take irregular shapes, making it difficult to document the actual geometry of what was installed. In addition, the location of pipes and sensors cannot be determined after the excavations are backfilled. For this reason, photogrammetric techniques that allow the spatial location of objects to be determined from photographs were used to develop an accurate geometric model of the FHX/HGHX and foundations. PhotoModeler, a software tool which helps to create accurate, high-quality, threedimensional (3D) models and measurements from photographs using an ordinary camera, was used for this purpose. (More information on this general technique and the PhotoModeler tool are available at http://www.photomodeler.com.)

In the simplest example, the 3D coordinates of points on an object are determined from measurements made on two or more photographic images taken from different angles. When common points are identified on each image, a line of sight can be constructed from the camera location to the point on the object. The intersection of these rays then determines the 3D location of the point. For each important feature, certain key reference points and reference lengths were identified. For example, numbered stickers were affixed to the ground heat exchanger piping at three-foot intervals. Further, the previously mentioned green dots were affixed to each sensor location. Photographs of the foundations and the piping were then taken from multiple angles around the site. Based on the photographs, the software interpreted these key reference points and lengths and produced a 3D CAD model of the FHX/HGHX and foundations.

Figures 2.13 and 2.14 show the final 3D CAD models of houses 1 and 2, respectively. In these models, the six pipes (three for supply and three for return) and the sensors for the FHX in the overcuts around the basement walls were modeled individually, whereas the conventional HGHX is modeled as one line for each three pipes, whether supply or return.

Based on the 3D CAD models, one can easily determine the 2D coordinates locating features such as the basement wall, FHX pipes, and sensors on pipes for a specific cross section perpendicular to the pipe and basement wall. By manually outputting multiple 2D cross sections and averaging them, the 3D CAD model was used to determine the average coordinates of these features along the entire length of the north and west basement walls having FHX. This capability was extremely useful for model validation using the measured data. An example of a 2D cross section generated by the 3D model appears in Figure 2.15. 


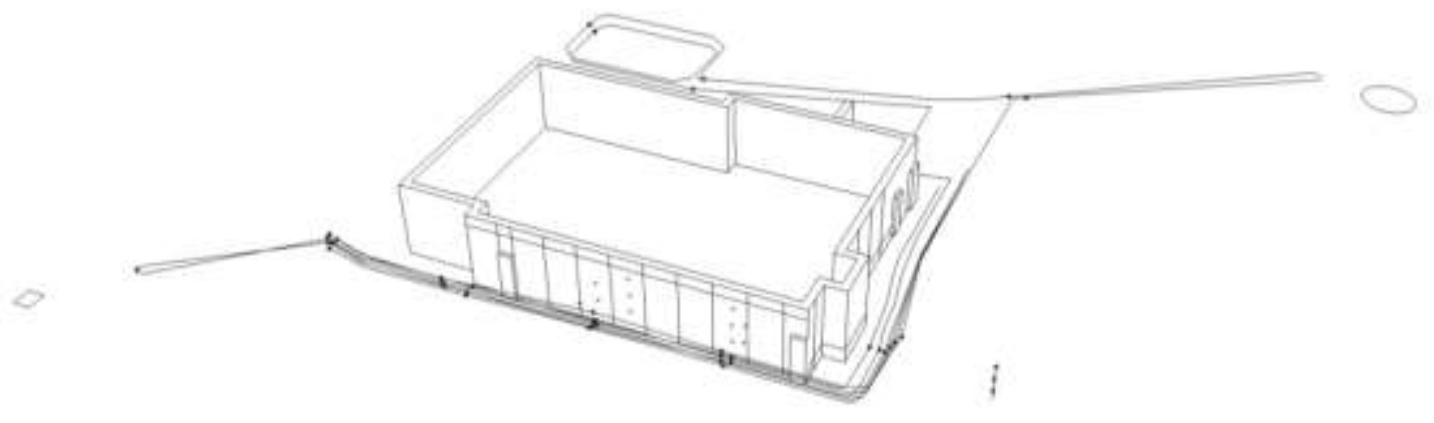

Figure 2.13. 3D model of the FHX/HGHX and foundation of House 1.

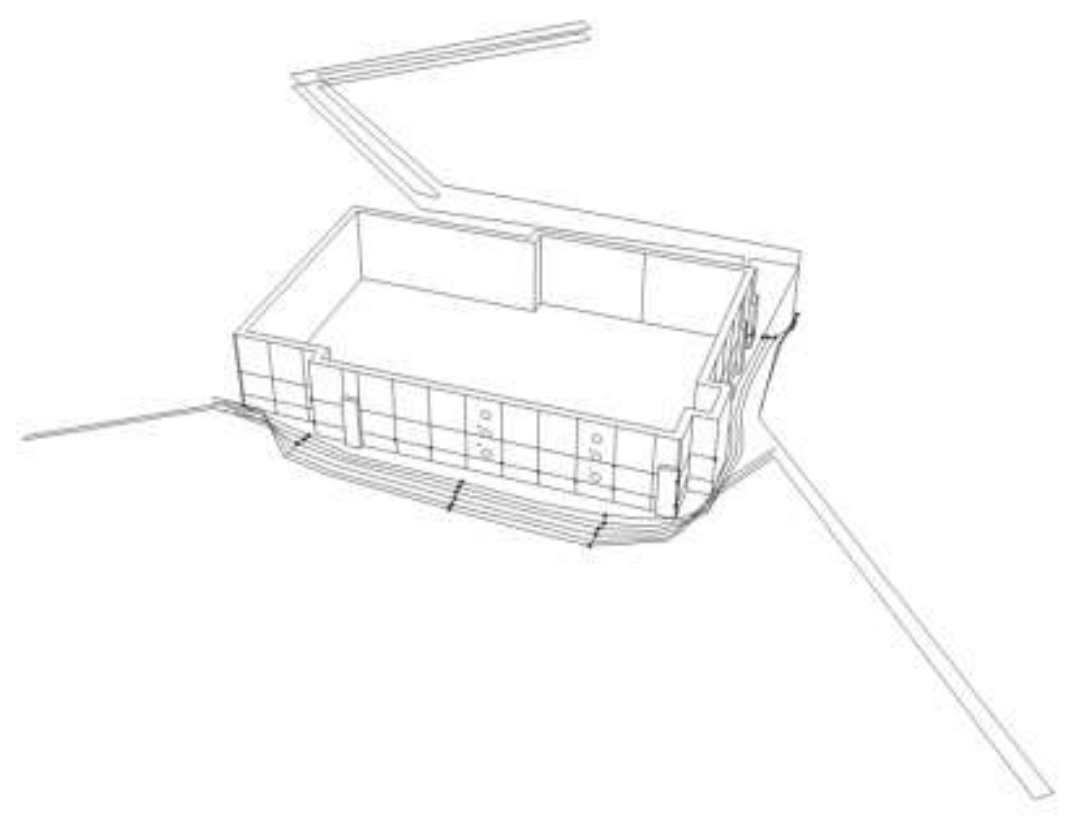

Figure 2.14. 3D model of the FHX/HGHX and foundation of House 2. 

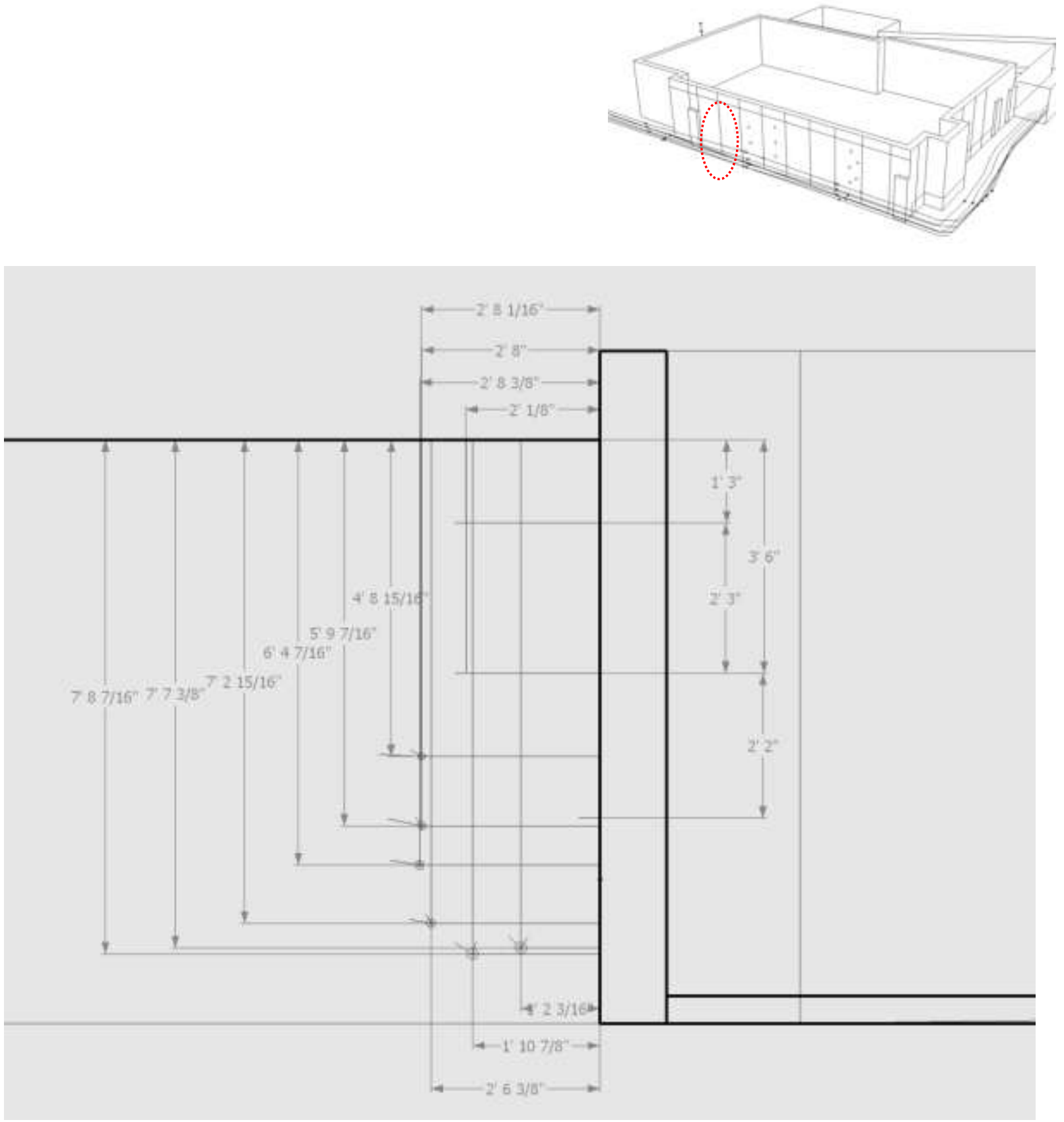

Figure 2.15. 2D cross section for the House 1 foundation location indicated in the 3D image on upper right.

For weather data, a collection station was mounted on the roof of House 1. The station measures outdoor dry bulb temperature, relative humidity, night-sky and solar irradiance, wind speed and direction, precipitation, and barometric pressure.

A comprehensive list of all measurements taken to establish FHX/HGHX performance and enable model and design tool validation is provided in the Appendix. The data was collected and stored using Campbell 
Scientific Model CR3000 micro-loggers and retrieved remotely over dedicated telephone lines. Frequent data retrieval enabled the project team to have early warning of data channel malfunctions so that any issues could be resolved quickly. In general the data is measured at a rapid scan rate with averages logged at 15 minute intervals, but some channels were logged at intervals as short as 1 minute as necessary.

\subsection{Measured Performance}

The WAHP and WWHP units were replaced by prototypes of a new ground-source integrated heat pump in December 2010, which interrupted data collection. Hence all of the measured performance reported here is for January through November 2010. However, eleven months was an ample data set for deriving accurate analytical approaches (e.g., empirical models) to estimate values for December 2010, enabling performance results to be reported for a full year.

Measured performance for the space conditioning systems at houses 1 and 2 is summarized in tables 2.5 and 2.6. In both houses the heating and cooling thermostat set points in all four zones were maintained throughout the year at 71 and $76^{\circ} \mathrm{F}$. It appears that the hybrid FHX/HGHX systems were reasonably well sized at both houses. Annual maximum and minimum EFTs measured at houses 1 and 2 were $93.2^{\circ} \mathrm{F}$ and $33.4^{\circ} \mathrm{F}$, and $90.3^{\circ} \mathrm{F}$ and $33.7^{\circ} \mathrm{F}$, respectively. These values compare well with the design values for maximum and minimum EFT of $95^{\circ} \mathrm{F}$ and $30^{\circ} \mathrm{F}$ used to size the FHX/HGHX. The measured WAHP heating and cooling COPs are also about what would be expected for a GSHP system with a properly sized ground heat exchanger. Data analysis beyond what is shown in the tables indicated that the supplemental electric resistance heating elements were never activated at House 1 and consumed only 66 $\mathrm{kWh}$ at House 2, which verifies that the WAHPs were appropriately sized at 2 tons nominal capacity.

Table 2.5. Summary of measured performance of space conditioning system at House $\mathbf{1}^{a}$

\begin{tabular}{|c|c|c|c|c|c|c|c|c|c|c|c|}
\hline \multirow[t]{2}{*}{ Month } & \multicolumn{2}{|c|}{ Electric consumption } & \multicolumn{2}{|c|}{$\begin{array}{c}\text { Energy delivered/removed } \\
\text { (loads met) }\end{array}$} & \multicolumn{2}{|c|}{$\begin{array}{c}\text { Coefficient of } \\
\text { Performance (COP) } \\
\text { (includes pumping) }\end{array}$} & \multicolumn{3}{|c|}{$\begin{array}{l}\text { "On" Entering Fluid Temp. } \\
\text { (EFT) }\end{array}$} & \multicolumn{2}{|c|}{$\begin{array}{l}\text { "On" Average } \\
\text { Outdoor Air } \\
\text { Temp. (OAT) }\end{array}$} \\
\hline & $\begin{array}{l}\text { Heating } \\
\text { (kWh) }\end{array}$ & $\begin{array}{l}\text { Cooling } \\
\text { (kWh) }\end{array}$ & $\begin{array}{l}\text { Heating } \\
\text { (kWh) }\end{array}$ & $\begin{array}{l}\text { Cooling } \\
\text { (KWh) }\end{array}$ & Heating & Cooling & $\begin{array}{l}\text { Min } \\
\left({ }^{\circ} \mathrm{F}\right)\end{array}$ & $\begin{array}{l}\text { Avg. } \\
\left({ }^{\circ} \mathrm{F}\right)\end{array}$ & $\begin{array}{l}\text { Max. } \\
\left({ }^{\circ} \mathrm{F}\right)\end{array}$ & $\begin{array}{l}\text { Heat } \\
\left({ }^{\circ} \mathrm{F}\right)\end{array}$ & $\begin{array}{l}\text { Cool } \\
\left({ }^{\circ} \mathrm{F}\right)\end{array}$ \\
\hline 10-Jan & 856.1 & 0 & 3051 & 0 & 3.6 & & 36.6 & 40.3 & 45.8 & 31.7 & \\
\hline 10-Feb & 823.9 & 0 & 2829.9 & 0 & 3.4 & & 33.4 & 37 & 40.9 & 33.3 & \\
\hline 10-Mar & 565.8 & 0 & 1987.1 & 0 & 3.5 & & 33.6 & 38.7 & 44.5 & 44.5 & \\
\hline 10-Apr & 61.8 & 36.3 & 252.9 & 218.3 & 4.1 & 6 & 41.9 & 51.2 & 58.4 & 51.9 & 76.3 \\
\hline $\begin{array}{l}\text { 10- } \\
\text { May }\end{array}$ & 0.5 & 158.7 & 2.2 & 857.1 & 4.6 & 5.4 & 55.2 & 63.8 & 70.1 & 53.8 & 75.9 \\
\hline 10-Jun & 0 & 387 & 0 & 1789.1 & & 4.6 & 65.6 & 75.8 & 84.8 & & 81.4 \\
\hline 10-Jul & 0 & 532.5 & 0 & 2182 & & 4.1 & 75.6 & 83.8 & 89.5 & & 82 \\
\hline 10-Sep & 0 & 384.3 & 0 & 1508 & & 3.9 & 78.8 & 86.2 & 93.2 & & 77.4 \\
\hline 10-Oct & 2.9 & 46.9 & 14.2 & 211.5 & 4.9 & 4.5 & 65.1 & 76.1 & 83.6 & 38.7 & 69.8 \\
\hline 10-Nov & 137.4 & 0 & 625.2 & 0 & 4.6 & & 55.2 & 60.9 & 67.8 & 39.5 & \\
\hline 10-Dec & 842.4 & 0 & 2973.3 & 0 & 3.5 & & - & 44.8 & - & 31.3 & \\
\hline Total & $3,290.8$ & $2,180.8$ & $11,735.8$ & $9,160.1$ & 3.6 & 4.2 & 33.4 & 59.8 & 93.2 & 35.4 & 80.1 \\
\hline
\end{tabular}

${ }^{a}$ December values are estimated. 
Table 2.6. Summary measured performance of space conditioning system at House $2^{a}$

\begin{tabular}{|c|c|c|c|c|c|c|c|c|c|c|c|}
\hline \multirow[t]{2}{*}{ Month } & \multicolumn{2}{|c|}{$\begin{array}{c}\text { Electric } \\
\text { Consumption }\end{array}$} & \multicolumn{2}{|c|}{$\begin{array}{c}\text { Energy Delivered/Removed } \\
\text { (Loads Met) }\end{array}$} & \multicolumn{2}{|c|}{$\begin{array}{c}\text { Coefficient of } \\
\text { Performance (COP) } \\
\text { (Includes Pumping) }\end{array}$} & \multicolumn{3}{|c|}{$\begin{array}{l}\text { “On" Entering Fluid Temp. } \\
\text { (EFT) }\end{array}$} & \multicolumn{2}{|c|}{$\begin{array}{l}\text { "On" Average } \\
\text { Outdoor Air } \\
\text { Temp. (OAT) }\end{array}$} \\
\hline & $\begin{array}{l}\text { Heating } \\
(\mathrm{kWh})\end{array}$ & $\begin{array}{l}\text { Cooling } \\
\text { (kWh) }\end{array}$ & $\begin{array}{l}\text { Heating } \\
(\mathrm{kWh})\end{array}$ & $\begin{array}{l}\text { Cooling } \\
\text { (kWh) }\end{array}$ & Heating & Cooling & $\begin{array}{l}\text { Min } \\
\left({ }^{\circ} \mathrm{F}\right)\end{array}$ & $\begin{array}{l}\text { Avg. } \\
\left({ }^{\circ} \mathrm{F}\right)\end{array}$ & $\begin{array}{l}\text { Max. } \\
\left({ }^{\circ} \mathrm{F}\right)\end{array}$ & $\begin{array}{l}\text { Heat } \\
\left({ }^{\circ} \mathrm{F}\right)\end{array}$ & $\begin{array}{l}\text { Cool } \\
\left({ }^{\circ} \mathrm{F}\right)\end{array}$ \\
\hline 10-Jan & 1084.4 & 0 & 3801.1 & 0 & 3.5 & & 36.8 & 39.8 & 47.3 & 32.1 & \\
\hline $10-F e b$ & 1028.6 & 0 & 3495.6 & 0 & 3.4 & & 33.7 & 36.2 & 39.4 & 33.9 & \\
\hline 10-Mar & 684.8 & 0 & 2399.4 & 0 & 3.5 & & 34.3 & 38.9 & 43.9 & 45.1 & \\
\hline 10-Apr & 126.9 & 37.6 & 531.3 & 235.8 & 4.2 & 6.3 & 42.5 & 51.3 & 56.3 & 55 & 77.3 \\
\hline 10-May & 7.3 & 157.1 & 33.4 & 841.8 & 4.6 & 5.4 & 54.8 & 63.3 & 68.9 & 55.5 & 77.6 \\
\hline 10-Jun & 0 & 442.5 & 0 & 1967.1 & & 4.4 & 66.2 & 75.1 & 80.8 & & 82.3 \\
\hline 10-Jul & 0 & 610.9 & 0 & 2403.7 & & 3.9 & 75.8 & 82.6 & 87.3 & & 82.3 \\
\hline 10-Aug & 0 & 667.1 & 0 & 2437.5 & & 3.7 & 81.9 & 87.2 & 90.3 & & 82.1 \\
\hline 10-Sep & 0 & 352.2 & 0 & 1353 & & 3.8 & 78.2 & 84 & 88.1 & & 78.6 \\
\hline 10-Oct & 8.3 & 17.9 & 41.1 & 79.5 & 5 & 4.4 & 66.8 & 73.6 & 79.9 & 39.4 & 73.3 \\
\hline 10-Nov & 210 & 0 & 956.4 & 0 & 4.6 & & 55.5 & 60.3 & 68.2 & 42.8 & \\
\hline 10-Dec & $1,056.7$ & 0 & $3,689.5$ & 0 & 3.5 & & - & 43.1 & - & 31.9 & \\
\hline Total & $4,207.0$ & $2,285.3$ & $14,947.8$ & $9,318.4$ & 3.6 & 4.1 & 33.7 & 55.0 & 90.3 & 36.4 & 81.5 \\
\hline
\end{tabular}

Measured performance of the water heating systems at houses 1 and 2 is summarized in tables 2.7 and 2.8. Although the water heating COPs observed at House 1 were as expected, the water heating COPs at House 2 were considerably lower. This is one of the reasons why the data set from House 1 was used to validate the FHX/HGHX models and design tool. The lower than expected water heating efficiency at House 2 was attributable to a smaller source-side pump than in House 1. As a result the WWHP experienced lower loop flow, especially when it had to compete with the larger pump in the WAHP when both were operating simultaneously.

A more detailed understanding of the performance of the space conditioning and water heating systems at Houses 1 and 2 is conveyed by tables 2.9 and 2.10, which summarize measured performance by standard $5^{\circ} \mathrm{F}$ outdoor air temperature bin, as is common practice in the ASHRAE community. Higher space conditioning loads were anticipated in House 2, and they materialized for heating but not for cooling. The slightly higher cooling at House 1 may be attributable to this house being a frequent tour stop for visitors to ORNL when the weather is nice. The higher estimated space conditioning loads for House 2 caused the project team to size the House $2 \mathrm{FHX} / \mathrm{HGHX}$ excavation at $360 \mathrm{ft}$ compared to $300 \mathrm{ft}$ at House 1, which explains the slightly lower heat pump EFTs during WAHP cooling and WWHP water heating operation. The average EFTs for "on" heating, cooling, and water heating are plotted by bin in figures 2.16 and 2.17. 
Table 2.7. Summary of measured performance of water heating system at House $\mathbf{1}^{a}$

\begin{tabular}{c|cccc}
\hline & $\begin{array}{c}\text { Electric } \\
\text { Consumption of } \\
\text { WWHP and Pumps } \\
(\mathrm{kWh})\end{array}$ & $\begin{array}{c}\text { Average WWHP } \\
\text { EFT When "On" } \\
(\mathrm{F})\end{array}$ & $\begin{array}{c}\text { Average COP } \\
\text { (ncludes Pumping) }\end{array}$ & $\begin{array}{c}\text { Water Heating } \\
\text { Energy Delivered } \\
\text { (kBtu) }\end{array}$ \\
\hline 10-Jan & 149 & 40.3 & 2.8 & 1,418 \\
10-Feb & 129 & 37.3 & 2.7 & 1,190 \\
10-Mar & 138 & 39.5 & 2.7 & 1,267 \\
10-Apr & 100 & 51.3 & 3.0 & 1,010 \\
10-May & 97 & 62.0 & 3.1 & 1,028 \\
10-Jun & 86 & 73.9 & 3.4 & 984 \\
10-Jul & 74 & 82.5 & 3.3 & 848 \\
10-Aug & 96 & 87.5 & 3.4 & 1,125 \\
10-Sep & 95 & 83.9 & 3.6 & 1,181 \\
10-Oct & 107 & 73.7 & 3.5 & 1,257 \\
10-Nov & 108 & 63.2 & 3.3 & 1,209 \\
10-Dec & 142 & 36.3 & 2.8 & 1,342 \\
Total & $\mathbf{1 3 2 1}$ & $\mathbf{5 7 . 0}$ & $\mathbf{3 . 1}$ & $\mathbf{1 3 , 8 5 8}$ \\
\hline T. & & & &
\end{tabular}

${ }^{\bar{a}}$ December values are estimated.

Table 2.8. Summary of measured performance of water heating system at House $2^{a}$

\begin{tabular}{|c|c|c|c|c|}
\hline & $\begin{array}{c}\text { Electric } \\
\text { Consumption of } \\
\text { WWHP and Pumps } \\
(\mathrm{kWh})\end{array}$ & $\begin{array}{l}\text { Average WWHP } \\
\text { EFT When "On" } \\
(\mathrm{F})\end{array}$ & $\begin{array}{c}\text { Average COP } \\
\text { (Includes Pumping) }\end{array}$ & $\begin{array}{l}\text { Water Heating } \\
\text { Energy Delivered } \\
(\mathrm{kBtu})\end{array}$ \\
\hline 10-Jan & 132 & 40.2 & 2.3 & 1,019 \\
\hline 10-Feb & 136 & 36.6 & 2.2 & 1,039 \\
\hline 10-Mar & 153 & 39.7 & 2.4 & 1,277 \\
\hline 10-Apr & 104 & 50.8 & 2.7 & 959 \\
\hline 10-May & 107 & 62.1 & 2.7 & 991 \\
\hline 10-Jun & 94 & 72.0 & 2.7 & 879 \\
\hline 10-Jul & 89 & 81.4 & 2.8 & 845 \\
\hline 10-Aug & 88 & 85.6 & 2.8 & 834 \\
\hline 10-Sep & 93 & 82.1 & 2.7 & 872 \\
\hline $10-$ Oct & 102 & 72.4 & 2.7 & 952 \\
\hline 10-Nov & 116 & 61.9 & 2.7 & 1,073 \\
\hline 10-Dec & 141 & 36.1 & 2.3 & 1,128 \\
\hline Total & 1,355 & 56.0 & 2.6 & 11,868 \\
\hline
\end{tabular}


Table 2.9. Measured performance of space conditioning and water heating at House 1, by $5^{\circ}$ outdoor air temperature bin

\begin{tabular}{|c|c|c|c|c|c|c|c|c|c|c|}
\hline \multicolumn{2}{|c|}{ Outdoor Air } & \multicolumn{3}{|c|}{ Heating } & \multicolumn{3}{|c|}{ Cooling } & \multicolumn{3}{|c|}{ DHW } \\
\hline $\begin{array}{c}\text { Bin } \\
\text { Mid- } \\
\text { Point } \\
\text { Temp } \\
\text { (F) } \\
\end{array}$ & $\begin{array}{c}\text { Bin } \\
\text { Time } \\
\text { (hr) }\end{array}$ & $\begin{array}{c}\text { Ave } \\
\text { “On” } \\
\text { EFT } \\
\text { (F) }\end{array}$ & $\begin{array}{l}\text { “On” } \\
\text { Time } \\
\text { (hr) }\end{array}$ & $\begin{array}{c}\text { Load } \\
\text { Met } \\
\text { (kBtu) }\end{array}$ & $\begin{array}{c}\text { Ave } \\
\text { “On” } \\
\text { EFT } \\
\text { (F) }\end{array}$ & $\begin{array}{c}\text { “On” } \\
\text { Time } \\
\text { (hr) }\end{array}$ & $\begin{array}{c}\text { Load } \\
\text { Met } \\
\text { (kBtu) }\end{array}$ & $\begin{array}{c}\text { Ave } \\
\text { “On” } \\
\text { EFT } \\
\text { (F) } \\
\end{array}$ & $\begin{array}{c}\text { “On” } \\
\text { Time } \\
\text { (hr) }\end{array}$ & $\begin{array}{c}\text { Load } \\
\text { Met } \\
\text { (kBtu) }\end{array}$ \\
\hline 7 & 6 & 37.9 & 4.4 & 93.3 & & & & 39.3 & 0.4 & 6.4 \\
\hline 12 & 27 & 38.9 & 23.8 & 479.6 & & & & 38.5 & 4.8 & 68.7 \\
\hline 17 & 121 & 39.6 & 88.6 & $1,694.7$ & & & & 38.5 & 14.0 & 196.3 \\
\hline 22 & 223 & 39.1 & 166.5 & $2,882.0$ & & & & 38.9 & 19.0 & 264.5 \\
\hline 27 & 435 & 37.9 & 364.5 & $5,915.9$ & & & & 37.4 & 56.2 & 761.9 \\
\hline 32 & 278 & 38.8 & 219.2 & $3,543.0$ & & & & 44.4 & 33.2 & 504.4 \\
\hline 37 & 881 & 39.3 & 638.1 & $10,085.9$ & & & & 40.8 & 112.0 & $1,599.3$ \\
\hline 42 & 500 & 42.2 & 174.9 & $2,656.9$ & & & & 47.9 & 51.1 & 801.9 \\
\hline 47 & 614 & 41.9 & 162.9 & $2,338.3$ & & & & 49.3 & 64.4 & $1,030.8$ \\
\hline 52 & 642 & 43.1 & 95.4 & $1,257.1$ & & & & 51.5 & 66.3 & $1,097.4$ \\
\hline 57 & 533 & 41.9 & 31.4 & 447.9 & 74.0 & 5.7 & 94.6 & 58.3 & 47.9 & 851.3 \\
\hline 62 & 590 & 41.9 & 14.2 & 172.2 & 74.8 & 31.0 & 503.9 & 63.5 & 47.0 & 865.9 \\
\hline 67 & 787 & 42.3 & 7.2 & 104.5 & 77.4 & 92.5 & $1,493.5$ & 66.7 & 61.2 & $1,162.4$ \\
\hline 72 & 993 & 44.3 & 4.5 & 41.7 & 80.4 & 252.8 & $4,124.0$ & 71.7 & 70.6 & $1,371.7$ \\
\hline 77 & 824 & 50.1 & 0.2 & 0.6 & 82.2 & 373.0 & $6,196.7$ & 75.9 & 66.5 & $1,290.6$ \\
\hline 82 & 641 & 45.0 & 0.2 & 3.4 & 81.5 & 379.7 & $6,474.0$ & 77.7 & 51.7 & 997.0 \\
\hline 87 & 438 & & & & 83.6 & 311.7 & $5,323.6$ & 81.9 & 28.9 & 572.7 \\
\hline 92 & 202 & & & & 85.2 & 176.7 & $3,127.1$ & 84.6 & 13.7 & 263.3 \\
\hline 97 & 26 & & & & 87.1 & 24.9 & 446.3 & & & \\
\hline 58 & 8,760 & 40 & 1,996 & 31,717 & 82 & 1,648 & 27,784 & 57 & 809 & 13,707 \\
\hline
\end{tabular}

Table 2.10. Measured performance of space conditioning and water heating at House 2, by $5^{\circ}$ outdoor air temperature bin

\begin{tabular}{|c|c|c|c|c|c|c|c|c|c|c|}
\hline \multicolumn{2}{|c|}{ Outdoor Air } & \multicolumn{3}{|c|}{ Heating } & \multicolumn{3}{|c|}{ Cooling } & \multicolumn{3}{|c|}{ DHW } \\
\hline $\begin{array}{c}\text { Bin } \\
\text { Mid- } \\
\text { Point } \\
\text { Temp } \\
\text { (F) } \\
\end{array}$ & $\begin{array}{c}\text { Bin } \\
\text { Time } \\
\text { (hr) }\end{array}$ & $\begin{array}{c}\text { Ave } \\
\text { “On” } \\
\text { EFT } \\
\text { (F) } \\
\end{array}$ & $\begin{array}{c}\text { “On” } \\
\text { Time } \\
\text { (hr) } \\
\end{array}$ & $\begin{array}{c}\text { Load } \\
\text { Met } \\
\text { (kBtu) } \\
\end{array}$ & $\begin{array}{c}\text { Ave } \\
\text { “On" } \\
\text { EFT } \\
\text { (F) } \\
\end{array}$ & $\begin{array}{c}\text { “On” } \\
\text { Time } \\
\text { (hr) } \\
\end{array}$ & $\begin{array}{c}\text { Load } \\
\text { Met } \\
\text { (kBtu) } \\
\end{array}$ & $\begin{array}{c}\text { Ave } \\
\text { “On” } \\
\text { EFT } \\
\text { (F) } \\
\end{array}$ & $\begin{array}{c}\text { “On” } \\
\text { Time } \\
\text { (hr) } \\
\end{array}$ & $\begin{array}{c}\text { Load } \\
\text { Met } \\
\text { (kBtu) } \\
\end{array}$ \\
\hline 7 & 6 & 39.4 & 5.5 & 129.1 & & & & 42.5 & 1.9 & 19.6 \\
\hline 12 & 27 & 40.7 & 25.7 & 604.4 & & & & 40.7 & 10.3 & 102.6 \\
\hline 17 & 121 & 40.6 & 114.6 & $2,638.1$ & & & & 39.5 & 19.1 & 197.2 \\
\hline 22 & 223 & 39.3 & 209.0 & $4,609.8$ & & & & 37.1 & 56.0 & 593.3 \\
\hline 27 & 435 & 37.8 & 393.2 & $8,240.0$ & & & & 44.8 & 40.2 & 472.3 \\
\hline 32 & 278 & 38.5 & 225.2 & $4,220.6$ & & & & 40.5 & 122.1 & $1,369.0$ \\
\hline 37 & 881 & 39.2 & 715.4 & $13,135.1$ & & & & 47.5 & 72.4 & 906.1 \\
\hline 42 & 500 & 42.7 & 248.0 & $4,421.7$ & & & & 48.2 & 75.8 & 973.7 \\
\hline 47 & 614 & 42.0 & 252.7 & $4,435.8$ & & & & 50.6 & 77.6 & $1,035.5$ \\
\hline 52 & 642 & 43.8 & 178.5 & $3,206.3$ & & & & 57.1 & 56.5 & 797.2 \\
\hline 57 & 533 & 43.1 & 63.7 & $1,133.9$ & 68.7 & 1.0 & 19.3 & 62.5 & 49.7 & 733.9 \\
\hline 62 & 590 & 45.0 & 29.8 & 543.5 & 63.2 & 5.8 & 109.4 & 64.2 & 74.0 & $1,101.4$ \\
\hline 67 & 787 & 45.0 & 15.3 & 294.1 & 69.2 & 36.8 & 672.8 & 71.8 & 74.9 & $1,094.3$ \\
\hline 72 & 993 & 47.2 & 6.9 & 128.8 & 78.7 & 164.2 & $2,893.8$ & 74.1 & 69.0 & 993.5 \\
\hline 77 & 824 & 49.7 & 2.6 & 50.6 & 80.5 & 313.2 & $5,486.4$ & 73.9 & 60.1 & 860.9 \\
\hline 82 & 641 & 50.2 & 1.8 & 35.1 & 79.0 & 362.9 & $6,486.3$ & 78.3 & 33.4 & 467.5 \\
\hline 87 & 438 & 46.2 & 0.3 & 5.2 & 81.0 & 285.8 & $5,151.8$ & 81.6 & 18.0 & 266.3 \\
\hline 92 & 202 & & & & 83.1 & 164.7 & $2,986.3$ & 83.5 & 0.7 & 10.0 \\
\hline 97 & 26 & & & & 85.1 & 25.1 & 476.9 & & & \\
\hline 58 & 8,760 & 40 & 2,488 & 47,827 & 80 & 1,360 & 24,283 & 56 & 912 & 11,994 \\
\hline
\end{tabular}




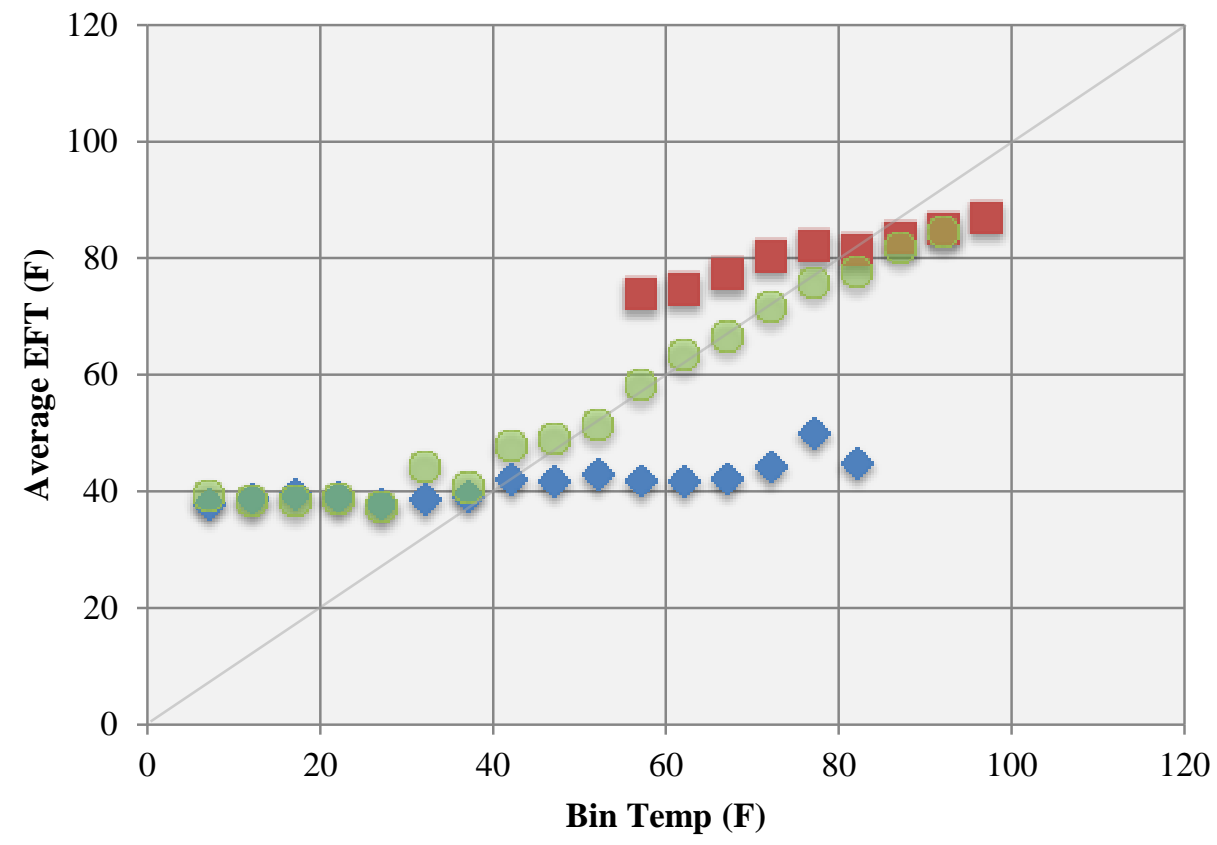

Average "on" EFT (Heating)

Average "on" EFT (Cooling) Average "on" EFT (DHW)

Figure 2.16. Average “on" EFTs as a function of bin mid-point temperature for House 1.

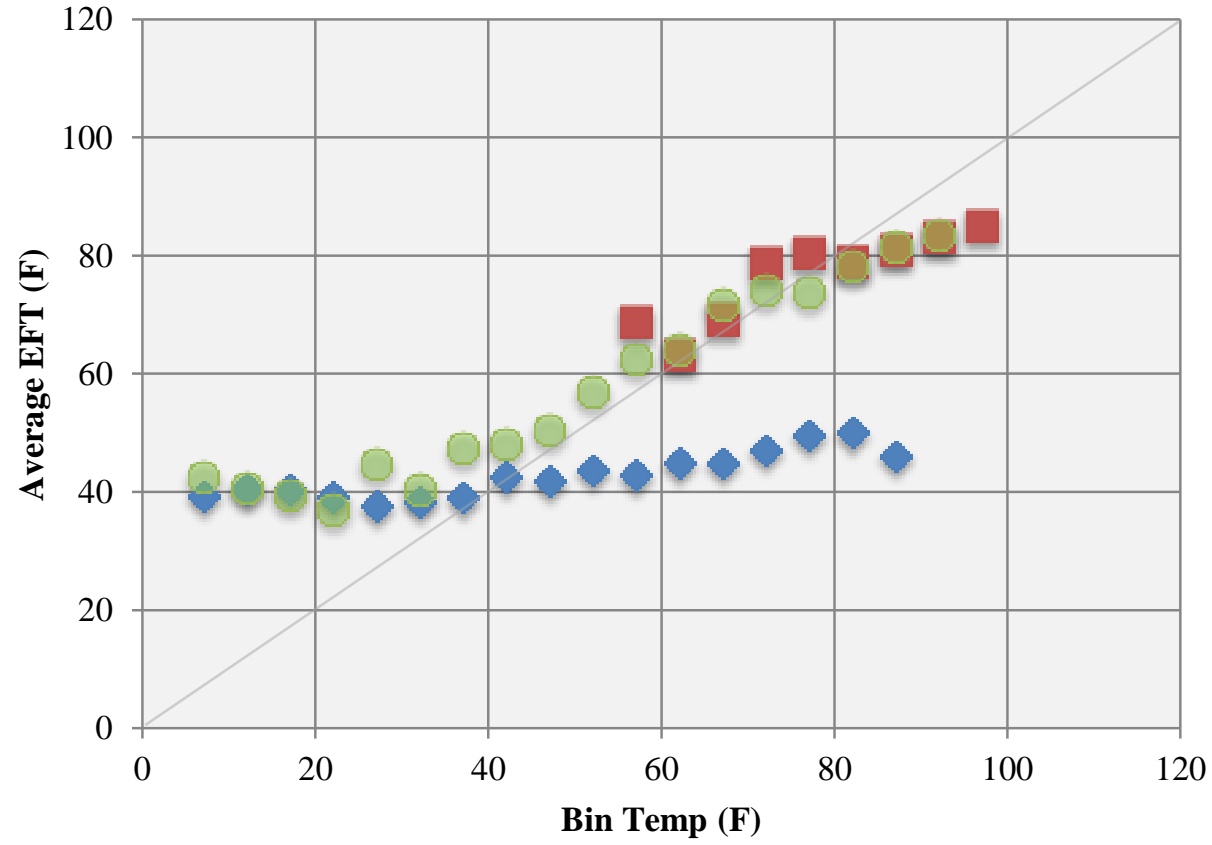

$\checkmark$ Average "on" EFT (Heating) Average "on" EFT (Cooling) A Average "on" EFT (DHW)

Figure 2.17. Average "on" EFTs as a function of bin mid-point temperature for House 2. 
Figure 2.18 shows hourly trend plots for several variables for the period January through November 2010 for House 1. The figure shows the entering and leaving fluid temperature for the WAHP, outside air temperature, undisturbed (far field) and disturbed (in excavation) underground temperature, and delta $\mathrm{T}$ (i.e., entering fluid temperature minus leaving fluid temperature). The periods of cooling only, heating only, and mixed cooling/heating are also noted. Outdoor air temperature ranges from 8 to $96^{\circ} \mathrm{F}$, while the undisturbed underground temperature at a $5 \mathrm{ft}$ depth ranges from 45 to $78^{\circ} \mathrm{F}$, which explains the potential for horizontal GSHP systems to perform better than air-source heat pumps. Also note that outdoor air temperature can fluctuate by over $20^{\circ} \mathrm{F}$ in a day, while soil temperature at a $5 \mathrm{ft}$ depth changes very little in any given day. As expected, the absolute value of delta T across the FHX/HGHX in cooling mode of $5.7^{\circ} \mathrm{F}$ exceeds the heating mode value of $3.7^{\circ} \mathrm{F}$, because in cooling mode heat rejection includes the load met plus WAHP power consumption, whereas in heating mode the heat extraction equals the load met less the WAHP power consumption.

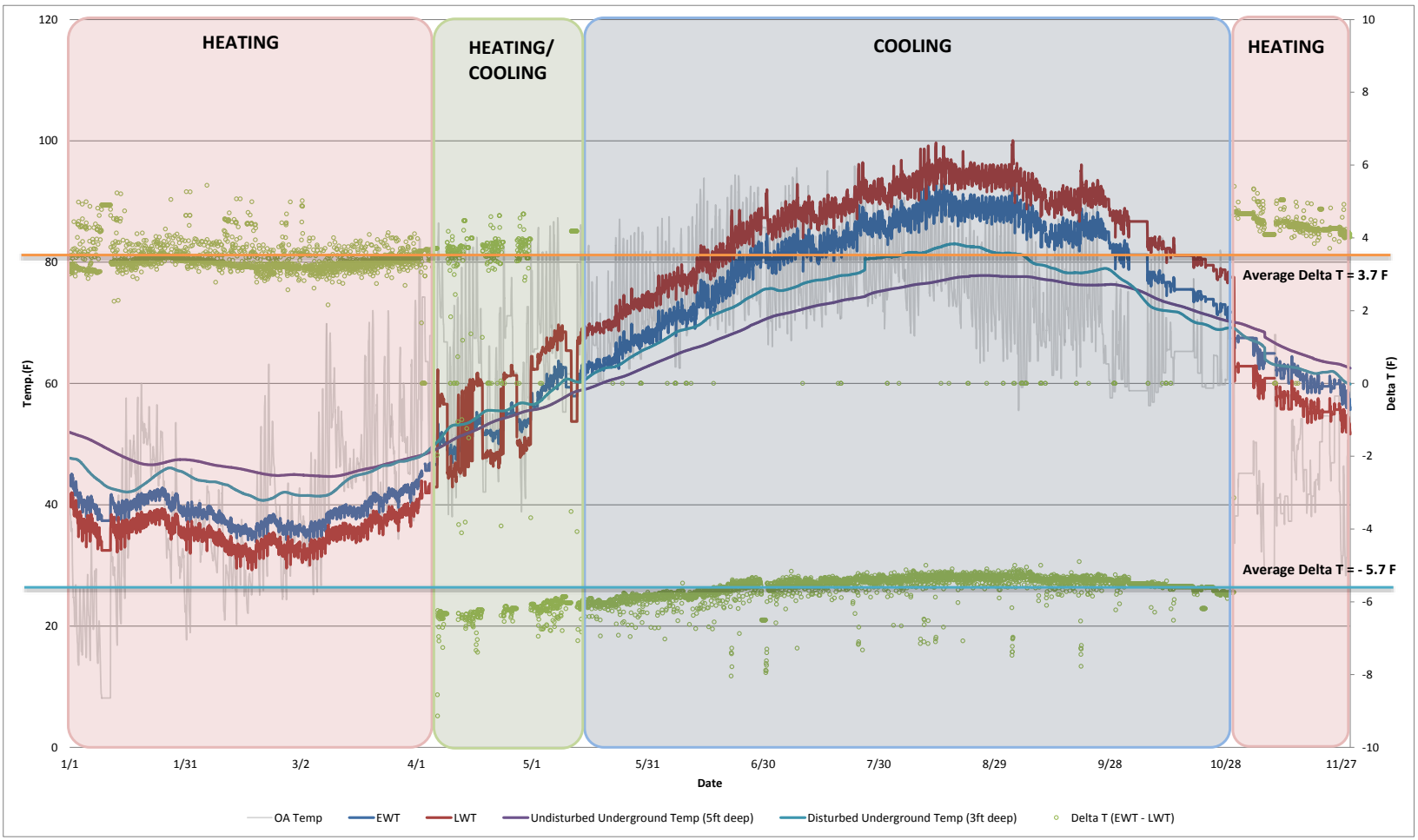

Figure 2.18. Hourly trends for outdoor air (OA), entering and leaving water/fluid temperature (EWT or LWT), undisturbed ground and disturbed ground temperatures, and delta T (EWT minus LWT), at House 1.

Monthly heat transfer between the WAHP and WWHP and the ground (rejection or extraction) at houses 1 and 2 is summarized in tables 2.11 and 2.12. This same data is graphed in figures 2.19 and 2.20. Net heat transfer to the ground on an annual basis was nearly zero (well balanced) at House 1, and showed a modest net extraction at House 2. If the ground heat exchangers served only space conditioning (rather than also serving water heating), both houses would have had a modest annual net heat rejection. 
Table 2.11. Monthly heat transfer between heat pumps and the ground at House 1 (kBtu/month)

\begin{tabular}{l|rrrr}
\hline & $\begin{array}{r}\text { WAHP } \\
\text { heat rejection }\end{array}$ & $\begin{array}{r}\text { WAHP } \\
\text { heat extraction }\end{array}$ & $\begin{array}{r}\text { WWHP } \\
\text { heat extraction }\end{array}$ & $\begin{array}{c}\text { Sum of } \\
\text { extraction/rejection }\end{array}$ \\
\hline Jan & 0 & 6,504 & 986 & 7,490 \\
Feb & 0 & 6,578 & 870 & 7,448 \\
Mar & 0 & 4,688 & 963 & 5,651 \\
Apr & -866 & 650 & 802 & 586 \\
May & $-3,445$ & 6 & 853 & $-2,586$ \\
Jun & $-7,123$ & 0 & 833 & $-6,290$ \\
Jul & $-9,220$ & 0 & 739 & $-8,481$ \\
Aug & $-10,278$ & 0 & 902 & $-9,376$ \\
Sep & $-6,422$ & 0 & 997 & $-5,425$ \\
Oct & -880 & 46 & 1,046 & 213 \\
Nov & 0 & 1,379 & 994 & 2,372 \\
Dec & 0 & 7,261 & 1,019 & 8,280 \\
Total & $\mathbf{7 8 , 2 3 3}$ & $\mathbf{2 7 , 1 1 2}$ & $\mathbf{1 1 , 0 0 3}$ & $\mathbf{- 1 1 8}$ \\
\hline
\end{tabular}

Table 2.12. Monthly heat transfer between heat pumps and the ground at House 2 (kBtu/month)

\begin{tabular}{l|rrrr}
\hline & $\begin{array}{r}\text { WAHP } \\
\text { heat rejection }\end{array}$ & $\begin{array}{r}\text { WAHP } \\
\text { heat extraction }\end{array}$ & $\begin{array}{c}\text { WWHP } \\
\text { heat extraction }\end{array}$ & $\begin{array}{c}\text { Sum of } \\
\text { extraction/rejection }\end{array}$ \\
\hline Jan & 0 & 8,925 & 714 & 9,639 \\
Feb & 0 & 8,014 & 723 & 8,736 \\
Mar & 0 & 5,658 & 916 & 6,575 \\
Apr & -930 & 1,376 & 754 & 1,200 \\
May & $-3,395$ & 89 & 807 & $-2,499$ \\
Jun & $-5,753$ & 0 & 700 & $-5,052$ \\
Jul & $-9,961$ & 0 & 663 & $-9,298$ \\
Aug & $-10,491$ & 0 & 561 & $-9,930$ \\
Sep & $-5,797$ & 0 & 709 & $-5,088$ \\
Oct & -330 & 112 & 755 & 537 \\
Nov & 0 & 2,496 & 841 & 3,337 \\
Dec & 0 & 9,335 & 845 & 10,180 \\
Total & $-36,658$ & $\mathbf{3 6 , 0 0 5}$ & $\mathbf{8 , 9 8 9}$ & $\mathbf{8 , 3 3 6}$ \\
\hline
\end{tabular}




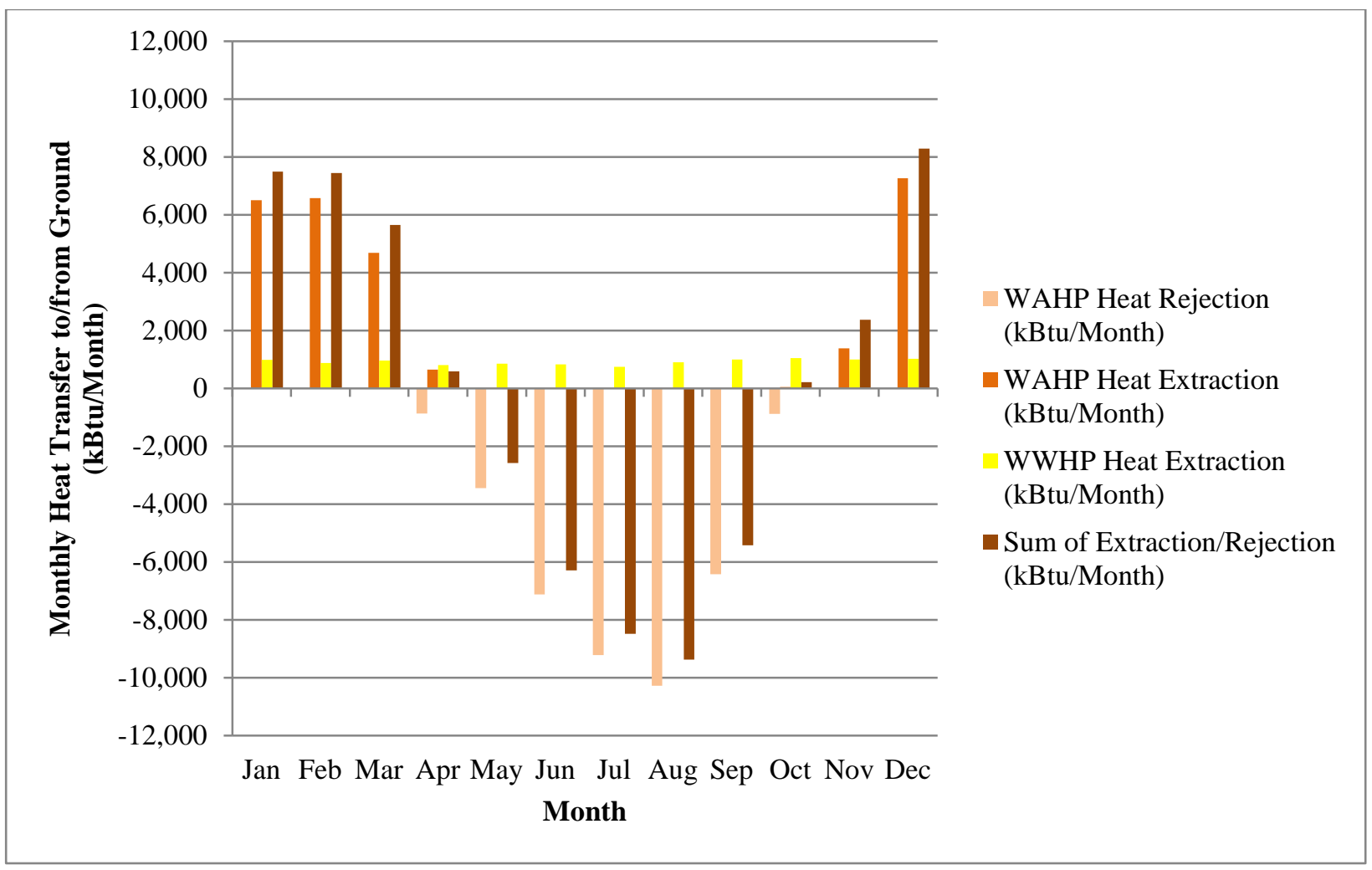

Figure 2.19. Monthly heat transfer between heat pumps and the ground at House 1 .

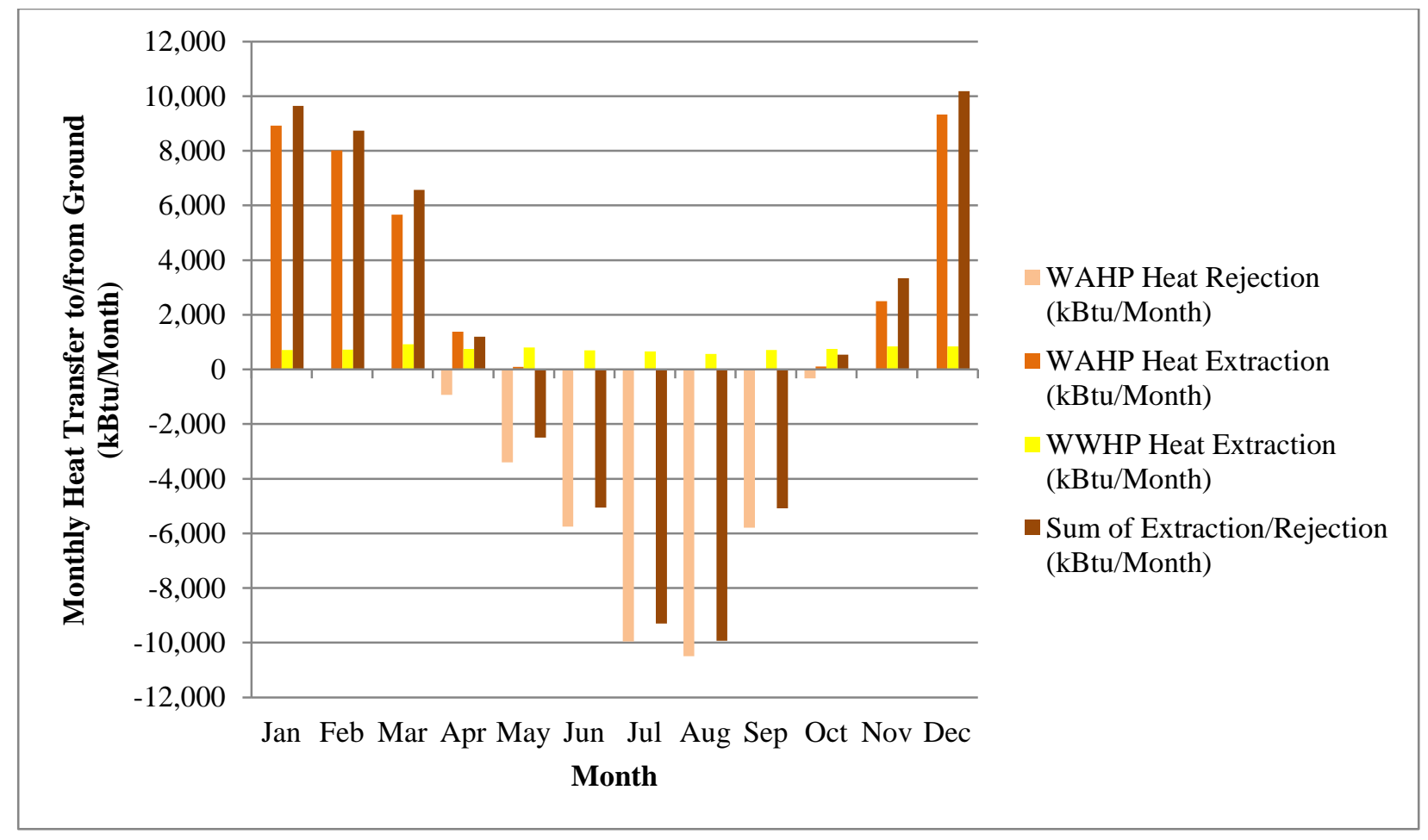

Figure 2.20. Monthly heat transfer between heat pumps and the ground at House 2 . 


\section{NUMERICAL MODEL AND DESIGN TOOL DEVELOPMENT AND VALIDATION}

\subsection{Objectives and Approach}

A key objective of this research project was to develop and validate the necessary energy performance models and design tools so that GSHP systems using FHX (ground heat exchangers installed in the overcut around basement walls) or hybrid FHX/HGHX (with some of the ground heat exchangers installed in utility, footer drain, or supplemental trenches) can be designed and deployed with confidence wherever they are feasible. The project focused on the greatest technical challenge, which was developing and validating models and design tools for FHX. (Ground heat exchangers in utility and footer drain trenches are essentially no different from HGHX in supplemental trenches, and models and design tools for HGHX already exist.) This research project does not explicitly address ground heat exchangers installed below the basement floor, which have very simple geometry and boundary conditions, and we felt that this capability could be added to the models and design tools later. In fact, the computationally efficient 3D model (described in Section 3.4) can model ground heat exchangers below the basement floor.

Some of the factors that make developing models and design tools for FHX challenging are illustrated in Figure 3.1. A potential problem unique to FHX is that the presence of the heat exchanger pipes near the basement wall may change the temperatures of the earth near the wall and wall heat flux significantly, affecting the design heating and cooling loads of the conditioned basement, or the temperature in unconditioned basements and hence the design heating and cooling loads of the conditioned spaces above. Another potential problem unique to FHX is that pipe and wall heat flux may be significantly different around outside corners or inside corners than along straight sections of the basement walls, requiring 3D models for accurate characterization.

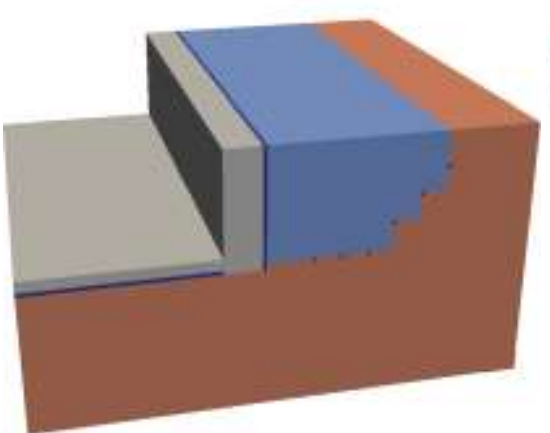

Side Wall

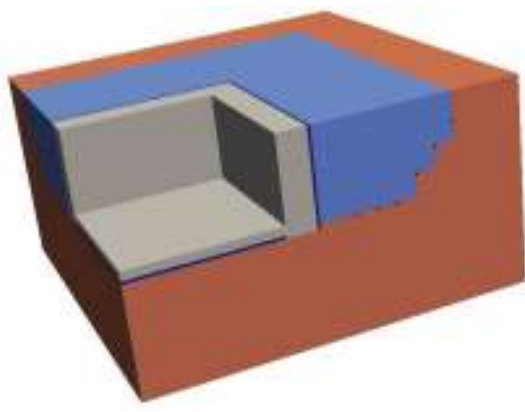

Outside Corner

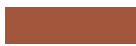

Unaffected Ground

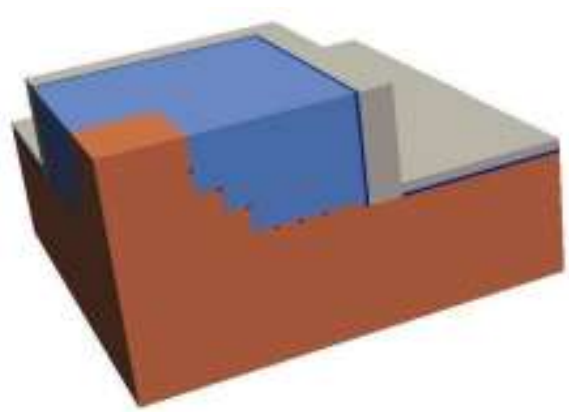

Inside Corner

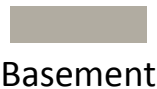

Affected Ground

Figure 3.1. The variability of building configurations and potential effects of FHX on earth and building temperatures presented challenges in developing and validating FHX models and design tools.

Other confounding factors for FHX, which also impact HGHX and may be inadequately addressed in existing HGHX models and design tools, are illustrated in Figure 3.2. These include characterization of undisturbed soil temperature variation with depth, multi-mode heat transfer [convection, evapo- 
transpiration, thermal (long-wave) radiation, and solar (short-wave) radiation] between the ground and outdoor air, diurnal or seasonal changes in multi-mode ground-air heat transfer (as grasses go dormant, are covered with snow, or are shaded by the house or tree canopy), and the impact of soil freezing, whether around the pipes or as the result of the naturally penetrating frost line in winter.

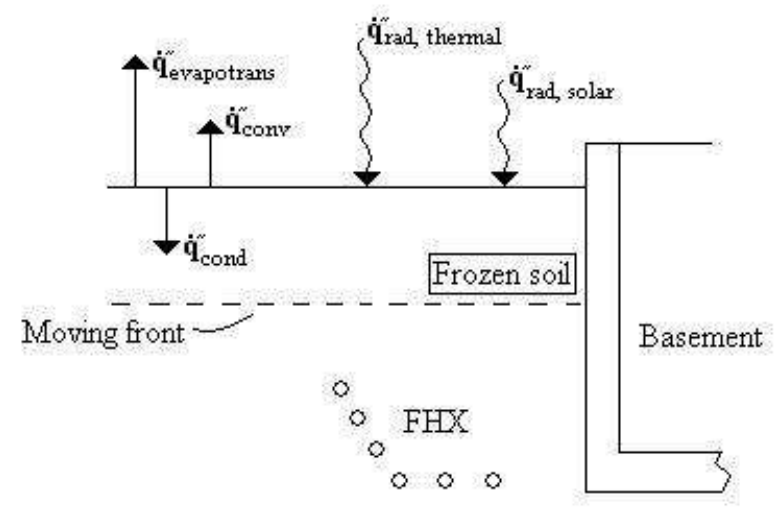

Figure 3.2. Some of the factors that influence FHX performance include soil temperature variation with depth, and multi-mode heat transfer. (Source: Cullin et al. 2012.)

The general project approach was to develop a suite of research-grade models that could address as many of these factors as possible, validate the models with measured data, and as part of the validation process determine which factors were important enough or feasible to retain in the EnergyPlus-based energy model and the design tool. In reality, models can always be made more sophisticated and computationally intensive. But as a practical matter, FHX is a technology intended for housing and light commercial buildings, and if the models and tools for FHX are too time consuming or difficult for practitioners in these fields to use, FHX will not be successful in the market. Therefore the project was designed to make practical tradeoffs. For example, if input parameter uncertainty for a confounding factor has greater impact on results (performance predictions, design calculations) than use of a simplified approach (which is unable to consider the confounding factor) versus a detailed one, we go with the simplified approach.

Reducing new technologies to practice often involves developing application tools that are simple enough for practitioners to use. Technology applications designed with simplified tools can be just as successful as those designed with detailed tools, especially when the guidance for selecting inputs for the simplified tools is based on analysis of data from measurements or detailed tools.

\subsection{Research-Grade, 2-Dimensional, Fine-Grid, Finite-Volume, FHX Model}

A detailed numerical model based on the 2D finite-volume method, and implemented in HVACSIM+ with hourly time steps, was developed as part of this project (Xing 2010; Xing et al. 2011). The model considers a wide variety of factors including thermal interaction between the FHX and basement wall, multi-mode ground-outdoor air heat transfer [convection, evapo-transpiration, thermal (long-wave) radiation, and solar (short-wave) radiation], soil heat transfer, soil freezing, conduction through the pipe wall, and convection between the pipe wall and circulating fluid.

As shown in Figure 3.3, the simulated soil domain is bounded by the earth's surface and the basement wall and floor. This 2D model, with the soil domain in a plane perpendicular to the piping, represents a $3 \mathrm{D}$ reality by assuming there is no heat transfer through the soil along the length of the piping and that the effect of basement corners is unimportant. In other words, soil temperature will not change in the third 
dimension. However, since fluid temperature does change along the length of the piping, the fluid temperature used in the $2 \mathrm{D}$ soil domain cross section is the average fluid temperature along the length of the piping. In essence, the FHX is treated as a soil-fluid heat exchanger in the 3D soil domain by means of the effectiveness-NTU method (Xing 2010).

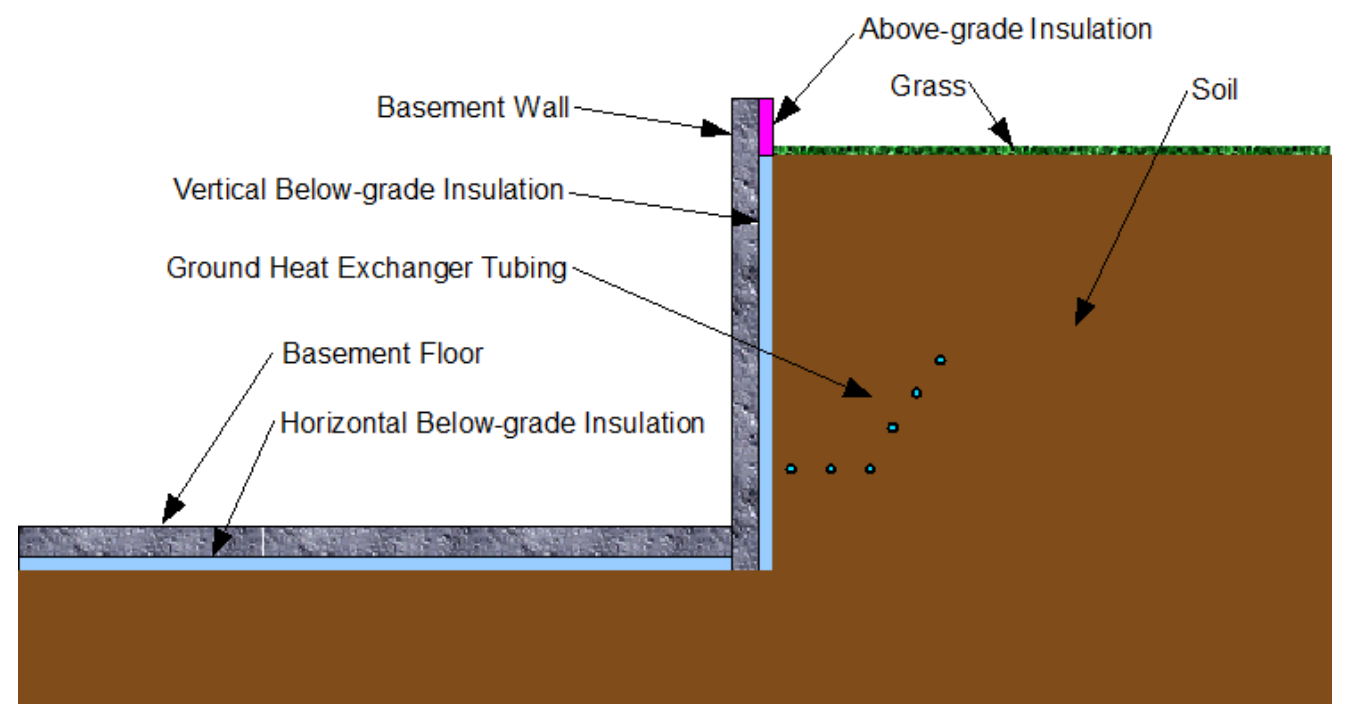

Figure 3.3. Side wall FHX 2D cross section. (Source: Spitler et al. 2010.)

The model was originally intended to use a coarse grid, but as testing and validation went on, it became apparent that a finer grid, as shown in Figure 3.4, was needed for accuracy. Although this model was too slow for EnergyPlus implementation, it served as an extremely useful research tool. After validation, this model was used to investigate the accuracy of the analytical solution used in the FHX design tool (see Section 3.5). It was also used to investigate the geographic range of feasibility of GSHP systems using pure FHX systems in single-family residences in the United States (see Section 3.6). In addition, this model was essential for determining which phenomena needed to be modeled by the 3D models explained later.

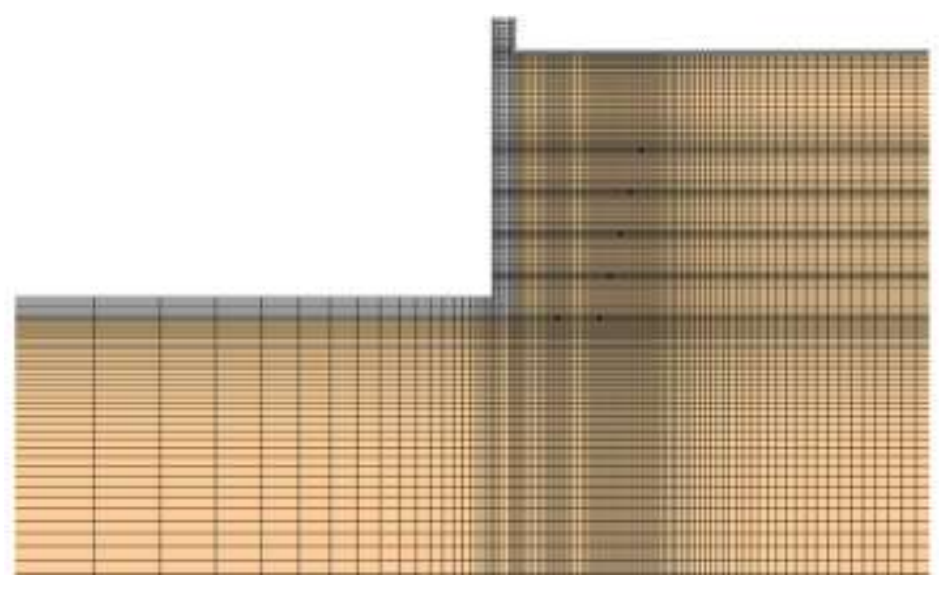

Figure 3.4. Non-uniform fine grid required for 2D finite-volume model accuracy. (Source: Xing et al. 2011.)

The model was validated with one year of experimental data collected at House 1. The model shows good agreement with the experimental data with minor discrepancies due to the approximations explained 
above and assumptions such as constant soil moisture content throughout the year, uniform evapotranspiration over the seasons, and lack of ground shading in the model. The daily average heat pump entering fluid temperatures (EFTs) predicted by the model and measured at House 1 are shown in Figure 3.5. The predicted and measured daily average heat pump EFTs are typically within $1.8^{\circ} \mathrm{F}$ of each other.

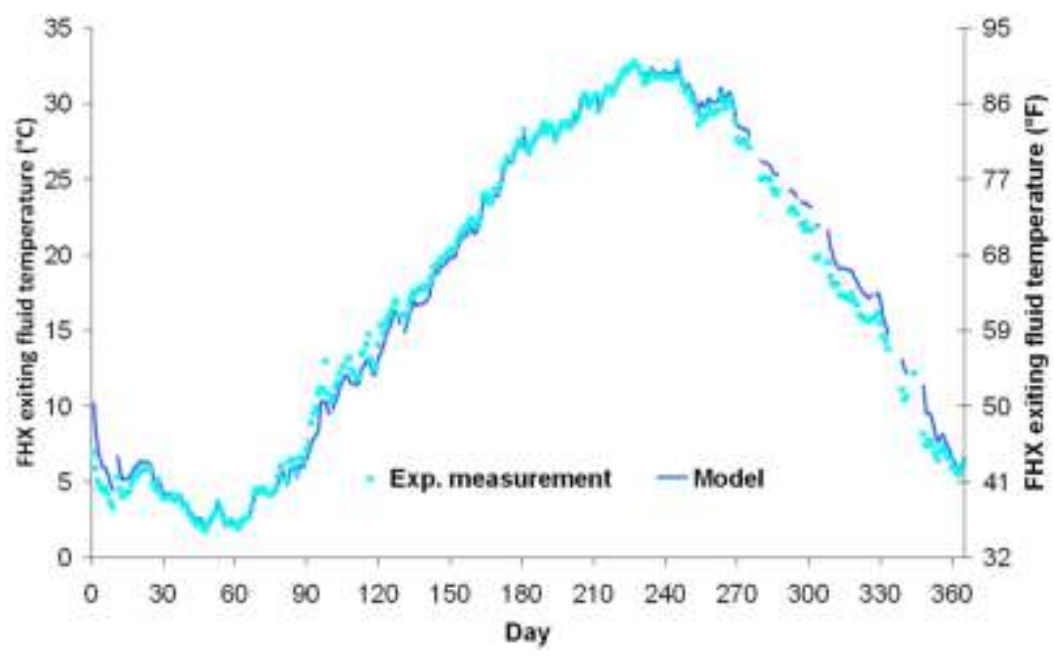

Figure 3.5. Daily average measured and modeled heat pump entering (FHX exiting) fluid temperature using 2D model. (Source: Xing et al. 2011.)

\subsection{Research-Grade, Multi-Block, Boundary-Fitted, 3-Dimensional, Finite-Volume, FHX Model}

A research-grade, multi-block, boundary-fitted, 3D, finite-volume, numerical model for general use known as Gems3D (General Elliptical Multi-Block Solver in 3 Dimensions) was previously developed (Rees, Spitler, and Xiao 2002 is the original Gems2D citation; He, Rees, and Shao 2011 describes the extension of Gems2D to Gems3D). The general Gems3D model was also previously applied to simulate building-ground thermal coupling for slab-on-grade construction and found to compare favorably with other models via the International Energy Agency Annex 43 BESTEST evaluation process (De Montfort University 2009).

As part of this project Gems3D has been significantly restructured to improve computation speed, allow multiple instances of FHX in a modeled application (e.g., FHX along basement side walls, around corners), and to automatically (i.e., without modeler involvement) generate the meshes needed for the method to accurately simulate specific FHX problems. The project team refers to the revised Gems3D as GHX3D, which was implemented into a research version of EnergyPlus (Rees 2011).

Some of the 3D geometries that can be simulated with this model are shown in Figure 3.6. This is a true 3D model. Rather than solve a 2D soil domain against the average fluid temperature along the length of the piping, this model allows heat transfer in all three dimensions, calculates different fluid and soil temperatures in all three dimensions, and can consider basement outside and inside corners as well as basement side walls. 


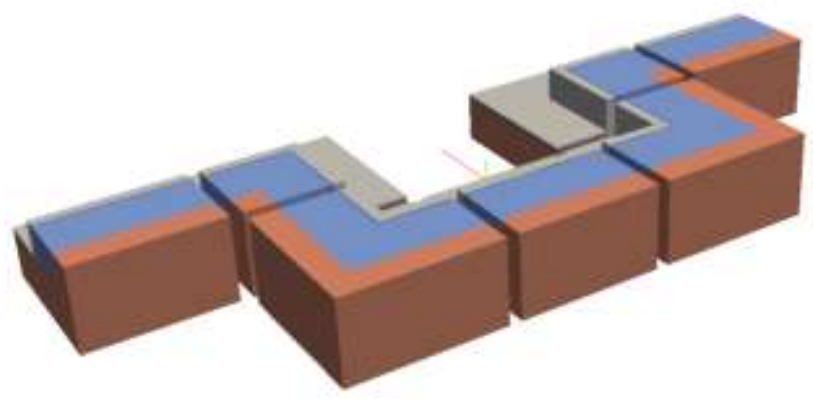

Figure 3.6. FHX side walls, outside corners, and inside corners can be combined to represent a complex basement plan. (Source: Fan and Rees 2011.)

Initially it was thought that GHX3D might be fast enough for the public version of EnergyPlus but this was not the case. Instead GHX3D within a research version of EnergyPlus was used to test other source codes, one of which became the computationally efficient model included in the public version of EnergyPlus and described in the next section.

Considerable project effort went into developing a 3D FHX mesh generation tool. The tool is based on the principle of constructing multi-block meshes for a 2D plan view and then "extruding" the mesh along vectors into the third dimension (Rees 2011). The FHX mesh generation tool requires a small number of FHX input parameters (e.g., for each pipe the depth below ground surface, horizontal distance from basement wall, diameter, etc.) and uses algorithms to translate the inputs into the required mesh geometry for 3D finite-volume modeling. The resulting tool can generate mesh for FHX along basement side walls or around inside corners and outside corners (Fan and Rees 2011). An example of the latter is shown in Figure 3.7. The automated FHX mesh generation capability was demonstrated as part of GHX3D within a research version of EnergyPlus, and relevant portions were retained in the computationally efficient FHX model described in the next section.
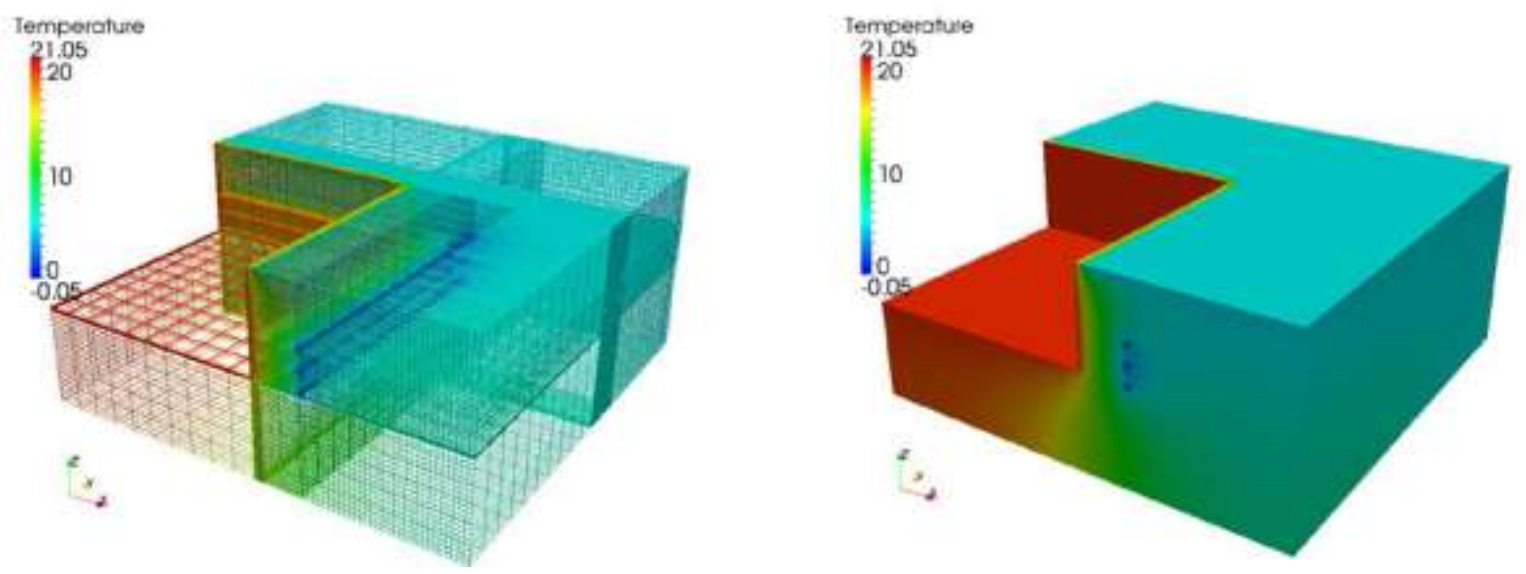

Figure 3.7. Examples of automatically generated 3D model mesh and results for an outside corner FHX segment.

The GHX3D-based model was validated with one year of experimental data collected at House 1 (Rees and Fan 2011). As can be seen in Figure 3.8, the model shows excellent agreement with the experimental data. 


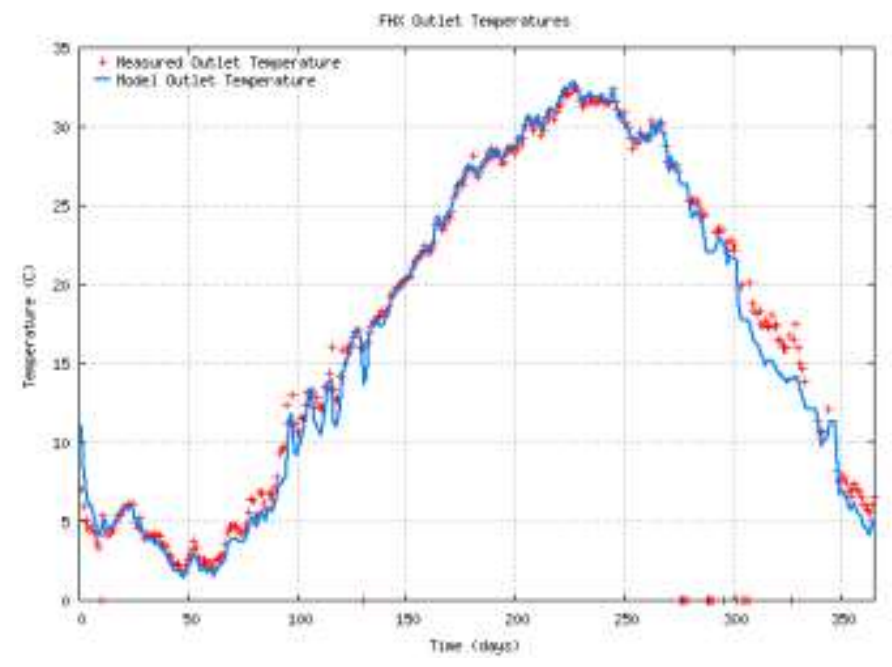

Figure 3.8. Daily average measured and modeled heat pump entering (FHX exiting) fluid temperature using 3D model. (Source: Rees and Fan 2011.)

Once validated, EnergyPlus with GHX3D was used to investigate whether FHX pipe heat flux varied significantly around outside corners or inside corners versus along straight basement side walls. It was concluded that with a reasonable level of insulation around the outside of the basement wall, the 3D heat transfer effects do not significantly impact FHX pipe heat flux. In other words, the effect of basement corners on FHX performance is unimportant (Rees and Fan 2011). This was merely an assumption of the $2 \mathrm{D}$ model described in the previous section. The work with this $3 \mathrm{D}$ model validated the assumption. It should be noted, however, that corners are important for the calculation of basement heat flux and the inability to address corners remains a weakness of 2D models for building load calculation.

After determining that GHX3D integrated into EnergyPlus would not be fast enough for non-research purposes, considerable project resources were expended in the search for a more computationally efficient yet accurate 3D approach. The project team investigated the suitability of an approach developed at Chalmers University, Sweden, known as Dynamic Thermal Network (DTN) modeling (PhD thesis by Wentzel 2005). A significant advantage of this approach over other weighting factor methods is that complex 3D geometries can be dealt with as easily as one-dimensional surfaces. With this approach a numerical model is used to derive a series of temperature weighting factors that enable a fast simulation thereafter. While trying to implement the approach for FHX it was discovered that excessive numerical model run time was required to generate the necessary step response data (the step responses must be simulated over approximately 150 years for FHX). Therefore using DTN as the basis for an EnergyPlus model was not feasible without a library of pre-calculated response factors, which was beyond the scope of this project to create. The work done attempting to apply the DTN approach to FHX is further described elsewhere (Fan, Rees, and Spitler 2011; Fan and Rees 2011).

In parallel with the investigation of the DTN approach, the project team investigated the 3D dualcoordinate-system approach, which is described in the next section and was ultimately selected as the computationally efficient EnergyPlus model.

\subsection{Computationally Efficient, 3-Dimensional, Dual-Coordinate-system, Finite-Volume, FHX Model}

A 3D, dual-coordinate-system (DCS), finite-volume, detailed numerical model implemented in the October 2011 EnergyPlus Version 7 public release was developed as part of this project (Lee 2011a, Lee 2011b, Lee 2011c). The model considers a wide variety of factors including thermal interaction between 
the FHX and basement wall, multi-mode ground-outdoor air heat transfer [convection, evapotranspiration, thermal (long-wave) radiation, and solar (short-wave) radiation], soil heat transfer, soil freezing, conduction through the pipe wall, and convection between the pipe wall and circulating fluid.

The computational efficiency of the DCS approach is primarily explained by two features of the model. First, the DCS approach focuses the computational effort near the pipes where it is most needed. A coarse Cartesian coordinate system is used to solve the slow-moving ground heat transfer. Then, within the coarse cells where the pipes reside (i.e., pipe cells), a radial coordinate system is configured around the pipe. This enables the use of a fine mesh in the near-pipe region where there is fast-moving heat transfer, and a much coarser mesh everywhere else in the ground. The second feature enhancing computational speed is the use of segregated iteration loops. An outer iteration loop is provided to simulate the coarsegrid Cartesian mesh and an inner iteration loop is provided to simulate the fine-grid radial mesh near the pipes. The outer loop generally converges within one or two iterations in each time step whereas the "pipe cells" may require much more iteration. With segregated iteration, any additional iteration only occurs in the region where convergence requires it. EnergyPlus using this model is capable of completing annual simulations of an FHX thermally coupled to a basement in less than two minutes on a modern PC.

This model is 3-dimensional in the sense that heat can flow between volumes in any direction. However, complex geometries such as FHX around outside corners and inside corners of basement walls are not simulated. As described in the previous section, these corner effects add significantly to computational time and model input file assembly effort, without significantly changing FHX pipe heat flux predictions.

As implemented in EnergyPlus, the model allows multiple instances of FHX (along basement side walls, below basement floor), which thermally interact with the basement, and multiple instances of conventional HGHX, which do not. These segments can be appropriately connected to represent the overall ground heat exchanger for the specific application. The model also simulates the pipe circuiting effects realistically by allowing fluid to flow in the various pipes in different directions for any given segment, and to be linked as desired to the pipes in the adjacent segments.

The model was validated with one year of experimental data collected at House 1. As can be seen in Figure 3.9, the model shows better agreement with the experimental data than the 2D model described in Section 3.2.

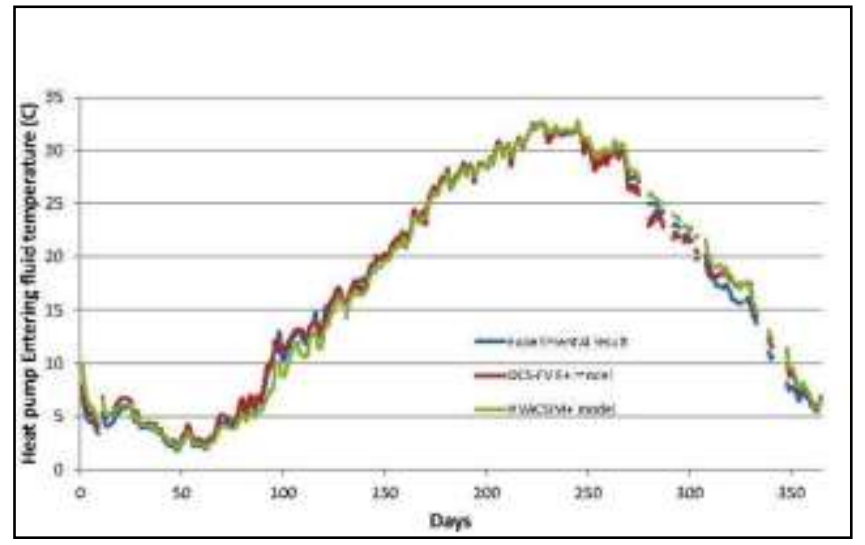

Figure 3.9. Daily average measured and modeled heat pump entering (FHX exiting) fluid temperature (DCS 3D and 2D models shown). (Source: Lee and Xing 2011.) 


\subsection{Practical FHX Design Tool Implemented in Excel}

A practical FHX design tool implemented in Excel using Visual Basic for Applications (VBA) was developed as part of this project, and is documented in the form of an FHX design tool user's manual (Oklahoma State University 2011). Analytical solutions (Xing 2010) form the technical basis for the FHX design tool. Using the design tool, sizing the FHX for a residential application can be accomplished in approximately 5 minutes (Xing, Spitler, and Cullin 2012).

Analytical models based on superposition of line sources and sinks, including mirror image sources and sinks, have been used successfully for years to model conventional HGHX for sizing purposes. This approach is applied to FHX. The analytical approach ignores corner effects and soil freezing, and assumes the basement wall is adiabatic and infinite in the vertical direction, the ground surface is isothermal, and the effect of changing weather conditions can be modeled with a simple approximation of undisturbed ground temperature (Kusuda and Achenbach 1965) rather than a heat balance at the ground surface.

The FHX design tool allows users to perform a simulation of the FHX to determine the monthly average and peak fluid temperatures entering the heat pump. For design purposes, the minimum and maximum heat pump EFTs are the key design constraints that drive the sizing of the ground heat exchanger. By changing the length of the FHX, the user can limit heat pump EFT within the allowable bounds. Since not all houses will have adequate ground heat exchanger capacity solely with an FHX, in cases where the maximum FHX size is still inadequate, the design tool can automatically determine the additional HGHX (placed in series with the FHX) that is required to keep heat pump EFT within the allowable bounds. As explained previously in this report, the additional HGHX trench length can be provided by construction excavations (e.g., utility trenches) or supplemental trenches. The current version of the design tool is unable to model FHX under the basement floor, but this capability could be added in the future.

The FHX design tool requires as inputs the locations and dimensions of the FHX piping, pipe and soil thermal properties, specification of the working fluid, monthly average and peak space heating and cooling loads, duration of heating and cooling peak loads, monthly average water heating loads (if served by GSHP), heat pump performance characteristics, and simulation duration. The user clicks the "simulation" button on the spreadsheet to perform the simulation for the length of time entered (24 months recommended, using the results from the second year). The FHX design tool outputs monthly month-end values for (1) mean fluid temperature in the ground heat exchanger (averaged over the length), (2) mean heat pump EFT (i.e., mean temperature exiting the ground heat exchanger in response to the total monthly space conditioning and water heating load), (3) peak maximum heat pump EFT (in response to the peak cooling load occurring for the specified duration at end of month), and (4) peak minimum heat pump EFT (in response to the peak heating load occurring for the specified duration at end of month).

After validation with one year of experimental data collected at House 1, the numerical model described in Section 3.2 was used to benchmark the FHX design tool (Xing, Spitler, and Cullin 2010; Xing, Spitler, and Cullin 2012). Comparisons involved running both the numerical and analytical (i.e., the design tool) models over a two year period, and comparing second year results (differences from simulating for a third year were negligible). Both models were iterated to determine the FHX lengths that resulted in heat pump EFTs reaching either the high or low bound of the allowable temperature range of 32 to $104^{\circ} \mathrm{F}$. In order to compare the models over a range of conditions, a typical house case was investigated at six different locations representing six climates in a commonly used climate classification scheme (Briggs, Lucas, and Taylor 2003a, 2003b).

It was found that in five of the six climates, the analytical model used by the FHX design tool oversized the FHX by 17 to $19 \%$ compared to the numerical model. The FHX was oversized $29 \%$ in the remaining climate. Given the inherent uncertainties in design inputs such as building loads and soil thermal properties, this level of accuracy in a simplified FHX design method is acceptable. 
As a further validation of the design tool, the "as-built" design values from House 1 were used to generate the inputs required for the design tool analysis. The input parameters describing the hybrid FHX/HGHX application at House 1 are summarized in Table 3.1. As described in Section 2.4, the averages of pipe depth and pipe distance from the basement wall over the $100 \mathrm{ft}$ FHX excavation, for each of the six pipes, were generated using the 3D CAD model. Other inputs required by the design tool, such the heat pump performance data, monthly cooling and heating loads, and domestic water heating loads, are documented previously in this report. With these inputs, the design tool estimated maximum and minimum EFTs of $96^{\circ} \mathrm{F}$ and $29^{\circ} \mathrm{F}$, respectively. By varying HGHX excavation length and re-running the design tool, it was estimated that the total House 1 excavation length would have to be increased from $300 \mathrm{ft}$ to $369 \mathrm{ft}$ in order for the design tool to output the measured maximum and minimum EFTs. In other words, the design tool calculation oversized the hybrid FHX/HGHX excavation length by $23 \%$ compared to the House 1 experiment, which is consistent with the findings relative to the numerical model described above.

Table 3.1. Design tool input parameters for the as-is FHX/HGHX at House 1

\begin{tabular}{|c|c|c|}
\hline \multicolumn{3}{|c|}{ System and foundation heat exchanger (FHX) input parameters } \\
\hline Thermal conductivity of the soil & 0.70 & $\mathrm{Btu} /\left(\mathrm{hr}-\mathrm{ft}-{ }^{\circ} \mathrm{F}\right)$ \\
\hline Specific heat of the soil & 0.25 & $\mathrm{Btu} / \mathrm{lb}-{ }^{\circ} \mathrm{F}$ \\
\hline Density of the soil & 120.0 & $\mathrm{lb} / \mathrm{ft}^{3}$ \\
\hline Undisturbed ground temperature & 61.0 & ${ }^{\circ} \mathrm{F}$ \\
\hline Surface amplitude & 22.0 & ${ }^{\circ} \mathrm{F}$ \\
\hline Volumetric flow rate & 6.0 & $\mathrm{Gal} / \mathrm{min}$ \\
\hline Working fluid & Propylene glycol & --- \\
\hline Concentration of working fluid & 20 & $\%$ by wt \\
\hline Number of pipes & 6 & --- \\
\hline Length of $\mathrm{FHX}$ excavation & 100.0 & $\mathrm{ft}$ \\
\hline Pipe inside diameter & 0.86 & in \\
\hline Pipe outside diameter & 1.05 & in \\
\hline Pipe thermal conductivity & 0.23 & $\mathrm{Btu} /\left(\mathrm{hr}-\mathrm{ft}-{ }^{\circ} \mathrm{F}\right)$ \\
\hline Number of months to run & 36 & months \\
\hline \multicolumn{3}{|c|}{ Additional horizontal ground heat exchanger (HGHX) input parameters } \\
\hline Number of pipes & 6 & -- \\
\hline Length of HGHX excavation & 200.0 & $\mathrm{ft}$ \\
\hline $\begin{array}{c}\mathrm{FHX} \\
\text { pipe number }\end{array}$ & $\begin{array}{c}\mathrm{FHX} \\
\begin{array}{c}\text { depth below ground } \\
(\mathrm{ft})\end{array}\end{array}$ & $\begin{array}{c}\mathrm{FHX} \\
\text { distance from basement wall (ft) }\end{array}$ \\
\hline Pipe 1 & 7.3 & 1.7 \\
\hline Pipe 2 & 7.4 & 2.5 \\
\hline Pipe 3 & 7.1 & 3.3 \\
\hline Pipe 4 & 6.4 & 3.6 \\
\hline Pipe 5 & 5.5 & 3.7 \\
\hline Pipe 6 & 4.6 & 3.6 \\
\hline $\begin{array}{l}\text { HGHX } \\
\text { pipe number }\end{array}$ & $\begin{array}{c}\text { HGHX } \\
\text { depth below ground } \\
(\mathrm{ft})\end{array}$ & $\begin{array}{c}\text { HGHX } \\
\text { distance between Pipe } 1 \\
\text { and Pipe N (ft) }\end{array}$ \\
\hline Pipe 1 & 6.0 & 0.0 \\
\hline Pipe 2 & 6.0 & 1.3 \\
\hline Pipe 3 & 5.0 & 1 \\
\hline Pipe 4 & 5.0 & 1.6 \\
\hline Pipe 5 & 4.0 & 2 \\
\hline Pipe 6 & 4.0 & 2.3 \\
\hline
\end{tabular}




\subsection{Geographic Range of Feasibility of GSHP Systems Using FHX in the United States}

ORNL had previously demonstrated that an FHX-based GSHP system was feasible for a specific small ultra-high-energy-efficiency house in one climate (Christian and Bonar 2008). In order to investigate the geographic range of feasibility of GSHP systems using FHX in single-family residences in the United States, a small-scale parametric study was performed as part of this project (Cullin et al. 2012).

A one-story house over a full basement with characteristics similar to the original ORNL demonstration house was used as the basis of the study. Two house cases, "high insulation (HI)" and "very high insulation (VHI)," were studied in 17 locations. In all locations the houses were assumed to be on flat terrain, have full basements, and have an FHX that encircles the entire perimeter of the house. In this preliminary study, EnergyPlus was used to generate the space conditioning load for the one-story house, and HVACSIM+ was used to generate the space conditioning load for the basement space and for simulation of the HVAC and FHX systems. The 2D, finite-volume, numerical model described in Section 3.2 and implemented in HVACSIM+ was used to simulate the FHX (Xing 2010). An iterative technique was used between EnergyPlus and HVACSIM+ so that the total house load (house and basement) successfully converged in each time step.

Hourly simulations were run for each combination of location and insulation level. For cases in which the heat pump EFT deviated above or below the allowable design limits, a $100 \mathrm{ft}$ supplemental horizontal ground heat exchanger was added to the FHX in series and another simulation performed. The EFT design limits for this study were $30.2^{\circ} \mathrm{F}$ for heating and $99.5^{\circ} \mathrm{F}$ for cooling, with a working fluid of $10 \%$ propylene glycol by weight in water.

From among the 34 cases, there were four cases (Billings HI, Chicago HI, Minneapolis HI, Minneapolis VHI) where EFT deviated below the minimum constraint, and four cases (Houston HI, Phoenix HI, Phoenix VHI, Tallahassee HI) where EFT deviated above the maximum constraint. After adding a $100 \mathrm{ft}$ supplemental horizontal ground heat exchanger, seven or the eight cases had EFT within allowable design limits, leaving only one case (Minneapolis HI) where EFT deviated below the minimum constraint.

This preliminary analysis was used to construct Figure 3.10, which is a map of the United States showing where GSHP systems using FHX in single-family residences appear to be feasible. There are three zones of feasibility: not recommended, marginal, and feasible. Since the high-insulation cases represent current recommended best practice, those results were used to construct the map. A map using the VHI results would show even greater geographic feasibility. The "not recommended" zone indicates locations (such as Minneapolis) where FHX cannot be expected to work, even with the addition of a $100 \mathrm{ft}$ supplemental HGHX. The "marginal" zone includes locations that might require a supplemental HGHX (such as Billings and Houston), as well as locations where the heat pump EFTs may be fairly close to the constraints, say,within two degrees Fahrenheit or so. Finally, the "feasible" area contains the locations where FHX may be expected to work without supplement from an HGHX. 


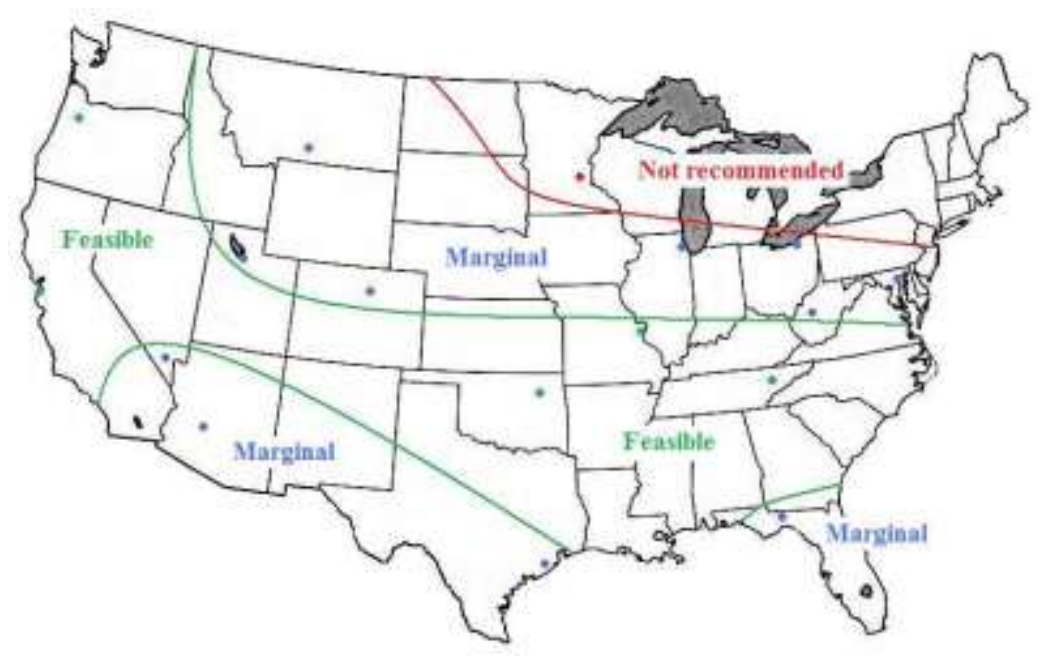

Figure 3.10. Preliminary results for geographic range of feasibility of GSHP systems using FHX in the United States. (Source: Cullin et al. 2012.)

The possibility of soil freezing along the foundation was also investigated. It was found that the presence of the FHX placed in a typical basement excavation, which accommodates reasonable spacing of pipe away from the basement wall, did not add to the freezing of the soil near the foundation, even for the most severe case simulated (Minneapolis HI). Instead, the only cause of soil freezing at the basement foundation wall was weather. There are two noticeable areas of freezing: around the FHX piping, and a uniform depth at the ground surface. While the soil does indeed freeze around the FHX piping, with reasonable pipe spacing from the wall the freezing front never reaches the house foundation. The subfreezing temperatures along the foundation are entirely due to weather effects, as the soil is frozen to a depth of about $3 \mathrm{ft}$ along the entire length of the soil domain. Thus, it can be concluded that the addition of an FHX will most likely not require any additional consideration of protecting the foundation from freezing aside from what would be normal for any typical building in the region. 


\section{DISCUSSION}

Conventional equipment for controlling the temperature and humidity of a building, or supplying hot water and fresh outdoor air, must exchange energy (or heat) with the building's outdoor environment. Equipment using the ground as a heat source and heat sink consumes less non-renewable energy (electricity and fossil fuels) because the earth is cooler than outdoor air in summer and warmer in winter. The most important barrier to rapid growth of the GSHP industry is high first cost of GSHP systems to consumers (Hughes 2008).

The most common GSHP system utilizes a closed-loop ground heat exchanger. This type of GSHP system can be used almost anywhere. There is reason to believe that reducing the cost of closed-loop systems is the best strategy for maximizing energy savings achieved with GSHP technology. The cost premium of closed-loop GSHP systems over conventional space conditioning and water heating systems is primarily associated with drilling boreholes or excavating trenches, installing vertical or horizontal ground heat exchangers, and backfilling excavations.

This project investigates reducing the cost of horizontal closed-loop ground heat exchangers through the use of construction excavations augmented when necessary with supplemental trenches. This approach applies only to new construction of residential and light commercial buildings or additions to such buildings. In general, construction excavations may include the overcut around the basement walls, below the basement floor, utility trenches (for buried water, sewer and power), and trenches for draining the foundation footers. In the business-as-usual scenario these construction excavations are not used for the horizontal ground heat exchanger (HGHX); instead the HGHX is installed entirely in trenches dug specifically for that purpose. The potential cost savings comes from using the construction excavations for the installation of ground heat exchangers to the extent possible and thereby reducing the length of trench that must be dug and backfilled. When construction excavations are used for double duty, adequate spacing between the HGHX and utility pipes is of course required, but simple guidance on this issue is expected to suffice.

The term foundation heat exchanger (FHX) has been coined to refer exclusively to ground heat exchanger installed in the overcut around basement walls. The primary technical challenge in this project was the development and validation of energy performance models and design tools for FHX. In terms of performance modeling and design, ground heat exchangers in utility and footer drain trenches are no different than conventional HGHX in conventional trenches, and models and design tools for HGHX already exist.

Ground heat exchangers installed below the basement floor were not addressed. Project resources were insufficient to address both FHX and sub-floor systems, and it was important to tackle the greatest technical challenge first. Since the sub-floor case has very simple geometry and boundary conditions, the project team felt confident that this capability could be added to the models and design tools later. As it turned out, the computationally efficient performance model developed by this project is able to model sub-floor systems, though this capability has not yet been validated against measured data.

This project developed and validated energy performance models and design tools so that FHX or hybrid FHX/HGHX systems can be engineered with confidence, enabling this technology to be applied in residential and light commercial buildings. The energy performance models developed and validated here also address and solve another problem, the longstanding inadequacy in the way ground-building thermal interaction is represented in building energy models, whether or not there is a ground heat exchanger nearby. 
Two side-by-side, three-level, unoccupied research houses with walkout basements, identical 3,700 $\mathrm{ft}^{2}$ floor plans, and hybrid FHX/HGHX systems were constructed to provide validation data sets for the energy performance models and design tools for hybrid FHX/HGHX systems developed as part of the project. In these unoccupied research houses, human impact on energy use is simulated to match the national average, with showers, lights, ovens, washers, and other energy-consuming equipment turned on and off at exactly the same times. The ground heat exchangers in the two houses were intentionally similar to provide experimental redundancy, essentially guaranteeing that experimental data would be available. Validation was based on the House 1 data set primarily because the sizing of the hybrid FHX/HGHX system there (done without an FHX design tool) turned out to be closer to what was needed than at House 2.

The envelopes of both houses are very energy efficient and airtight, with HERS ratings of 44 and 45 respectively. Both houses are mechanically ventilated with energy recovery ventilators with space conditioning provided by WAHPs with 2 ton nominal capacities. For comparison, typically in East Tennessee, a house built to code and having $3,700 \mathrm{ft}^{2}$ of floor space would require a 4 to 5 ton nominal capacity unit for space conditioning. Separate WWHPs with 1.5 ton nominal capacities were used for water heating. Hot water usage is simulated to match the national average ( 54 gallons per day) for houses of this size and having these characteristics. The WAHP and WWHP units are connected to the ground heat exchanger in parallel with each other.

At House 1 the total excavation length for the hybrid FHX/HGHX system is $300 \mathrm{ft}$, including $100 \mathrm{ft}$ of FHX in the overcut around basement walls, $80 \mathrm{ft}$ in utility trenches, and $120 \mathrm{ft}$ in supplemental trenches. Hence $60 \%$ of the excavations used for installation of the ground heat exchanger ( $180 \mathrm{of} 300 \mathrm{ft}$ ) were required anyway to construct the home. At House 2 the total excavation is $360 \mathrm{ft}$ and there is $100 \mathrm{ft}$ of FHX in the overcut around basement walls, $80 \mathrm{ft}$ in utility trenches, and $180 \mathrm{ft}$ in supplemental trenches, so $50 \%$ is in construction excavations. There are six pipes in all excavations, meaning three parallel circuits taking the working fluid out and back. All circuit pipes are $3 / 4$ inch nominal diameter high density polyethylene. The multiple instances of FHX in basement wall overcuts and HGHX in utility or supplemental trenches are all connected in series. The working fluid is $20 \%$ by weight propylene glycol in water.

Data was collected at both houses and stored using Campbell Scientific Model CR3000 micro-loggers and retrieved remotely over dedicated telephone lines during January through November 2010. In general the data is measured at a rapid scan rate with averages logged at 15 minute intervals, but some channels were logged at intervals as short as 1 minute, as necessary. Measured equipment performance at houses 1 and 2 included WAHP heating season COPs of 3.6 and 3.6, WAHP cooling season COPs of 4.2 and 4.1, and WWHP annual COPs of 3.1 and 2.6. Annual maximum and minimum heat pump EFTs measured at houses 1 and 2 were $93.2^{\circ} \mathrm{F}$ and $33.4^{\circ} \mathrm{F}$, and $90.3^{\circ} \mathrm{F}$ and $33.7^{\circ} \mathrm{F}$, respectively. The full 15 minute interval data set from House 1 was used to validate the energy performance models and design tool.

Model and design tool development proceeded in parallel with construction, installing instrumentation, and monitoring the houses for a year. Several detailed numerical models for FHX were developed as part of the project. Essentially the project team was searching for an energy performance model accurate enough to achieve project objectives while also having sufficient computational efficiency for practical use in EnergyPlus. A 3D, dual-coordinate-system (DCS), finite-volume model satisfied these criteria and was included in the October 2011 EnergyPlus Version 7 public release after being validated against the measured data. EnergyPlus using this model is capable of completing annual simulations of an FHX thermally coupled to a basement in less than two minutes on a modern PC. As an extra bonus, the DCS model can simulate FHX installed below the basement floor, but this capability has not been validated with measured data. 
A practical design tool for sizing pure FHX or hybrid FHX/HGHX systems was also developed and implemented in Excel using Visual Basic for Applications. Using the design tool, sizing the FHX or FHX/HGHX for a residential application can be accomplished in approximately 5 minutes. Compared to one of the numerical models, the design tool was found to oversize the ground heat exchanger by 17 to $20 \%$ in five of six benchmarking locations, and by $29 \%$ in the remaining location. The design tool oversized the hybrid FHX/HGHX system at House 1 by 23\%. Given the inherent uncertainties in design inputs such as building loads and soil thermal properties, this level of accuracy in a simplified FHX design method is acceptable.

One of the numerical models was used to investigate the geographic range of technical feasibility of FHX systems. For a small well-insulated home with 1,600 sf on the first floor, a full basement beneath, and on level terrain, with FHX on all four basement walls, the preliminary analysis indicated that pure FHX systems were technically feasible for new construction in nearly half the United States. Although not investigated, hybrid FHX/HGHX systems should have some level of installed cost savings over conventional HGHX systems in almost any residential or light commercial new construction project involving significant excavation.

Preliminary estimates indicate that when implemented at scale by a production builder, ground heat exchanger in construction excavations (FHX in overcut around basement or HGHX in utility trenches) may be feasible at $\$ 1,000$ per ton. That compares with traditional vertical-loop and six-pipe-per-virgintrench HGHX systems that typically are installed in East Tennessee at $\$ 3,000$ per ton and $\$ 2,250$ per ton, respectively. If these values are correct, hybrid systems would warrant consideration even when use of construction excavations exclusively is not feasible. For example, a 3-ton hybrid FHX/HGHX ground heat exchanger application where construction excavations are adequate for two-thirds of the load would cost $\$ 4,250(2 \times \$ 1000+\$ 2,250)$ compared to $\$ 6,750$ (3 x $\$ 2,250)$ for pure HGHX in virgin trench. The actual cost of a particular project may vary depending on drilling/trenching conditions, regional cost variations, underground soil thermal properties and building geometry. Whether cost reductions through use of construction excavations are enough for GSHP systems to gain significantly broader consideration in new construction markets remains to be seen.

In summary, the project has successfully developed and validated performance models and design tools so that FHX or hybrid FHX/HGHX systems can be engineered with confidence, thus enabling the use of construction excavations for ground heat exchangers to be applied on a large scale. Although it is reasonable to assume that significant cost savings should be achievable from reducing supplemental trench length by using construction excavations, this has yet to be proven. Toward that end, the authors recommend the following next steps:

1. Production-basis approaches to implementing FHX or hybrid FHX/HGHX systems should be developed. The materials, products, tools, and installation techniques used for this two-house demonstration leave considerable room for improvement. Better approaches that are fast and foolproof in the hands of site laborers must be invented (e.g., spray a layer of grout onto the trench side walls using a new device akin to those for spraying or blowing insulations; lay prefabricated mats of cross-linked, parallel, reduced-diameter HDPE tubes onto the grout; spray another layer of grout; let the grout set; finish backfill with bulldozer, etc.).

2. Production-basis implementations of FHX or hybrid FHX/HGHX systems should be evaluated in a variety of climates and soil conditions to further validate performance, determine cost, and develop and document the installation standards for double-duty excavations. These projects should include in their scope the field experiments and effort required to add validated capabilities for sub-basementfloor FHX to the EnergyPlus model and Excel-based design tool developed here. 
3. Documentation of any newly developed materials, products, tools, and installation standards should flow into the appropriate industry tomes (e.g., IGSHPA installation manual, ASHRAE HVAC Applications Handbook Chapter 34) to facilitate widespread use. 


\section{REFERENCES}

ASHRAE (American Society of Heating, Refrigeration, and Air Conditioning Professionals). 2011. ASHRAE Handbook of HVAC Applications, chapter 34, table 35, p34.15.

Boudreaux, P.R., and Anthony Gehl. 2011. Wolf Creek Appliance Control and Occupancy Simulation. TVA Milestone Report D 6.1. Oak Ridge National Laboratory.

Briggs, R.S., R.G. Lucas, and T. Taylor. 2003a. Climate Classification for Building Energy Codes and Standards: Part 1 - Development Process, Technical and Symposium Papers, ASHRAE Winter Meeting, Chicago, IL, January, 2003.

Briggs, R.S., R.G. Lucas, and T. Taylor. 2003b. Climate Classification for Building Energy Codes and Standards: Part 2 - Zone Definitions, Maps and Comparisons, Technical and Symposium Papers, ASHRAE Winter Meeting, Chicago, IL, January, 2003.

Christian, J., and J. Bonar. 2008. Building a 40\% Energy Saving House in the Mixed-Humid Climate, ORNL/TM-2008/08, Oak Ridge National Laboratory, Oak Ridge, Tenn.

Code of Federal Regulations. 2010a. Uniform Test Method for Measuring the Energy Consumption of Automatic and Semi-Automatic Clothes Washers. Title 10 part 430, Subpt B, Appendix J1. http://ecfr.gpoaccess.gov/cgi/t/text/textidx?c=ecfr\&sid=6de07a43f47ca869f23b5d2e416ff012\&rgn=di $\mathrm{v} 9 \&$ view $=$ text $\&$ node $=10: 3 \cdot 0 \cdot 1 \cdot 4 \cdot 16 \cdot 2 \cdot 9 \cdot 6.11 \&$ idno $=10$.

Code of Federal Regulations. 2010b. Uniform Test Method for Measuring the Energy Consumption of Electric Refrigerators and Electric Refrigerator-Freezers, Title 10 part 430, Subpt B, Appendix A1. http://ecfr.gpoaccess.gov/cgi/t/text/textidx?c=ecfr\&sid=6de07a43f47ca869f23b5d2e416ff012\&rgn=di v9\&view=text\&node=10:3.0.1.4.16.2.9.6.1\&idno=10.

Cullin, J.R., L. Xing, E. Lee, J.D. Spitler, and D.E. Fisher. 2012. "Feasibility of Foundation Heat Exchangers In Ground Source Heat Pump Systems in the United States." ASHRAE Transactions: submitted for review.

De Montfort University. 2009. Modeler Report for BESTEST Cases GC10a-GC80c Gems3D Version 2.07. Leicester, UK, De Montfort University. http://www.ornl.gov/sci/ees/etsd/btric/groundsource.shtml.

Fan, D., and S.J. Rees. 2011. Three-Dimensional Mesh Generation Tools. Leicester, UK, DeMontfort University. http://www.ornl.gov/sci/ees/etsd/btric/ground-source.shtml.

Fan, D., S.J. Rees, and J.D. Spitler. 2011. Application of Dynamic Thermal Networks to the Modeling of Foundation Heat Exchangers. Building Simulation 2011. Sydney, Australia, IBPSA.

Fantech 2010. Fantech Energy Recovery Ventilator SER Series (Spec Sheet). http://fantech.net/docsresi/411530-ser-series-spec.pdf (Jan. 24, 2012).

He, M., S. J. Rees, and L. Shao. 2011. "Simulation of a Domestic Ground Source Heat Pump System Using a Three-Dimensional Numerical Borehole Heat Exchanger Model." Journal of Building Performance Simulation. 4(2):141-155.

Hendron, R. 2008. Building America Research Benchmark Definition, National Renewable Energy Laboratory, NREL/TP-550-44816. 2008. http://apps1.eere.energy.gov/buildings/publications/pdfs/building_america/44816.pdf.

Hughes, P.J. 2008. Geothermal (Ground-Source) Heat Pumps: Market Status, Barriers to Adoption, and Actions to Overcome Barriers. ORNL/TM-2008/232, Oak Ridge National Laboratory, Oak Ridge, Tenn. 
Im, P., X. Liu, and J. Monk. 2011. “GSHP Value Rising.” Solar Today, pp. 28-31, March 2011.

Kusuda, T., and P. R. Achenbach. 1965. "Earth Temperatures and Thermal Diffusivity at Selected Stations in the United States." ASHRAE Transactions. 71(1): 61-74.

Lee, E. 2011a. Adding Foundation Heat Exchanger Support to EnergyPlus Ground Heat Exchangers. http://www.ornl.gov/sci/ees/etsd/btric/ground-source.shtml.

Lee, E. 2011b. EnergyPlus I /O Reference for PipingSystem: Underground Stillwater, OK. Oklahoma State University. http://www.ornl.gov/sci/ees/etsd/btric/ground-source.shtml.

Lee, E. 2011c. PipingSystem:Underground Simulation (EnergyPlus Engineering Reference Manual). Stillwater, OK, Oklahoma State University. http://www.ornl.gov/sci/ees/etsd/btric/groundsource.shtml.

Lee, E., and L. Xing. 2011. Experimental Validation of Dual Coordinate System (DCS) Ground Heat Transfer Model. Stillwater, OK, Oklahoma State University. http://www.ornl.gov/sci/ees/etsd/btric/ground-source.shtml.

Miller, W., J. Kośny, S. Shrestha, J. Christian, A. Karagiozis, C. Kohler, and D. Dinse. 2010. “Advanced Residential Envelopes for Two Pair of Energy-Saver Homes.” Proceedings of ACEEE Summer Study on Energy Efficiency in Buildings.

Oklahoma State University. 2011. Foundation Heat Exchanger Design Tool Manual. Stillwater, Oklahoma State University. http://www.ornl.gov/sci/ees/etsd/btric/ground-source.shtml.

Rees. S.J. 2011. EnergyPlus Model Documentation. Leicester, UK, De Montfort University. http://www.ornl.gov/sci/ees/etsd/btric/ground-source.shtml.

Rees, S.J., and D. Fan. 2011. Two/three Dimensional FHX Model Validation. Leicester, UK, De Montfort University. http://www.ornl.gov/sci/ees/etsd/btric/ground-source.shtml.

Rees, S.J., J.D. Spitler, and X. Xiao. 2002. "Transient Analysis of Snow-melting System Performance." ASHRAE Transactions 108(2):406-423.

Spitler, J.D., L. Xing, J.R. Cullin, D. E. Fisher, J. A. Shonder, and P. Im. 2010. Residential Ground Source Heat Pump Systems Utilizing Foundation Heat Exchangers. Clima 2010, Antalya, Turkey, REHVA.

Tarnawski, V. R., and W. H. Leong. 1993. "Computer Analysis, Design and Simulation of Horizontal Ground Heat Exchangers.” International Journal of Energy Research 17: 467-477.

Wentzel, E.-L. 2005. Thermal Modeling of Walls, Foundations and Whole Buildings Using Dynamic Thermal Networks. Department of Civil and Environmental Engineering. Goteborg, Chalmers University of Technology. PhD: 220.

Xing, L. 2010. Analytical and Numerical Modeling of Foundation Heat Exchangers. M.S. Thesis, Oklahoma State University, Stillwater, OK, USA.

Xing, L., J.D. Spitler, and J.R. Cullin. 2012. "Modeling of Foundation Heat Exchangers - Comparison of Numerical and Analytical Approaches." Building Simulation: Submitted for review.

Xing, L., J.R. Cullin, J.D. Spitler, D.E. Fisher, and P. Im. 2011. "Foundation Heat Exchangers for Residential Ground Source Heat Pump Systems - Numerical Modeling and Experimental Validation." HVAC\&R Research: In press.

Xing, L., J.D. Spitler, and J. R. Cullin. 2010. "Modeling of Foundation Heat Exchangers." Proceedings of System Simulation in Buildings 2010, Liège, Belgium. December 13-15. 
APPENDIX - LIST AND LOCATION OF SENSORS 
Table A.1. House 1 sensors and locations

\begin{tabular}{|c|c|c|c|}
\hline Sensor & $\begin{array}{c}\text { DAS } \\
\text { Channel }\end{array}$ & Description & Location \\
\hline Thermistor (6) & $1-001$ & Pipe 1 Rain garden In & Sleeve 1, Station 1, Trench floor (5-ft) \\
\hline “ & $1-002$ & Pipe 2 Rain garden In & Sleeve 1, Station 1, Trench floor (5-ft) \\
\hline " & $1-003$ & Pipe 3 Rain garden In & Sleeve 1, Station 1, Trench floor (5-ft) \\
\hline " & $1-004$ & Pipe 1 Rain garden Exit & Sleeve 1, Station 1, Trench wall (1-ft) \\
\hline " & $1-005$ & Pipe 2 Rain garden Exit & Sleeve 1, Station 1, Trench wall (2-ft) \\
\hline$"$ " & $1-006$ & Pipe 3 Rain garden Exit & Sleeve 1, Station 1, Trench wall (3-ft) \\
\hline Thermistor (12) & $2-001$ & Pipe 1 Rain garden In & Sleeve 1, Station 2, Trench floor (5-ft) \\
\hline “ & $2-002$ & Pipe 2 Rain garden In & Sleeve 1, Station 2, Trench floor (5-ft) \\
\hline " & $2-003$ & Pipe 3 Rain garden In & Sleeve 1, Station 2, Trench floor (5-ft) \\
\hline “ & $2-004$ & Pipe 1 Rain garden Exit & Sleeve 1, Station 2, Trench wall (1-ft) \\
\hline “ & $2-005$ & Pipe 2 Rain garden Exit & Sleeve 1, Station 2, Trench wall (2-ft) \\
\hline " & $2-006$ & Pipe 3 Rain garden Exit & Sleeve 1, Station 2, Trench wall (3-ft) \\
\hline " & $2-007$ & Disturbed soil 1-ft depth & Sleeve 1 , Station $2: 2$-ft from pipes attached to trench wall \\
\hline " & $2-008$ & Disturbed soil 2-ft depth & Sleeve 1 , Station $2: 2$-ft from pipes attached to trench wall \\
\hline “ & $2-009$ & Disturbed soil 3-ft depth & Sleeve 1 , Station $2: 2$-ft from pipes attached to trench wall \\
\hline " & $2-010$ & Undisturbed soil 1-ft depth & Sleeve $8: 15-f t$ from East SE wall \\
\hline " & $2-011$ & Undisturbed soil 2-ft depth & Sleeve $8: 15$-ft from East SE wall \\
\hline " & $2-012$ & Undisturbed soil 3-ft depth & Sleeve $8: 15$-ft from East SE wall \\
\hline Thermistor (6) & 4-001 & Pipe 1SW Trench In & Sleeve 2, Station 4, Trench floor (5-ft) \\
\hline “ & 4-002 & Pipe 2 SW Trench In & Sleeve 2, Station 4, Trench floor (5-ft) \\
\hline$"$ " & 4-003 & Pipe 3 SW Trench In & Sleeve 2, Station 4, Trench floor (5-ft) \\
\hline " & $4-004$ & Pipe 1SW Trench Exit & Sleeve 2, Station 4, Trench wall (1-ft) \\
\hline “ & $4-005$ & Pipe 2 SW Trench Exit & Sleeve 2, Station 4, Trench wall (2-ft) \\
\hline " & 4-006 & Pipe 3 SW Trench Exit & Sleeve 2, Station 4, Trench wall (3-ft) \\
\hline Thermistor (9) & $5-001$ & Pipe 1 WNW FHX Wall In & Sleeve 3, Station 5 : Floor (5-ft depth) \\
\hline “ & $5-002$ & Pipe 2 WNW FHX Wall In & Sleeve 3, Station 5 : Floor (5-ft depth) \\
\hline " & $5-003$ & Pipe 3 WNW FHX Wall In & Sleeve 3, Station 5 : Floor (5-ft depth) \\
\hline " & $5-004$ & Pipe 1 WNW FHX Wall Exit & Sleeve 3, Station 5 : Wall (3-ft depth) \\
\hline “ & $5-005$ & Pipe 2 WNW FHX Wall Exit & Sleeve 3, Station 5 : Wall (4-ft depth) \\
\hline " & $5-006$ & Pipe 3 WNW FHX Wall Exit & Sleeve 3, Station 5: Wall (5-ft depth) \\
\hline$"$ " & $5-007$ & Undisturbed soil 1-ft depth & Sleeve 3 , Station $5: 15$-ft from West FHX wall \\
\hline$"$ & $5-008$ & Undisturbed soil 2-ft depth & Sleeve 3 , Station 5 : 15 -ft from West FHX wall \\
\hline " & $5-009$ & Undisturbed soil 3-ft depth & Sleeve 3 , Station 5 : 15 -ft from West FHX wall \\
\hline Thermistor (11), & $6-001$ & Pipe 1 NNW FHX Wall In & Sleeve 3, Station 6: Floor (5-ft), FHX 4-ft \\
\hline “ & $6-002$ & Pipe 2 NNW FHX Wall In & Sleeve 3, Station 6 : Floor (5-ft), FHX 3-ft \\
\hline " & $6-003$ & Pipe 3 NNW FHX Wall In & Sleeve 3, Station 6: Floor (5-ft), FHX 2-ft \\
\hline “ & $6-004$ & Pipe 1 NNW FHX Wall Exit & Sleeve 3, Station 6 : Trench Wall (1-ft) \\
\hline " & $6-005$ & Pipe 2 NNW FHX Wall Exit & Sleeve 3, Station 6 : Trench Wall (2-ft) \\
\hline " & $6-006$ & Pipe 3 NNW FHX Wall Exit & Sleeve 3, Station 6 : Trench Wall (3-ft) \\
\hline " & $6-007$ & Disturbed soil 1-ft depth & Sleeve 3, Station 6: 2-ft from FHX wall \\
\hline " & $6-008$ & Disturbed soil 3-ft depth & Sleeve 3, Station 6: 2-ft from FHX wall \\
\hline " & $6-009$ & Fiberglass Insulation & Sleeve 4, Station 6: 1-ft below ground level \\
\hline “ & $6-010$ & Fiberglass Insulation & Sleeve 4, Station 6: 4-ft below ground level \\
\hline " & $6-011$ & Fiberglass Insulation & Sleeve 4, Station 6: 7-ft below ground level \\
\hline HFT & $6-012$ & Wall flux \#501 & Sleeve 4, Station 6: 1-ft below ground level \\
\hline HFT & $6-013$ & Wall flux \#502 & Sleeve 4, Station 6: 4-ft below ground level \\
\hline HFT & $6-014$ & Wall flux \#504 & Sleeve 4, Station 6: 7-ft below ground level \\
\hline
\end{tabular}


Table A.1 (continued). House 1 sensors and locations

\begin{tabular}{|c|c|c|c|}
\hline Sensor & $\begin{array}{c}\text { DAS } \\
\text { Channel }\end{array}$ & Description & Location \\
\hline Thermistor (11) & $7-001$ & Pipe $1 \mathrm{~N}$ mid- FHX Wall In & Sleeve 4, Station 7: Floor (5-ft), FHX 4-ft \\
\hline “ & 7-002 & Pipe $2 \mathrm{~N}$ mid- FHX Wall In & Sleeve 4, Station 7: Floor (5-ft), FHX 3-ft \\
\hline " & $7-003$ & Pipe $3 \mathrm{~N}$ mid- FHX Wall In & Sleeve 4, Station 7: Floor (5-ft), FHX 2-ft \\
\hline " & $7-004$ & Pipe $1 \mathrm{~N}$ mid- FHX Wall Exit & Sleeve 4, Station 7 : Trench Wall (1-ft) \\
\hline$"$ " & $7-005$ & Pipe $2 \mathrm{~N}$ mid- FHX Wall Exit & Sleeve 4, Station 7 : Trench Wall (2-ft) \\
\hline “ & 7-006 & Pipe $3 \mathrm{~N}$ mid- FHX Wall Exit & Sleeve 4, Station 7 : Trench Wall (3-ft) \\
\hline " & $7-007$ & Disturbed soil 1-ft depth & Sleeve 4, Station 7 : 2-ft from FHX wall \\
\hline " & 7-008 & Disturbed soil 3-ft depth & Sleeve 4, Station 7: 2-ft from FHX wall \\
\hline " & 7-009 & Fiberglass Insulation & Sleeve 4, Station 7: 1-ft below ground level \\
\hline " & $7-010$ & Fiberglass Insulation & Sleeve 4, Station 7: 4-ft below ground level \\
\hline " & 7-011 & Fiberglass Insulation & Sleeve 4, Station 7: 7-ft below ground level \\
\hline HFT & 7-012 & Wall flux \#505 & Sleeve 4, Station 7: 1-ft below ground level \\
\hline HFT & 7-013 & Wall flux \#508 & Sleeve 4, Station 7: 4-ft below ground level \\
\hline HFT & 7-014 & Wall flux \#511 & Sleeve 4, Station 7: 7-ft below ground level \\
\hline Thermistor (6) & $8-001$ & Pipe 1 NNE FHX Wall In & Sleeve 7, Station 8, Floor (5-ft), FHX 2-ft \\
\hline “ & 8-002 & Pipe 2 NNE FHX Wall In & Sleeve 7, Station 8, Floor (5-ft), FHX 3-ft \\
\hline “ & $8-003$ & Pipe 3 NNE FHX Wall In & Sleeve 7, Station 8, Floor (5-ft), FHX 4-ft \\
\hline " & 8-004 & Pipe 1 NNE FHX Wall Exit & Sleeve 7, Station 8, Trench wall (1-ft) \\
\hline " & 8-005 & Pipe 2 NNE FHX Wall Exit & Sleeve 7 , Station 8 , Trench wall (2-ft) \\
\hline$"$ & $8-006$ & Pipe 3 NNE FHX Wall Exit & Sleeve 7 , Station 8 , Trench wall (3-ft) \\
\hline Thermistor (6) & $9-001$ & Pipe 1 NE Trench In & Sleeve 7, Station 9, Trench floor (5-ft) \\
\hline “ & $9-002$ & Pipe 2 NE Trench In & Sleeve 7, Station 9, Trench floor (5-ft) \\
\hline “ & 9-003 & Pipe 3 NE Trench In & Sleeve 7, Station 9, Trench floor (5-ft) \\
\hline$"$ & $9-004$ & Pipe 1 NE Trench Exit & Sleeve 7, Station 9, Trench wall (1-ft) \\
\hline " & $9-005$ & Pipe 2 NE Trench Exit & Sleeve 7, Station 9, Trench wall (2-ft) \\
\hline " & $9-006$ & Pipe 3 NE Trench Exit & Sleeve 7, Station 9, Trench wall (3-ft) \\
\hline Thermistor (6) & $10-001$ & Pipe 1 NE Trench In & Sleeve 7, Station 10, Trench floor (5-ft) (end of trench) \\
\hline “ & $10-002$ & Pipe 2 NE Trench In & Sleeve 7 , Station 10, Trench floor (5-ft) (end of trench) \\
\hline " & $10-003$ & Pipe 3 NE Trench In & Sleeve 7 , Station 10, Trench floor (5-ft) (end of trench) \\
\hline " & $10-004$ & Pipe 1 NE Trench Exit & Sleeve 7, Station 10, Trench wall (1-ft) (end of trench) \\
\hline " & $10-005$ & Pipe 2 NE Trench Exit & Sleeve 7, Station 10, Trench wall (2-ft) (end of trench) \\
\hline “ & $10-006$ & Pipe 3 NE Trench Exit & Sleeve 7 , Station 10, Trench wall (3-ft) (end of trench) \\
\hline
\end{tabular}


Table A.2. House 2 sensors and locations

\begin{tabular}{|c|c|c|c|}
\hline Sensor & $\begin{array}{c}\text { DAS } \\
\text { Channel }\end{array}$ & Description & Location \\
\hline Thermistor (6) & $1-001$ & Pipe 1 Rain garden In & Sleeve A, Station 1, Trench floor (5-ft) \\
\hline “ & $1-002$ & Pipe 2 Rain garden In & Sleeve A, Station 1, Trench floor (5-ft) \\
\hline " & $1-003$ & Pipe 3 Rain garden In & Sleeve A, Station 1, Trench floor (5-ft) \\
\hline " & $1-004$ & Pipe 1 Rain garden Exit & Sleeve A, Station 1, Trench wall (1-ft) \\
\hline " & $1-005$ & Pipe 2 Rain garden Exit & Sleeve A, Station 1, Trench wall (2-ft) \\
\hline “ & $1-006$ & Pipe 3 Rain garden Exit & Sleeve A, Station 1, Trench wall (3-ft) \\
\hline Thermistor (12) & $2-001$ & Pipe 1 Rain garden In & Sleeve A, Station 2, Trench floor (5-ft) \\
\hline " & $2-002$ & Pipe 2 Rain garden In & Sleeve A, Station 2, Trench floor (5-ft) \\
\hline " & $2-003$ & Pipe 3 Rain garden In & Sleeve A, Station 2, Trench floor (5-ft) \\
\hline " & $2-004$ & Pipe 1 Rain garden Exit & Sleeve A, Station 2, Trench floor (3-ft) \\
\hline " & $2-005$ & Pipe 2 Rain garden Exit & Sleeve A, Station 2, Trench floor (3-ft) \\
\hline “ & 2-006 & Pipe 3 Rain garden Exit & Sleeve A, Station 2, Trench floor (3-ft) \\
\hline " & 2-007 & Disturbed soil 1-ft depth & Sleeve A, Station 2 : 4-ft from pipes measures \\
\hline " & $2-008$ & Disturbed soil 2-ft depth & Sleeve A, Station 2: 4-ft from pipe measures \\
\hline " & 2-009 & Disturbed soil 3-ft depth & Sleeve A, Station 2 : 4-ft from pipe measures \\
\hline " & $2-010$ & Undisturbed soil 1-ft depth & Sleeve $3: 15-\mathrm{ft}$ from ESouth wall \\
\hline " & $2-011$ & Undisturbed soil 2-ft depth & Sleeve $3: 15$-ft from ESouth wall \\
\hline " & $2-012$ & Undisturbed soil 3-ft depth & Sleeve $3: 15$-ft from ESouth wall \\
\hline Thermistor (6) & 4-001 & Pipe 1 NW Trench In & Sleeve 1, Station 4, Trench Wall (1-ft) \\
\hline “ & 4-002 & Pipe 2 NW Trench In & Sleeve 1, Station 4, Trench Wall (2-ft) \\
\hline " & 4-003 & Pipe 3 NW Trench In & Sleeve 1, Station 4, Trench Wall (3-ft) \\
\hline " & 4-004 & Pipe $1 \mathrm{NW}$ Trench Exit & Sleeve 1, Station 4 : Floor (5-ft depth) \\
\hline " & 4-005 & Pipe 2 NW Trench Exit & Sleeve 1, Station 4 : Floor (5-ft depth) \\
\hline " & 4-006 & Pipe 3 NW Trench Exit & Sleeve 1, Station 4 : Floor (5-ft depth) \\
\hline " & $5-007$ & Undisturbed soil 1-ft depth & Sleeve 2 , Station $6: 15$-ft from West SW FHX wall \\
\hline " & $5-008$ & Undisturbed soil 2-ft depth & Sleeve 2 , Station $6: 15$-ft from West SW FHX wall \\
\hline “ & $5-009$ & Undisturbed soil 3-ft depth & Sleeve 2, Station $6: 15$-ft from West SW FHX wall \\
\hline Thermistor (6) & $5-001$ & Pipe 1 WSW FHX Wall In & Sleeve 2, Station 5 : Trench Wall (1-ft) \\
\hline$"$ & $5-002$ & Pipe 2 WSW FHX Wall In & Sleeve 2, Station 5 : Trench Wall (2-ft) \\
\hline " & $5-003$ & Pipe 3 WSW FHX Wall In & Sleeve 2, Station 5 : Trench Wall (3-ft) \\
\hline " & $5-004$ & Pipe 1 WSW FHX Wall Exit & Sleeve 2, Station 5 : Floor (5-ft), FHX 4-ft \\
\hline " & $5-005$ & Pipe 2 WSW FHX Wall Exit & Sleeve 2, Station 5 : Floor (5-ft), FHX 3-ft \\
\hline " & $5-006$ & Pipe 3 WSW FHX Wall Exit & Sleeve 2, Station 5 : Floor (5-ft), FHX 2-ft \\
\hline
\end{tabular}


Table A.2 (continued). House 2 sensors and locations

\begin{tabular}{|c|c|c|c|}
\hline Sensor & $\begin{array}{c}\text { DAS } \\
\text { Channel }\end{array}$ & Description & Location \\
\hline $\begin{array}{c}\text { Thermistor (11), } \\
\text { HFT (3) }\end{array}$ & $6-001$ & Pipe 1 NNW FHX Wall In & Sleeve 1, Station 6: Trench Wall (1-ft) \\
\hline " & $6-002$ & Pipe 2 NNW FHX Wall In & Sleeve 1, Station 6: Trench Wall (2-ft) \\
\hline “ & $6-003$ & Pipe 3 NNW FHX Wall In & Sleeve 1, Station 6: Trench Wall (3-ft) \\
\hline " & $6-004$ & Pipe 1 NNW FHX Wall Exit & Sleeve 1, Station 6: Floor (5-ft), FHX 4-ft \\
\hline " & $6-005$ & Pipe 2 NNW FHX Wall Exit & Sleeve 1, Station 6: Floor (5-ft), FHX 3-ft \\
\hline " & $6-006$ & Pipe 3 NNW FHX Wall Exit & Sleeve 1, Station 6: Floor (5-ft), FHX 2-ft \\
\hline " & $6-007$ & Disturbed soil 1-ft depth & Sleeve 1, Station 6: 2-ft from FHX wall \\
\hline " & $6-008$ & Disturbed soil 3-ft depth & Sleeve 1, Station 6: 2-ft from FHX wall \\
\hline " & 6-009 (high) & Fiberglass Insulation & Sleeve 1, Station 6: 1-ft below ground level \\
\hline " & 6-010 (mid) & Fiberglass Insulation & Sleeve 1, Station 6: 4-ft below ground level \\
\hline " & 6-011 (low) & Fiberglass Insulation & Sleeve 1, Station 6: 7-ft below ground level \\
\hline HFT & 6-012 (high) & Wall flux \# 507 & Sleeve 1, Station 6: 1-ft below ground level \\
\hline HFT & $6-013$ (mid) & Wall flux \# 513 & Sleeve 1, Station 6: 4-ft below ground level \\
\hline HFT & 6-014 (low) & Wall flux \# 519 & Sleeve 1, Station 6: 7-ft below ground level \\
\hline $\begin{array}{c}\text { Thermistor (11), } \\
\text { HFT (3) }\end{array}$ & $7-001$ & Pipe $1 \mathrm{~N}$ mid-FHX Wall In & Sleeve 6, Station 7 : Trench Wall (1-ft) \\
\hline " & $7-002$ & Pipe $2 \mathrm{~N}$ mid-FHX Wall In & Sleeve 6, Station 7 : Trench Wall (2-ft) \\
\hline " & $7-003$ & Pipe $3 \mathrm{~N}$ mid-FHX Wall In & Sleeve 6, Station 7 : Trench Wall (3-ft) \\
\hline " & $7-004$ & Pipe $1 \mathrm{~N}$ mid-FHX Wall Exit & Sleeve 6, Station 7 : Floor (5-ft), FHX 4-ft \\
\hline “ & $7-005$ & Pipe $2 \mathrm{~N}$ mid-FHX Wall Exit & Sleeve 6, Station 7 : Floor (5-ft), FHX 3-ft \\
\hline " & $7-006$ & Pipe $3 \mathrm{~N}$ mid-FHX Wall Exit & Sleeve 6, Station 7: Floor (5-ft), FHX 2-ft \\
\hline “ & 7-007 & Disturbed soil 1-ft depth & Sleeve 6, Station 7: 2-ft from FHX wall \\
\hline$"$ & $7-008$ & Disturbed soil 3-ft depth & Sleeve 6, Station 7 : 2-ft from FHX wall \\
\hline " & 7-009 (high) & Fiberglass Insulation & Sleeve 6, Station 7: 1-ft below ground level \\
\hline " & 7-010 (mid) & Fiberglass Insulation & Sleeve 6, Station 7: 4-ft below ground level \\
\hline “ & 7-011 (low) & Fiberglass Insulation & Sleeve 6, Station 7: 7-ft below ground level \\
\hline HFT & 7-012 (high) & Wall flux \# 514 & Sleeve 6, Station 7: 1-ft below ground level \\
\hline HFT & $7-013$ (mid) & Wall flux \# 516 & Sleeve 6, Station 7: 4-ft below ground level \\
\hline HFT & 7-014 (low) & Wall flux \# 510 & Sleeve 6, Station 7: 7-ft below ground level \\
\hline Thermistor (6) & $8-001$ & Pipe 1 NNE FHX Wall In & Sleeve 7, Station 8, Trench Wall (1-ft) \\
\hline " & 8-002 & Pipe 2 NNE FHX Wall In & Sleeve 7, Station 8, Trench Wall (2-ft) \\
\hline " & $8-003$ & Pipe 3 NNE FHX Wall In & Sleeve 7, Station 8, Trench Wall (3-ft) \\
\hline " & 8-004 & Pipe 1 NNE FHX Wall Exit & Sleeve 7, Station 8, Floor (5-ft), FHX 4-ft \\
\hline " & $8-005$ & Pipe 2 NNE FHX Wall Exit & Sleeve 7, Station 8, Floor (5-ft), FHX 3-ft \\
\hline " & $8-006$ & Pipe 3 NNE FHX Wall Exit & Sleeve 7, Station 8, Floor (5-ft), FHX 2-ft \\
\hline Thermistor (6) & $9-001$ & Pipe 1 NE Trench In & Sleeve 7, Station 9, Trench Wall (1-ft) \\
\hline " & $9-002$ & Pipe 2 NE Trench In & Sleeve 7, Station 9, Trench Wall (2-ft) \\
\hline " & $9-003$ & Pipe 3 NE Trench In & Sleeve 7, Station 9, Trench Wall (3-ft) \\
\hline “ & 9-004 & Pipe 1 NE Trench Exit & Sleeve 7, Station 9 Floor (5-ft depth) \\
\hline “ & $9-005$ & Pipe 2 NE Trench Exit & Sleeve 7, Station 9, Floor (5-ft depth) \\
\hline " & $9-006$ & Pipe 3 NE Trench Exit & Sleeve 7, Station 9, Floor (5-ft depth) \\
\hline Thermistor (6) & $10-001$ & Pipe 1 NE Trench End & Sleeve 7 , Station 10, Tench (1-ft ) (end of trench) \\
\hline " & $10-002$ & Pipe 2 NE Trench End & Sleeve 7 , Station 10, Tench (2-ft ) (end of trench) \\
\hline " & $10-003$ & Pipe 3 NE Trench End & Sleeve 7 , Station 10, Tench (3-ft ) (end of trench) \\
\hline
\end{tabular}

